III.

\title{
LIST OF THE BIRDS COLLECTED BY ERNST MAYR.
}

BY ERNST HARTERT.

\section{Gymnocorvus tristis (Less. \& Garnot).}

This common bird which is spread over New Guinea, where it is also common on the Hydrographer Mountains, was found in various stages of coloration in Arfak on the hills near Siwi, 7.v.1928, at Wondiwoi (Wandammen) $1900 \mathrm{~m}$. high, at Hollandia and Ifaar on Lake Sentani (south of Hollandia). The Iris is marked light blue (juv.) and brown (med.). In the stomach fruits.

(According to the researches of Sherborn the above name was published first. For a long time this Raven was known as Gymnocorvus senex.)

\section{Ailuroedus melanotis arfakianus Meyer.}

Ailuroedus arfakianus A. B. Meyer, Sitzungsber. Akad. Wiss. Wien, xlix, p. 82 (Arfak Mts.).

This form was found to be not rare at Siwi (Arfak) and Ditchi (1200 m.).

"Iris braun, hellbraun, dunkelbraun. Schnabel weissgrau, hellhornfarben. Füsse grau."

Of great interest are two young birds from Siwi, shot 19.iv . and 15.v.1928. They have thick brownish white downy plumage on the underside in which a feather of the adult is just appearing. The head is thickly covered with rufousbrown down, the underside with a mesoptile of soft down-like plumage of a brownish-grey, darker basally, sides of body browner. Interscapulium and wings already green as feathers in adult. "Iris grau, Schnabel hell, Füsse bleigrau." Wings of sexed males 163, 167, 160-others moulting. A female is evidently shorter in the wing, but the latter is too much worn to give a measurement.

In 1895 Lord Rothschild described, from a specimen bought from Renesse van Duivenbode a skin without a label, but said to be from Jobi, as "Ailuroedus jobiensis."

Later on he considered this name to be a synonym, and I concurred in this opinion. I am, however, now convinced that it is not a synonym. Besides the type we have now three other specimens of various native preparations which differ from the eight adult skins sent by Dr. Ernst Mayr, in having the spots on the head not pure white or very nearly white but brown, and much larger, and quite brown (instead of whitish) centres to the feathers of the hindneck and upper interscapulium ; moreover, in the type of jobiensis and one of our other specimens the black of the throat reaches further down to the breast. These specimens have no indication of locality, but I now consider it possible, that they are from another locality, though perhaps not from Jobi. These birds approach Stresemann's guttaticollis from the Hunsteinspitze, Sepik Region. 


\section{Ailuroedus buccoides geislerorum A. B. Meyer.}

Ailuroedus geislerorum A. B. Meyer, Abh. Mus. Dresden, iii, 4, p. 12 (1891-Astrolabe Bay and Huongulf).

A series of adults from Hollandia is fairly uniform, though the size of the black spots on the underside varies somewhat. A juvenile shot 11.x.1928 (No. 2813) has the crown of the head much darker with a median stripe of yellowish brown spots. The iris of the adults is red, in one case brownish red, that of the young bird is described as grey.

(There is also a juvenile female from Momi, on the east coast of the Arfak Peninsula, 25.vi.1928 (iris not described), with the crown still darker brown, the median line of light spots indistinct. This must belong to either $A$. b. oorti or A. b. buccoides !)

A female from Ifaar, 24.ix.1928 (apparently adult), has the crown much lighter and more rufous, differing from the head in Ai. buccoides molestus $\mathrm{R}$. \& $\mathrm{H}$. (Nov. Zool. xxxv, p. 59, 1929) in being less rufous and with a greenish wash along the centre; more material would be necessary to say what the meaning of this coloration is. The wings of adult males vary from about 130 to 136 , females 130 or $129 \mathrm{~mm}$.

\section{Chlamydera cerviniventris cerviniventris Gould.}

Chlamydera cerviniventris Gould, Proc. Zool. Soc. London, part xviii, p. 201 (Cape York. This part, according to Sclater, was only published in 1851, though ealled 1850). (An abridged description (without measurements) appeared in Jardine's Contr. Orn. 1850, p. 106 (err. 160 !), without locality. This has priority over the appearance in public of the description in the Proceedings, according to Mathews.)

This species which inhabits the Cape York Peninsula of North Queensland and Eastern New Guinea, was hitherto only known as far west as Hatzfeldhafen, but was found common at Ifaar, on Sentani Lake south of the Cyclops Mountains near Hollandia. Mayr collected 28 specimens during the second half of September. The iris is marked as "braun " and "dunkelbraun " in one case "bleich graubräunlich." The testes were mostly found well enlarged, eggs of females very large, some laying.

The wings measure up to 150 , exceptionally 153 , the females as a rule 4 to $5 \mathrm{~mm}$. shorter. Specimens from S.E. Papua and Cape York are usually smaller, wings not over 150 , or 151 , but some Ifaar males have also 145 and 146,148 . There is thus too much variation in the size to claim the Ifaar birds as a larger subspecies.

A. B. Meyer, in the Abh. Mus. Dresden, vol. v, No. 10, named eggs of this species Chlamydera recondita, Mathews later on ealled specimens from British Papua Chl. cerviniventris nova. Neither of these names is referable exclusively to the Ifaar birds. There is thus a lot to say about the nomenclature of this bird, though Mathews says it has " no technical history," meaning that it has no nomenclatorial history.

By the discovery of this bird on the Sentani Lake its distribution has been extended westwards for about $550 \mathrm{~km}$. 


\section{Xanthomelus aureus (L.).}

Coracias aurea Linnaeus, Syst. Nat. ed. x, p. 108 (1758 - "Asia "! Ex Edwards, pl. 112).

2 ô ad., 3 "우," 1 " ô" in plumage of female and young, from the mountains at Siwi (about $900 \mathrm{~m}$.). The male is not bigger than the females, but it has wide (not narrow) pale yellow shaft-stripes on the scapulars, and this seems to be the difference of the male from the female. The iris of females and young is brown, that of the adult males lemon-yellow. One of the adult males shot 25.iv.1928 is moulting on the crown, lower back and underside, the middle rectrices are not quite fully grown.

o. Wondiwoi (Wandammen Peninsula), 14.vii.1928, has the throat black, the crown and sides down over the ears orange, but back, rump, wings and tail olive-brown ; the scapulars have also wide yellowish shaft-stripes. Though not in adult plumage the testes were large! I believe Wandammen is a new locality.

\section{Amblyornis inornatus inornatus (Schleg.).}

Ptilonorhynchus inornatus Schlegel, Nederl. Tijdschr. Dierkunde, iv, p. 51 (1871-Northern Peninsula, i.e. Arfak or Berau Peninsula of New Guinea. Sexes alike! Ex Rosenberg MS.).

Dr. Mayr sent 23 skins from Siwi, Mountains near Ditschi, Gunong Mundi near Ditschi, $1500 \mathrm{~m}$., and Lehuma, others from Wondiwoi in the Wandammen Peninsula. The iris is marked as brown. The underside is darker, more brownish in the Wondiwoi specimens, but one from Ditschi and some from Lehuma are exactly alike the Wondiwoi ones; the paler birds are perhaps faded, the plumage having been longer worn.

It is strange that older skins collected by Bruijn's hunters near Hatam (Atam), Arfak, have the upperside more rufous, the tail browner, less blackish brown, the freshly collected skins of Mayr having rather dark, almost blackish brown tails. Probably this is due to their having become "foxy," like C. L. Brehm's skins in some instances, because they are such a long time in collections. The sexes are alike, except that the females are very slightly smaller. Wings in males 131-137 mm., in birds marked females 125-132 mm. Weight 105-140 g. All these birds have no sign of a large occipital crest. Salvadori, in his immortal Orn. Pap. ii, p. 667, enumerates 26 skins from Hatam, collected by D'Albertis, Beccari's and Bruijn's hunters, and none of them had a sign of a crest, nor had the types, and therefore they were called inornatus!

It was not before 1895 that there was a mention of crested males from Dutch New Guinea. Then in Bull. B.O. Club, iv, no. xxiii, p. xvii, the late A. B. Meyer described what he called the "hitherto unknown male of Amblyornis inornata," with a large crest! This was then accepted by Sharpe and Lord Rothschild. I too thought this was correct. But is this really correct? The following facts must be considered.

(1) It is very peculiar that among the skins received in Europe from 1871 to 1895 there was not a single crested specimen, in fact the opposite would be more probable, as the native hunters were out for strikingly coloured " beautiful " birds, but might not have sent the uncrested simple brown birds.

(2) Though Lord Rothschild has received since 1895 till now not less than eleven large-crested birds of native preparation, we do not know the exact locality of any of them. In 1895 both Dr. Meyer and the Tring Museum received each a skin said to be from Karon (or Karoon), N.W. of Arfak, on the north 
coast of the Berau Peninsula. They came from Mr. Renesse van Duivenbode, but had of course no label, and this information was merely from hearsay. The skins of the crested males are filled with cocoanut fibre, one with some dried leaves, and they are rough and hard, as if dried over fire. But none of these skins came apparently from Arfak!

(3) Both Dr. Ernst Mayr and Mr. Shaw-Meyer were emphatically told that crested males never occurred in Arfak or thereabouts, and both failed to even see one. Yet somewhere they must be common. Of course we find in the mountains of S.E. New Guinea the very closely allied (but underneath duller and on the upperside less dark) Amblyornis inornatus musgravii, and on the Saruwaged Mountains the also closely allied Ambl. inornatus germanus, but the crested males described above never came from either of these localities, where birds of that preparation never originated.

The question now is :

Are the crested males of which specimens were received (said to be from Karon) after all the males of the $A$. inornatus inornatus, or are they a representative crested form from a different locality? In the latter case they require a new name.

There is still another mystery: from where are the three Amblyornis flavifrons Rothsch.?

There is a rumour that they may occur somewhere inland of the Berau Peninsula, but this requires confirmation. The three skins are rather of the better "Arfak preparation," with "heels" sown together and filled with "kapok." And how are the females? Maybe the females are hardly separable from those of "inornatus." The figure of A. flavifrons in Sharpe's Monograph of the Paradiseidae is, I am sorry to say, very bad. The crest is too reddish orange, and the shape of the crest-feathers is wrong, as they are all long narrow parallel feathers rising at the forehead, not ending all over the crown, as in the figure.

The fact is that the " crested " males of inornatus from the northern part of the "Vogelkop" (Berau Peninsula) have the underside darker, more rufous brown, the sides of the neck darker, and the back and wings deeper rufous, without the olivaceous tinge of the specimens from the Snow and Weylandt Mountains. As I consider the latter to be-for the time being-inseparable from A. i. musgravii, I name the form from Karon

Amblyornis inornatus mayri subsp. nov.

Type : ơ ad., probably Karon ("Karoon "), northern "Vogelkop."

\section{Paradigalla carunculata Less.}

Paradigalla carunculata Lesson, Hist. Nat. Ois. de Paradis, p. 242 (1835-No locality indicated. The Type is a specimen with replaced breast and abdomen).

Dr. Mayr sent a $\hat{\sigma}$ from the mountains near Ditschi 12.vi.1928, and a female from Lehuma, 29.v.1928. Mr. F. Shaw-Meyer obtained a female on the Arfak Mountains in August 1928, at an altitude of 7,000 feet. Mayr described the iris as " dark," bill black, feet grey, Meyer says feet and bill black! Mayr says: "Schnabellappen zitronengelb, am äusseren Rande etwas ziegelfarbig, Unterschnabellappen oben violettblau, unten gelbrot." Meyer : " Upper wattles 
yellowish-green, base of lower mandible bright blue ; a small patch of orangered underneath."

Wing of 0195 , \& $159,160 \mathrm{~mm}$. क weight $170 \mathrm{~g}$.

Evidently this species is only known from the Arfak Peninsula.

\section{Parotia sefilata sefilata (Penn.).}

Paradisea sefilata Pennant in Forster's Zool. Indica, Faunula indica, p. 40 (1781-Ex Daubenton, Pl. Enl. 633. In the text no locality, but at that time only the Arfak form was known).

Dr. Mayr found this species common in the mountains of the Arfak region, at Ditschi and Siwi, and still more so in the mountains of Wondiwoi in the Wandammen Peninsula. I believe it was only known with certainty from Arfak. The fine series of females and males in off-plumage from Wondiwoi are underneath generally more rufous brown than those from the Arfak Mountains, but this is, in my opinion, not geographical variation, but due to their being all in fresh plumage, and some are practically undistinguishable. The iris of both sexes is blue with an outer yellow ring, bill black, feet greyish or blackish brown. Weight ô 175-200, ㅇ 160-185 g.

The young bird in first plumage has rufous red outer and inner edges to the quills and upper wing-coverts.

In the Ibis, 1911, p. 366, Lord Rothschild has treated Parotia lawesi and helenae as subspecies of sefilata. This was criticized by Stresemann in 1923. At first sight lawesi and sefilata look very much the same, but there are greater differences than are at first apparent. $P$. lawesi is throughout much smaller; the tail is not much more than half the length of that of sefilata; in sefilata the frontal tuft of feathers is black-brown with greyish-white tips, in lawesi they are less stiff and snow-white at base, black-brown on tip ; the colour of the glittering nuchal patch and the much deeper and rufous-brown underside of the female of lawesi are insignificant characters. Considering the striking differences of size and headgear of males it is perhaps wisest to accept Stresemann's grouping : $P$. sefilata (Penn.) - P. lawesi lawesi and $P$. lawesi helenae. $-P$. wahnesi.- $P$. carolae carolae, $P$. carolae meeki, $P$. carolae berlepschi, all in accordance with Lord Rothschild 1911, except the first.

Then there is the very peculiar Parotia duivenbodei Rothsch. Two specimens are known, both purchased from plumassiers, the type in the Tring Museum, from Mr. van Renesse van Duivenbode, with 2 plumes, one on each side of the head, one in the Paris Museum, without any plumes on the head, otherwise quite like the type.

\section{Lophorina superba superba (Penn.).}

Paradisea superba Pennant, Forster's Indische Zool., Faunula Indica, p. 40 (1781-Ex Daubenton, Pl. Enl.632. No locality, but hitherto only known from Arfak).

Mayr sent a good series from Siwi and 3 of: 2 f from Wondiwoi in Wandammen. Here too the females are rather more rufous on the underside than the Arfak specimens (Siwi), but one of the Arfak ones is almost indistinguishable! Weight ô $87-105$, 우 $67 \cdot 5-85 \mathrm{~g}$.

(Judging from the males Lord Rothschild identified Grant's feminina (1915) from the Utakwa River with latipennis (1907). Certainly there seemed to be 
no difference between males from the Utakwa, the Weylandt and Rawlinson Mountains, but females from the latter were not known. Judging from two females sent by Dr. Mayr from N.E., formerly German, New Guinea, they are quite different from the females of Weylandt and Snow Mountains, having the crown like minor and being underneath whitish, not rufescent. Therefore feminina would be a good subspecies, differing in the female. This would also be more in accordance with zoogeographical knowledge. Mayr's skins from N.E. Papua have only numbers, no localities, on their preliminary labels, so I cannot yet say if they are from the Rawlinson or Hertzog Mountains. Written November 1929.)

\section{Ptiloris (Craspedophora) magnifica magnifica (Vieill.).}

Falcinellus magnificus Vieillot, Nouv. Dict., nouv. éd., vol. 28, p. 167 and pl. Gf. 3 (1807- "La Nouvelle Guinée ").

This form is widespread from Arfak along the northern coast to apparently Astrolabe Bay, and in the south-eastwards to the Fly River.

Mayr sent adult males and young males in female plumage and one female from Arfak (Siwi, Momi, Warior), Wondiwoi, Hol and Cyclops Mountain.

I don't think it is far wrong to separate the soft feathered Ptiloris (rectius Ptilorhis), type paradisea, from the harsh-feathered Craspedophora, much as I am in favour of few genera.

\section{Drepanornis albertisi albertisi Scl.}

Drepanephorus albertisi Sclater, Nature, viii, pp. 151, 195 (1873-No description, only "long incurved bill" mentioned, no locality).

Drepanornis albertisi Sclater, Proc. Zool. Soc. 1873, pp. 558, 560, plate 47. (Full description, figure, locality Arfak Mountains).

This is another form only known from the Arfak Peninsula.

Dr. Mayr sent 4 adult males and two in juvenile plumages from the mountains above Ditschi and near the Anggi Lakes in the Arfak region.

He also sent an adult female, which seems to belong to this subspecies from Wondiwoi (Wandammen), shot 8.vii.1928.

Weight ô 105-125 g.

\section{Drepanornis bruijnii Oust.}

Drepanornis bruijnii Oustalet, Ann. Sci. nat. ser. 6, ix, article 5 (1880 - Said to live evidently further east than $D$. albertisi, as it was obtained by Bruijn - rectius Bruijn's hunters - between long. $136^{\circ}$ and $137^{\circ}$, in fact I suppose that it came from further east still than $\left.137^{\circ}\right)$. Later specimens from the north coast east of $138^{\circ}$, and from Tana Mera east of Humboldt Bay, came to hand.

Mayr obtained a series at Hol (Humboldt Bay) in August and October, mostly still in moult, but testes of males in some cases greatly enlarged. Therefore, probably, the nesting season will be November. Nest and eggs unknown. larger.

The males in female plumage are exactly like the adult females, only slightly

Weight 4 ô $160 \mathrm{~g}$. 


\section{Seleucides melanoleucus ${ }^{1}$ auripennis Schlüt.}

Seleucides ignotus auripennis Schlüter, Falco, vii, p. 2 (1911-Dallmannshafen).

Mayr found this remarkable bird not rare near Hol in August and again on October 12th. This subspecies was described as more golden yellow on the plumes and smaller. The bright yellow colour of the plumes is, however, very fleeting, and it is doubtful if there is much difference between freshly moulted fresh adult $S$. melanoleucus melanoleucus and auripennis. The dimensions are smaller all round, the bill shorter and slenderer. The wings of 14 adult males measure $165-170 \mathrm{~mm}$., those of the larger race up to $181 \mathrm{~mm}$. The sexual organs were greatly enlarged in October and fairly small in August.

Weight ô $170-200$, ㅇ $160,160 \mathrm{~g}$.

\section{Epimachus fastosus fastosus (Hermann).}

(Epimachus speciosus, Falcinellus striatus auctorum).

Promerops fastosus Hermann, Tab. Aff. Anim. etc. pp. 194, 202 (1783-Ex Montbeillard in Buffon, vi, p. 472, "Grand Promerops à parements frisés," New Guinea. As all specimens used to come from the Arfak Peninsula, I accept Arfak as the typical locality).

Ernst Mayr and Shaw Mayer collected specimens in the mountains near Ditschi and Lehuma, at 2,000 m., more or less. The iris of the male (according to Mayr) is red, according to Mayer reddish orange, that of the female, according to Mayr red-brown, in one case pale brownish red.

All these males have the breast and abdomen nearly black, but with a pronounced brown tint, while all the old trade skins that usually represent this species in collections are underneath more brown, one might say very deep chocolate; I have no doubt that this is due to their being in collections for a long time, all killed in the last century, and one procured by Dr. Guillemard at Arfak is exactly like the other trade skins. This typical form is evidently only found in the Arfak Peninsula (Berau, "Vogelkop ").

Weight $\sigma^{*}$ in full plumage 250-280, 우 160-235 g.

\section{Epimachus fastosus atratus (Rothsch. \& Hart.).}

Falcinellus striatus atratus Rothschild \& Hartert, Nov. Zool. xviii, p. 160 (1911- "Mt. Goliath, at altitudes of not less than 5,000 feet").

Ernst Mayr collected six adult males and a number of females and young males from Wondiwoi in the Wandammen Peninsula; these, to my surprise, are not E. fastosus fastosus, but agree with our E. f. atratus from Mt. Goliath and Mt. Kunupi in the Weylandt Mountains. E. f. atratus is therefore the form of

1 I must reluctantly enter here upon a nomenclatorial explanation, because this species has usually been known under different names. For a long time it has been called alba and nigricans, while Rothschild reverted to ignotus. The name ignotus, however, was only used by Forster in the Latin translation for the "unbekannte Paradiesvogel" and has no nomenclatorial value. Recently Stresemann and others returned to nigricans, but omitted entirely Paradisea melanoleuca Daudin, Traité Elém. et complet d'Orn. ii, p. 278 (1800 - "Waigiu," probably errore, as not yet found there, but Arfak Peninsula). Daudin's name is undisputable, the description : "Noir par devant, blane par derrière, avec douze tiges setacées, courbées, et presque dépourvues de barbes " unmistakable. Nor can Daudin's names be rejected, because in a few cases he used three names ! In fact a number of names from Daudin, such as Circus ranivorus, Otogyps auricularis, Cuncuma vocifer, Polemaëtus bellicosus, Lophoaëtus occipitalis, Helotarsus ecaudatus and others have never been disputed on that account! 
the great central range, called in its various parts Weylandt, Nassau, Orange Range and Snow Mountains in the middle.

$E$. $f$. atratus is a close ally of E. $f$. fastosus but differs in the male being underneath of a deeper black, entirely or almost devoid of the chocolate tinge. The females and young males differ from those of $E$. f. fastosus in their more olivaceous, much less rufescent tails. (There is no difference in fresh specimens in the ornamental side-plumes.)

Weight $\hat{o}$ in full plumage $250,255,255,275,275$, 우 $165,185,210 \mathrm{~g}$.

Epimachus fastosus stresemanni subsp. nov.

The Berlin Museum received from the Sepik Expedition 17 specimens, collected by Dr. Bürgers, of a dark form of $E$. fastosus, agreeing in coloration with $E$. f. atratus. Dr. Stresemann already suggested (p. 34 of his article on Bürgers' ornithological collection) that the Snow Mountains form differed in size from the Schraderberg (Upper Sepik) form and gave careful measurements, showing that the bills ${ }^{1}$ varied from 62 to $66.5 \mathrm{~mm}$. in adult males, wings 210 to 222 , bills 63.5 to 72 in adult females, wings $175-182 \mathrm{~mm}$.

As the wings of adult atratus from Mt. Goliath, the Weylandt Mountains and Wandammen measure only: $\hat{o}$ ad. wings $190,195,196,198,187$, the bills $58-60$, o ad. wings 156 to 170 (if the latter is not a young male), the Schraderberg specimens form clearly a considerably larger subspecies, therefore I propose to name this after my friend Dr. Stresemann. Type ô ad. in the Tring Museum, Schraderberg 13.vi.913, No. 2094 of the collector.]

\section{Astrapia nigra (Gm.).}

Paradisea nigra, Gmelin, Syst. Nat. i, 2, p. 401 (1789-Ex Latham “Gorget Paradise Bird," Gen. Syn. i, p. 478, pl. 20. Latham says that the "Alfoories in Messowal shoot these birds and sell them to the people of Tidore." I don't know where "Messowal "was, but the original locality should be regarded as Arfak).

1 " ô" in "off plumage" from Dohunsehik, Issim valley, 17.vi.1928. "Iris dunkel, Schnabel schwarz, Füsse graubraun." This specimen has a wing of only $176 \mathrm{~mm}$. It is rather blackish, there are only traces of whitish speckles, and the wings have no rufous edges on the outside. Mayr did not find this species in the other collecting stations in Arfak, where it is now probably rare, having been collected there for a long time. It is, however, still found there, as Mr. Shaw Mayer obtained a fine adult male in the Arfak Mountains, $2,300 \mathrm{~m}$. high, 17. viii.1928. This species apparently is found only in the Arfak or Berau Peninsula.

\section{Cicinnurus regius claudii Ogilvie-Grant.}

Cicinnurus regius claudii Ogilvie-Grant, Ibis, Suppl. p. 16 (1915-From the Mimika River eastwards to S.E. New Guinea at least as far as Collingwood Bay, westwards to Misol. Type Mimika River).

A fine series from Momi, collected in June, and two in full moult from 15.iv.1928, but no females, nor nests were found.

This widely spread form has the black spot above the eye rounded, more

1 Measured from forepart of nostrils to tip with a compass. 
or less distorted in skins, if they are not of the very first quality, but never linear as in coccineifrons, cryptorhynchus and similis.

Weight $53-61 \mathrm{~g}$.

\section{Cicinnurus regius similis Stres.}

Cicinnurus regius similis Stresemann (ex Neumann MS.), Journ. f. Orn. 1922, p. 405 (Torricelli Mts. to Astrolabebay).

Mayr found the "King Bird" apparently very common near Hollandia and Hol, from where he sent a fine series, obtained in August, and from the Cyclops Mountains and Ifaar, shot in the latter part of August.

Weight $50-52$, rarely $56 \mathrm{~g}$.

The iris of all Cicinnurus regius is brown, the bill in males yellow, feet light "violet blue." In females the iris is also brown, bill duller yellow, feet " blue." The testes of the red males were more or less enlarged, but also those of a male in female plumage were greatly enlarged. Males shot August 3rd and October 10 th and 15th are in full moult from the brown female plumage to the red one. A male shot $13 . x$. has a curious plumage which is, I think, the second year's garb ; it is mixed, but the brown parts are not greyish olivaceous brown, but more yellowish brown, while the elongated central rectrices are only half rolled up and their shafts are not quite bare; in the specimen from October 13th one of these feathers is like that of a perfectly adult male and the underside has the green pectoral bar and white abdomen, also the green-tipped pectoral tufts! I do not know how Ogilvie-Grant made out that the first plumage was worn two years. I think they must moult into the "mixed" garb in the second year.

The females and out-of-plumage males and young are perfectly alike, except that the males have a bit longer wings. All these birds are on the upperside more greyish olivaceous than females and juv. of $C$. r. claudii, while those of $C$. r. regius (Aru Islands) and C. r. coccineifrons (Jobi) are in colour like similis! In some young males in first plumage the middle rectrices are several millimetres longer than the rest, and show a slight enarrated web on the tip which is slightly curved.

The Berlin Museum received from Prof. Schultze some skins from the mouth of the Tami River, but these specimens cannot possibly be correctly labelled, therefore I fear they may have been received from natives because they agree absolutely with $C$. $r$. coccineifrons from Jobi, not even with Stresemann's cryptorhynchus from the north coast, though the latter is very near to coccineifrons.

\section{Diphyllodes magnificus magnificus (Penn.).}

Paradisea magnifica Pennant, Forster's Indische Zool., Faunula Indica, p. 40 (1781-Ex Daubenton's Oiseau de Paradis de la Nouvelle Guinée dit le Magnifique, pl. 631. Terra typica restricta: Arfak !).

Paradisea speccosa (error for speciosa), Boddaert, Tabl. Pl. Enlum. p. 38 (1783-Also ex Daubenton's pl. 631).

Both Ernst Mayr and Shaw Mayer sent skins from Arfak, the former a fine series from Siwi, and also from Wondiwoi, Wandammen, the latter two males from near Sorong, 200 feet alt., and Agamuri village, 1,000 m. alt. The iris is dark brown, bill bluish white, light bluish grey, lead-grey, whitish bluegrey, the feet bright blue, violet-blue. Weight of $85-111$, 우 71-88 g. The 
Manikion name according to Shaw Mayer "Pena," the Malayan name "Batarotang." A specimen from 17.v. in full moult.

The nomenclature and distribution of the various forms of Diphyllodes magnificus requires some explanation as it has hitherto not been sufficiently understood.

The oldest name is Pennant's Paradisea magnifica of 1781. This name, magnifica, has also been usually used, by Salvadori, Sharpe, Rothschild, Stresemann and most others, but Ogilvie-Grant, Ibis, 1915, Suppl. p. 22, preferred the name speciosa ("speccosa") because he did not look up Salvadori nor Rothschild, and quoted Pennant in Forster's Ind. Zool. 1795, but the first edition of that appeared in 1781. Moreover, Ogilvie-Grant applied the name speciosa (both names, magnifica and "speccosa," were based on the same plate, 631, of Daubenton) to the wrong bird. There is no doubt whatever that Daubenton figured the form with what Ogilvie-Grant called " clay-coloured " secondaries, though the clay-colour has a distinct yellow admixture and is glossy. Mayr's and Mayer's specimens from the Arfak region show without doubt that the Arfak form is the one with yellowish glossy clay-coloured secondaries. The colour of the secondaries (in many descriptions called "wings"!) varies somewhat, sometimes being darker, more brownish, sometimes paler (probably faded), but it is never orange. Sharpe, in his Monograph of the Birds of Paradise, figured specimens with somewhat darker secondaries, under the name of $D$. seleucides Lesson, but seleucides is obviously a synonym of magnifica. Ogilvie-Grant, Ibis, 1915 Suppl. p. 24, gave the name of "Diphyllodes rothschildi sp. nov." to specimens from a plumassier, supposed to have come from Salwatti, with duller "clay-coloured wings." This was entirely erroneous, as the birds with " claycoloured " secondaries are the ones inhabiting Arfak, and in fact most or the whole of the Berau (or Arfak) Peninsula, as Mayer collected a specimen near Sorong. Goodfellow (Ibis, 1915 Suppl. p. 25) must be quite right that there are no Paradise-Birds on the little island of Sorong, but that all skins purchased there come from Salwatti is doubtful, as it also occurs near by on the mainland.

[Along the foot-hills of the Snow Mountains occurs a form with the secondaries brighter, more glossy and more orange yellow than in magnificus, but much less bright than in chrysopterus, though somewhat variable. They are thus clearly intermediate between magnificus and chrysopterus and cannot be united with either of these, consequently they must have a new name, and I call it by the name that is suggested by these facts :

\section{Diphyllodes magnificus intermedius, subsp. nov.}

Type: $\hat{o}$ ad. Snow Mountains, 2,500 feet, 13.viii.1910. No. 4604, A. S. Meek coll.

We have now three males, two from Meek, one collected by Pratt Bros. from the Wanggar district, south of Geelvink Bay, 2,000 feet high, 20 miles from the sea, January 1921. Wings 114, 115, $116 \mathrm{~mm}$. The females have wings of $105,106 \mathrm{~mm}$., and agree in coloration with the Arfak birds, D. m. magnificus. There are half a dozen fully adult males from the Kapare, Waitakwa, Utakwa valleys, agreeing with ours, though one is a bit more bright, but not like $D . m$. chrysoptera! One is partially bright orange on the secondaries, but this is obviously not normal and apparently stained.] 
A form with orange secondaries inhabits Jobi and the north coast of Papua as far east as the Speik river district and possibly still farther eastwards (Astrolabe Bay ?). This form must be called chrysopterus. This name is beyond doubt.

Stresemann rejected it, because it is uncertain that the type came from Jobi, but the type is in the British Museum and has been well described and figured, so whether it came from Jobi or the north coast of New Guinea, there is no doubt about its meaning, and jobiensis Meyer 1885 is a synonym of it.

East New Guinea, i.e. what used to be called British New Guinea, now an Australian colony (stupidly called "Papua" in opposition to other parts of New Guinea, while Papua is the old name often applied to New Guinea as a whole, and by no means given to the British colony in particular), and the Kai or Huon Peninsula: Simbang, Bongu, Sattelberg, Finisterre Mountains are inhabited by a race with bright orange secondaries, shorter wings, generally more reddish back and rump and much more glossy orange crown. This form is hunsteini Meyer, septentrionalis being a synonym.

The females also differ slightly.

Those of D. magn. magnificus from the Arfak (Berau) Peninsula and Wandammen, also Kapaur (Onin Peninsula) have the upperside olivaceous, with a more or less distinct golden or rufescent tinge, and underside is more rufescent, wings ㅇ 106-110, once 112, males in female plumage wings 113-115.

Females of $D$. magnificus chrysopterus are above more olivaceous, the edges to the wings less yellowish, more greenish, and the underside lacks the slight rufescent tinge of magnificus. Wings of $f$ 110-115, males in female plumage 117-119 $\mathrm{mm}$.

Females of $D$. magnificus hunsteini have the upperside more reddish brown, especially the crown more rufous. Wings o 104-110, once 112, males in female plumage 110-116 $\mathrm{mm}$.

\section{Diphyllodes magnificus chrysopterus Elliot.}

Diphyllodes speciosus var. chrysopterus Elliot (ex Gould MS.), Mon. Paradis. text to piate 13 (1873Locality unknown).

Diphyllodes jobiensis Meyer, Zeitschr. ges. Orn. ii, p. 388 (1885-Jobi).

A fine series of both sexes from Hollandia (August) and the Cyclops Mountains (end of August).

The iris was found to be dark brown, but in a white-spotted variety $(\hat{\sigma})$ it was whitish grey! This specimen has the whole upperside intermixed with white feathers and a few white feathers on the throat and chest.

Weight ơ 92-111, 우 83-104 g. follows :

The forms of Diphyllodes magnificus to be recognized are therefore as

1. Diphyllodes magnificus magnificus (Penn.).

Paradisea magnifica Pennant, Fors er's Ind. Zool., Faun. Ind. p. 40 (1781-Ex Daubenton 631).

Paradisea speccosa (err. for speciosa) Boddaert (1783 - Based also on Daubenton 631).

Diphyllodes seleucides Lesson, Hist. Nat. Ois. Paradis (1835-New name for magnificus).

Diphyllodes rothschildi Ogilvie-Grant, Ibis, 1915, Suppl. p. 24 (Salawatti or Salwatti Island, from a specimen in the Gould coll.)

Arfak (Berau) and Onin Peninsula, also Salwatti.

2. Diphyllodes magnificus intermedius Hart.

See above, p. 36 . 
Foot of Snow Mountain Range, Kapare, Iwaka, Utakwa Rivers, up to 2,500 and 2,900 feet.

3. Diphyllodes magnificus chrysopterus Ell.

Diphyllodes speciosus var. chrysopterus Elliot, ex Gould MS., Mon. Paradis. text pl. 13 (1S73-

Locality unknown).

Diphyllodes jobiensis Meyer, Zeitschr. ges. Orn. ii, p. 388 (1885-Jobi).

Jobi and north coast east of Geelvink Bay at least as far east as the Sepik River.

\section{Diphyllodes magnificus hunsteini Mey.}

Diphyllodes Hunsteini A. B. Meyer, Zeitschr. ges. Orn. ii, p. 389 (1885-"Hufeisengebirge" in Owen Stanley Range).

Diphyllodes chrysoptera septentrionalis A. B. Meyer, Journ. f. Orn. 1892, p. 261.

Diphyllodes xanthoptera Salvadori, Ann. Mus. Genova, xxxvi, p. 111 (1896-Bubui River, north of Huon Gulf).

Eastern Papua, former British (now Australian) New Guinea and former German colony (now "Mandated Territory").

\section{Paradisaea minor minor Shaw.}

Paradisea minor Shaw, Gen. Zool. vii, 2, p. 486 (1809-No locality. I substitute Arfak, from where these birds used to come).

Adult males, females, and junior birds from Arfak (Siwi and Momi), Wondiwoi in the Wandammen Peninsula, and again near Hollandia and Mount Cyclops. From April to July males were in fullest plumage, but one April male is moulting. Shaw Mayer sent a male from the "mainland" opposite Sorong Island in full plumage, shot in October.

The iris is yellow, with a faint tinge of green, feet grey to bluish-slate colour, bill bluish grey, whitish grey, " almost lavender."

Weight 225-285 g.

The males in female plumage are larger than the females, and the underside, from the throat onwards, is snow white, with a more or less distinct yellow tinge on the sides. The females sent by Mayr have a brownish red zone beyond the dark brown throat, and this brownish red colour spreads along the sides. This, however, is apparently not a peculiarity of the females, but may be a sign of juvenility, as Doherty sent also males of that coloration.

The ornamental plumes of the males are in fresh plumage very bright, quite orange, especially in one from Momi, but in the collection they seem to get lighter, less orange.

\section{Manucodia chalybatus chalybatus (Penn.).}

Paradisea chaly'sata Pennant, Forster's Zool. Ind., Faunula Indica, p. 40 (1781-Ex Daubenton's pl. 634, New Guinea).

Both sexes were collected near Siwi, Wondiwoi and Wasior (in the coastal forest) in April, May and July. The iris of adult males was red or yellowish red. Wings ô ad. 180-187, ㅇ $176 \mathrm{~mm}$.

Weight ô $225-250$, 우 $210 \mathrm{~g}$. 


\section{Manucodia chalybatus orientalis Salvad.}

Manucodia orientalis Salvadori, Ann. Mus. Civ. Genova (2), xvi, p. 103 (1896-Owen Stanley Mts.). 2 ô, 1 \& Hollandia and Ifaar on Lake Sentani. Wings ô 174, 180 !, o $160 \mathrm{~mm}$. Weight "우" 210 , ơ $240 \mathrm{~g}$.

\section{Manucodia ater ater (Less.).}

Phonygama ater Lesson, Voy. Coquille, Zool. i, part 2, p. 638 (1828-Dorey, Arfak).

A good series from Manokwari (Arfak), Wasior, Ifaar and Holiandia. Iris red.

Weight oิ 205,210 , 우 200, $225 \mathrm{~g}$.

\section{Phonygammus keraudrenii keraudrenii (Less. \& Garn.).}

Barita keraudrenii Lesson et Garnot, Férussac's Bull. Sc. Nat. et de Géologie, viii, p. 110 (1826Descr. from specimens collected by Lesson at Dorey, Arfak).

Fourteen skins from Siwi, Manokwari, the hills near Siwi and Momi.

Weights ô 140-175, ㅇ 130-140 g.

These specimens show great variation in the colour, especially in that of the back which varies from a glossy steel-green to glossy purplish blue. The females are like the males, but are smaller and the tufts above and behind the eyes are as a rule shorter. Moulting specimens show that the juvenile plumage is a sort of raven-black, burnished or graphite black. The iris, at least of adult birds, is red, bill and feet black. This series is very instructive, and it confirms my idea that there is only one form in S.E. New Guinea.

Lord Rothschild was the first to state in print that Ph. jamesi Sharpe (Cat. B. Brit. Mus. iii, p. 181, 1877, Aleya, S.E. New Guinea) was the juvenile of $\mathrm{Ph}$. purpureoviolacea Meyer 1885, described from the Astrolabe Mountains.

In 1915 Ogilvie-Grant (Ibis Suppl. pp. 5 and 6) declared that in S.E. New Guinea lived a form of the plains, which was identical with keraudrenii, while in the mountains lived purpureoviolacea, jamesi Sharpe being the young of keraudrenii and not of purpureoviolacea; he says that Lord Rothschild now agreed with him; apparently he wavered once in conversation, but I am of opinion that he was quite right in admitting jamesi as the young purpureoviolacea, and not as the young of keraudrenii. We know from the series in Tring and elsewhere that both keraudrenii and hunsteini (the form of the D'Entrecasteaux Islands) have blackish young, and our specimens in moult prove to me that the same is the case with jamesi (= purpureoviolacea). The specimens from S.E. New Guinea which Ogilvie-Grant declares to be keraudrenii are nearly all in moult from a juvenile plumage; one specimen, said to be from the Brown River, collected by Emil Weiske, but without indication of date and sex (though from size surely a female) is indeed very similar to a keraudrenii, but the two forms are of course closely allied, and some stages of plumage vary much and young of the two forms are not always distinguishable; the rectrices of young are more pointed than in the adult birds. Nor is there in my opinion enough material to prove that the more brilliant birds (" purpureoviolacea") are all from higher elevations; in fact we have a specimen which Ogilvie-Grant called keraudrenii shot by A. S. Meek's men at about 6,000 feet or more. Grant somewhat doubted the correctness of the elevation, but there can be no doubt about that whatever, so Grant ruled it out as an exceptional occurrence. 
We have therefore the following forms of Phonygammus, which are all subspecies :

\section{Phonygammus keraudrenii keraudrenii (Less. \& Garnot).}

Berau and Onin Peninsulas, southern slopes of Snow Mountains, east apparently to the Fly River, and Aru Islands.

Phonygammus keraudrenii neumanni Rchw. 1918.

Only known from the Lordberg, about 1,058 m., on the Upper Sepik River.

Phonygammus keraudrenii jamesi Sharpe 1877.

Synonym $P h$. purpureoviolacea Meyer 1885.

South-East New Guinea, chiefly on the mountains.

Phonygammus keraudrenii hunsteini Sharpe 1882.

Fergusson and Normanby Islands.

Synonym Manucodia thomsoni Tristram, Ibis, 1889.

Phonygammus keraudrenii gouldii Gray 1859.

Synonym Phonygammus yorki Mathews 1924.

Cape York Peninsula (North Queensland).

\section{Oriolus szalayi (Mad.).}

(Oriolus striatus Quoy et Gaimard 1830 is unfortunately preoccupied by Oriolus striatus Hermann 1783 !)

Mimeta szalayi Madarász, Termeszetrajzi Füsetek, xxiv, p. 80 (1901-Madang (Finschhafen), North New Guinea).

ô Manokwari, 7.iv. 1928.

구우 near Siwi, 26.iv, 5.v.1928.

Iris blood-red. Bill red. Feet grey or black.

The female has the face and throat blacker; we have a number of birds

like it, but this character does not seem peculiar to the female sex, according to the material available.

\section{Mino dumontii dumontii Lesson.}

Mino dumontii Lesson (1826-Dorey, now called Manokwari).

Both sexes from the terra typica, Manokwari, from Wasior, Hollandia, Momi and Ifaar on Sentani Lakes. Males have longer wings than females.

The Manokwari specimens of April 10th and 11th have numerous little white plumes on the back and sides of the neck, and some on the black portions of the abdomen and back. These were correctly described by Sharpe as " hairlike white plumelets," and even more in detail by Lesson, Voyage Coquille, i, p. 652, as long ago as 1826 . They look at first glance as if they were appendices on the tip of the feathers, but they are independent feathers rising from the skins between the feathers, quite narrow, shafts only, at base, but at the tip with a droplike white spatula. It seems that they are only greatly in evidence in freshly moulted birds, while they are worn off and largely fall out later onperhaps they are comparable to the small white ornamental plumes of the cormorants, which disappear when the breeding time begins! 
28. Aplonis (Calornis) metallicus metallicus (Temm.).

Manokwari, Hollandia.

\section{Aplonis cantoroides cantoroides (Gray).}

Ifaar (Sentani Lakes), 15., 18., 19.ix. 1928.

\section{Dicrurus bracteatus carbonarius Bp. 1850.}

This common bird was met with and collected at Wasior (coast) 23., 24.vii.1928, Momi 2.vii.1928, Hollandia August and October, Cyclops Mountains 31.viii.1928, and Ifaar on Lake Sentani, end September 1928. The iris of adults is red, of the young greyish brown. A female from Ifaar in moult is mainly covered with a soft downy smoky black plumage, a few metallic glossy feathers beginning to grow on the underside, many on the upperside, wings and tail. As the body is about full grown and the dull black downy feathers are much too long for a first nestling's plumes it seems as if that downy sort of fluff dress is a second "mesoptile" plumage.

Adult females are like males, but considerably smaller.

Weight $73 \cdot 5-86 \mathrm{~g}$.

\section{Chaetorhynchus papuensis Meyer 1874.}

Terra typica, Arfak.

A big series from Siwi, April and Wondiwoi Mountains in the Wandammen Peninsula, July. Iris very dark brown. At the base of the inner secondaries is a hidden patch of small entirely or partially snow-white feathers. Salvadori described them as a scapular patch, Meyer and Sharpe do not mention this peculiarity. Skins from Siwi partially in moult, some showing remains of a loose fluffy juvenile plumage. Females smaller than males.

Weight $37-49 \mathrm{~g}$.

32. Artamus maximus A. B. Meyer.

Siwi and Ditschi. Iris deep brown. Bill grey-blue.

Adults weigh $53,55,58,63 \cdot 5,71 \mathrm{~g}$.

\section{Artamus leucorhynchus leucopygialis Gould.}

Seven ad. from Ifaar on Sentani lakes, middle September, 1 Kaju Pulu (near Hollandia), 15.x.1928.

Wings $125-137 \mathrm{~mm}$. Adults weigh $40-44 \mathrm{~g}$.

Stresemann, Nov. Zool. 1913, pp. 289, 292, separates A. leuc. leucopygialis, wing 121-135 mm., average about $129 \mathrm{~mm}$., from Australia, S.E. New Guinea, and Fergusson Islands (possibly only winter visitors in New Guinea), and A. leuc. papuensis Bp., wing 128-139 mm., and bill larger, from the Moluccas, Western Papuan Islands and New Guinea, with exception of S.E. New Guinea.

As will be seen, the wing-measurements of the Ifaar birds are hardly decisive. The bills are, it is true, sometimes much smaller in the Australian form, but very often, if not mostly, as big as in "papuensis." Although I myself once separated the Cape York form as parvirostris I did not afterwards recognize it as different. I believe it will be better to await more material before separating 
leucopygialis and papuensis, though it seems that some of the former do have smaller bills, and often shorter wings.

\section{Munia vana spec. nov.}

o Upperside earth-brown, lighter on the forehead, darker on the back. Upper tail-coverts with dull straw-yellow tips, middle rectrices with strawyellow edges, apparently slightly elongated and tapering. Quills deep brown, inner edges fawn colour. Chin and sides of head under eyes brownish white, a brown form side to side over the jugulum, followed by a narrow dull white band, breast and abdomen, thighs and under tail-coverts light chestnut-ochraceous. "Iris dark, bill leaden grey, feet dark grey. "Wing 51.5 mm., tail worn.

Kofo, Anggi gidji Lake, 11.vi.1928. Typus!

Beside the type there are three others, all three sexed " of" which were bad skins, but are now made up quite nicely, all from the same place and date. Two are evidently adult males in moult, the third moulting from the juvenile plumage to that of the adult, and there is one young. They agree in coloration with the type. The wings measure 50-51 $\mathrm{mm}$.

Weight $10-12 \mathrm{~g}$.

\section{Munia spectabilis mayri subsp. nov.}

Differs from Munia spectabilis spectabilis (Scl.) of New Britain by having the back lighter, without any trace of the blackish colour on the interscapulium, and the bills are smaller. "Iris brown. Bill whitish-grey, feet dark grey" (Mayr). The upper tail-coverts are also much more yellow, not so brownish as in $M . s$. spectabilis. Wings of $46,47,48,49$, ㅇ $46,47,48 \mathrm{~mm}$.

Weight $8-9 \cdot 5 \mathrm{~g}$.

Type : ô ad. Ifaar, 27.ix.1928. No. 2639 Mayr coll.

A series Ifaar, Sentani Lake, September and October. Sexual organs large in both sexes, evidently laying.

Named after its discoverer, Dr. Ernst Mayr.

36. Munia grandis destructa subsp. nov.

Very close to $M$. grandis grandis, but back more brownish, upper tail-coverts and edges to rectrices yellower. Wing ô 58 , q $50 \mathrm{~mm}$.

Type: $\nmid$ ad. Ifaar, 22.ix.1928. No. 2508 Ernst Mayr coll.

These two specimens were collected inland and were not brought in before night, when they were already in bad condition. Only two specimens, $\hat{\sigma}$ and $q$, were shot, and the male lost its tail.

\section{Munia tristissima Wall. 1865.}

Adult and young were collected at Siwi, Arfak, where the type eame from, Ditschi and Ifaar on Lake Sentani. We had it formerly also from the Hydrographer Range.

Weight $8 \cdot 5-12$ g. ${ }^{1}$

1 Munia tristissima was described from Arfak. Later on Reichenow described Munia calaminoros (Orn. Monatsber. xxiv, p. 169, 1916, Augustahafen), but Stresemann says that he compared his type with Arfak specimens, and does not separate it. I believe that the brown and spotted specimens are females, but our Arfak material is poor. Possibly an eastern subspecies will be separable, but our present material does not enable me to understand these forms. 
38. Munia castaneothorax sharpii (Mad.).

Donacicola sharpii Madarász, Bull. B.O. Club, iii, p. xlvii (1894-Bongu).

ơ우 ad. Ifaar, Lake Sentani, 19.ix. 1928.

The males have the crown of the head lighter than the females. Probably the birds from Vulcan Island should be separated, because they have lighter backs, but more material from the mainland of Papua should be compared.

Weights ô 10 , ㅇ $10 \cdot 5 \mathrm{~g}$.

\section{Erythrura trichroa sigillifera De Vis.}

Lo'ospingus sigillifer De Vis, Ibis 1897, p. 389. (No locality. but apparently Mt. Seratehley.) Erythrura trichroa goodfellowi Ogilvie-Grant, Bull. B.O. Club, xxix, p. 29 (1911-Moroka Mts., S.E. New Guinea).

ô Mountains near Ditschi 31.v., ô ad. and juv. Kofo (Anggi gidji), 12.vi. 1928.

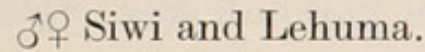

These birds belong to the small form, named goodfellowi.

Weight $13-15 \mathrm{~g}$. Wings $61-63 \mathrm{~mm}$.

A synonym is evidently Erythrura trichroa ma:gillivrayi Mathews, Austral Avian Record, ii, p. 103, 1914, from the Claudie River, North Queensland. Mathews says the blue on the head goes farther over the crown, but this is not constant.

\section{Erythrura papuana Hart.}

Erythrura trichroa papuana Hartert, Nov. Zool. vii, p. 7 (1900-Arfak Mts.)

ô ad. Siwi, Arfak Mountains, 27.iv. 1928.

† ad. Siwi, 10.v.1928.

"Iris dark brown, bill black, feet pale flesh colour or pale reddish brown." Weight 19 and $21 \mathrm{~g}$.

These two birds agree with the type, having a very large bill, wings of 69 and $68.5 \mathrm{~mm}$., the blue on the forehead extending almost as far back on the crown as in the type. We have similar specimens from the Aroa River and Kotoi in S.E. Papua.

This form occurs in the same countries with the form described as goodfellowi by Grant, it ean therefore not be a subspecies of trichroa, if goodfellowi it is. We have thus a similar case as in the genus Geospiza on the Galapagos Islands, a large and a small form occurring together.

\section{Myzomela nigrita nigrita (?).}

Myzomela nigrita Gray, Proc. Zool. Soc. 1858, pp. 173, 190 (Aru Islands).

Mayr sent two adult males from Siwi, Arfak Mountains, May 1928, weighing 9 and $10.5 \mathrm{~g}$.

These two males (females were not sent) agree with males from the Aru Islands. Their wings measure $59-60 \mathrm{~mm}$. Specimens of $M$. nigrita meyeri from the Sepik River Mountains have longer wings, up to $64 \mathrm{~mm}$., but some are, teste Stresemann, smaller, with wings only $58.5 \mathrm{~mm}$. The distribution given by Stresemann is peculiar; most of our S.E. Papuan birds agree more or less with the Arfak birds, and so do some from the Snow Mountains, while others from there have still shorter wings. 
42. Myzomela cruentata cruentata A. B. Meyer.

Myzomela cruentata A. B. Meyer, 1874, Arfak.

Dr. Ernst Mayr sent a series from the Arfak Mountains, from Siwi and Ditschi, April, May and June.

Also two males from the Cyclops Mountains, 24.viii.1928.

ô ad. $7 \cdot 5-8 \mathrm{~g}$.

\section{Myzomela erythrocephala adolphinae Salvad.}

Myzomela adolphinae Salvadori, 1875, Arfak.

Two o near Siwi, Arfak.

Weight 7 and $8 \mathrm{~g}$.

The females of $M$. e. adolphinae differ from those of $M$. cruentata cruentata by their smaller bill, lighter upper- and underside and brown tail and rump without red edges! " Iris dark brown, bill black, feet brownish grey or reddish grey."

\section{Myzomela rosenbergii Schleg.}

Myzomela rosenbergii Schlegel, 1871, Arfak Peninsula.

Mayr found this species on the mountains above Ditschi, between 1,200 and 1,500 m., at the Gunong Mundi near Ninei, 1,800 m., and on the Cyclops Mountains. On the latter they were apparently breeding. Iris dark brown.

Weight 9-11.5 g.

\section{Myzomela eques eques (Less.).}

Cinnyris eques Lesson, Voy. Coqu., Zool. i, p. 678, pl. 30 (1828-Waigiu and Arfak Peninsula).

1 ô ad. Siwi, 11.v.1928.

ㅇ juv. Hollandia, 13.x.1928.

The last specimen agrees with a pair from the Mamberano River described by Rothschild and Hartert, Nov. Zool. 1903, p. 223. Stresemann has described the juvenile plumages, and I am now sure that our specimens from the Mamberano and Hollandia about which we were doubtful are juvenile eques.

\section{Toxorhamphus iliolophus iliolophus (Salvad.).}

Melilestes iliolophus Salvadori, 1875 (Miosnom and Jobi).

Siwi, mountains near Ditschi 1300 m., Ditschi, Hollandia, and Cyclops Mountains. ${ }^{1}$

All these birds, like those from Jobi and Arfak, do not exhibit the pale yellow tufts of flank feathers which are conspicuous in a series from S.E. New Guinea, but some are intermediate. "Iris brown, bill black, feet grey."

The females are, as is well known, much smaller than the males.

For the genus, see Nov. Zool. xxi, p. 394, 1914.

Weights ơ 11-13.5, 우 9-10 g.

1 The specimens from the Cyclops Mountains are probably like the typical iliolophus from Miosnom and Jobi, of which, however, no good skins are available. Skins from the Arfak Peninsula seem to be less greenish, especially on the head, while S.E. Papuan birds are paler! There are therefore probably three subspecies (except fergussonis), but finer skins from Arfak are desirable! 
47. Toxorhamphus novaeguineae novaeguineae (Less.).

Cinnyris Novae-guineae Lesson, Voy. Coquille, Zool. 1828 (Arfak, Dorey).

Siwi, mountains above Siwi, Hollandia and Cyclops Mountains.

Weights ô 13-14, q 10 and $11 \cdot 5 \mathrm{~g}$.

48. Melilestes megarhynchus stresemanni subsp. nov.

Differs from $M$. megarhynchus megarhynchus from the Arfak region, Kapaur, lower Snow Mountains, Aru Islands and S.E. Papua by the colour of the underside, which is less yellowish-greenish, more greyish-brownish, and the darker, browner upperside. In colour like $M . m$. vagans of Waigiu, but bill slenderer!

The bill of $M . m$. vagans is much thicker than that of its allies.

Type of M. m. stresemanni ô ad. Hollandia, 13.x.1928. No. 2835 Ernst Mayr coll.

"Iris red. Bill black. Feet grey."

Mayr sent 2 ๙ Hollandia, 1 우 Cyclops Mountains, 23.viii.1928. Wings ô 101,103 , 우 $105 \mathrm{~mm}$.

To this subspecies belong also our birds from Takar, W. A. Doherty coll. 1896. Their wings measure of 102-104, of $95 \mathrm{~mm}$.

Weights ơ 46,47 , 우 $42,45 \mathrm{~g}$.

\section{Melilestes megarhynchus megarhynchus (Gray).}

Ptilotis megarhynchus Gray, Proc. Zool. Soc. 1858, p. 174 (Aru Islands, type a young bird).

1 of ad., 1 ㅇ juv. Siwi, Arfak, 2.v.1928. ㅇ ad. $40 \mathrm{~g}$. Iris of the adult "rötlich (gelb)," of the young brown. The young are underneath streaked with very pale yellow, and there is a pale sulphur yellow ring round the eye.

\section{Glycichaera fallax Salvad.}

ô ad. Siwi, Arfak, 16.v.1928. "Iris hellgelb. Schnabel schwärzlich. Füsse blaugrau."

Weight $12 \cdot 5 \mathrm{~g}$.

\section{Oedistoma pygmaeum pygmaeum Salvad.}

ㅇ Siwi, 15.v. 1928.

q Cyclops Mountains, 24.viii. 1928.

+ Hollandia, 11.x.1928.

Weight $5-5 \cdot 5 \mathrm{~g}$.

52. Melipotes fumigatus goliathi R. \&. H.

Melipotes gymnops goliathi Rothschild \& Hartert, Nov. Zool. xx, p. 515 (1913-Mt. Goliath).

Eleven specimens of both sexes from the Cyclops Mountains, first half of September. The sexual organs were rather highly developed. "Iris brown, bill black, feet grey." The large patch of bare skin around the eyes is "gamboge " according to Boden Kloss.

The distribution is rather interesting : Mount Goliath, Utakwa River, Mount Kunupi on the Weylandt Mountains, Schraderberg on the Upper Sepik River and Cyclops Mountains : " ơ" wing 122, 117, 112, 115.5, 120, 119, 124, $114 \mathrm{~mm}$. "ㅇ" wing 110,111.5, $111 \mathrm{~mm}$. 
Weight $\hat{o} 52-64$, 우 $50-58 \mathrm{~g}$ !

I conclude from these measurements that Stresemann's supposed larger form anthophilus from the Hunsteinspitze are not separable from $M . f$. goliathi, otherwise we would have both forms from the Cyclops Mountains, as topotypical goliathi measure ô 114-117, and two from Mount Kunupi 120, females $109-111 \mathrm{~mm}$.

\section{Melipotes gymnops Sel.}

Melipotes gymnops Sclater, Proc. Zool. Soc. London, p. 695, pl. 56 (Hatam in the Arfak Mts.).

Mayr sent a series from the mountains near Siwi and Ditschi, from Lehuma and Wondiwoi in Wandammen. "Iris brown." "Nackte Haut dunkel dottergelb." ô wings $115-120$, ㅇ $108-112$, once $115 \mathrm{~mm}$.

Weight oิ $58-61 \cdot 5$, 우 $48-55 \mathrm{~g}$.

\section{Melidectes torquatus torquatus Scl.}

Melidectes torquatus Sclater, Proc. Zool. Soc. London, 1873, p. 694, pl. 55 (Hatam, Arfak).

This subspecies, by no means common in collections, seems only known from Arfak, where Mayr collected seven specimens in the mountains near Siwi and Ditschi. Only two were males. The sexes are alike in coloration, but the males are considerably larger. ô wing 112,115 , 우 $102-105 \mathrm{~mm}$.

Weight ô 48 , ㅇ $39-45 \mathrm{~g}$ !

"Iris dark. Bill and feet blue-grey. Naked space around eyes bright lemon-yellow ; bare skin at base of bill brick-red; little lappet on upper edge of rictus whitish pink."

\section{Melidectes (Melirrhophetes) leucostephes Meyer.}

Mountains of Siwi, Ditschi and Lehuma.

This form seems to be only known from the Berau Peninsula, now called "Vogelkop."

Naked skin around eyes whitish sky-blue, wattles on sides of neck bright brick-red.

Its iris is very dark, bill whitish or bluish grey, feet blue-grey (Mayr). The characteristic wattles on the sides of the foreneck are present in both sexes, but absent in young. The colour of these wattles is dark brick-red (E. Mayr).

Weight ôे $78-93$, ㅇ $65-78 \mathrm{~g}$ !

\section{Melidectes (Melirrhophetes) ochromelas ochromelas Meyer.}

Melirrhophetes ochromelas A. B. Meyer, Sitzungsber. Akad. Wissensch. Wien, lxx, p. 111 (1874Arfak Peninsula).

Two mountains near Ditschi, June.

Three Lehuma, June.

One Wondiwoi, Wandammen Peninsula, 10.vii.1928.

"Iris dark grey and dark brown, skin around eye greenish white, feet whitish, in the Wondiwoi specimen (o) 'hellblaugrau.',

Weight of $61 \cdot 5-65$, ㅇ 54-62.5 g !

As usual female smaller, otherwise like male. $M$. ochromelas batesi inhabits S.E. New Guinea. 
57. Meliphaga notata sharpei (R. \& H.).

Ptilotis aruensis sharpei Rothschild \& Hartert, Nov. Zool. x, p. 442 (1903-Dorey in Arfak).

A very typical male, with long yellow ear-tufts and with blackish middle portions of the elongated rump feathers was obtained at Ifaar on Lake Sentani, near Hollandia, 15.ix.1928. Testes much enlarged! "Iris greyish brown. Bill black. Feet grey." Wing $89 \mathrm{~mm}$.

Weight $27 \mathrm{~g}$.

(Stresemann, Journ. f. Orn. 1925, in his excellent article on the forms and allies of Mel. analoga deseribes $M$. analoga vicina as a subspecies of notata, but I think that it is rather a form of $M$. analoga !)

\section{Meliphaga analoga analoga (Reichenb.).}

(The type of Reichenbach's analoga was apparently from Triton Bay.)

Collected at Manokvari (Dorey), Siwi, Ditschi, Hollandia, Ifaar and Cyclops Mountains. Quite young birds resemble the old ones very much in coloration, but are paler.

Weight of ad. 18.5, 22, ㅇ $18-20 \mathrm{~g}$.

The specimens from Ifaar and Cyclops Mountains have mostly darker yellow ear-coverts, one female from Manokwari has white ear-coverts (aberr. albonotata). Possibly more than one subspecies may be separable on the mainland of New Guinea, but I doubt it. Specimens from Arfak are usually duller ! The genus Meliphaga (formerly Ptilotis) has been reviewed by me in Nov. Zool. 1913, p. 519, and by Stresemann, Journ. f. Orn. 1925, p. 255. Grant's review in Ibis, 1915, Supplement, p. 63, is greatly confused.

\section{Meliphaga montana montana (Salvad.).}

Ptilotis montana Salvadori, Ann. Mus. Civ. Genova, xvi, p. 77 (1880-Arfak Mts.); id. Orn. Pap. ii, p. 333 .

Mayr sent three skins of this somewhat uncommon form from the Arfak region :

q Manokwari, 9.iv.1928. Wing $79 \mathrm{~mm}$.

2 of Siwi, 29.iv. and 1.v.1928. Wing $88,89 \mathrm{~mm}$.

Weight $32 \mathrm{~g}$.

The outer edges to the quills are olivaceous-greenish !

60. Meliphaga montana germanorum subsp. nov.

Three specimens from the Sattelberg (Wahnes coll.), from the Hunsteinspitze on the Upper Sepik River (Bürgers coll.) and the Cyclops Mountains (Ernst Mayr coll.) are very much darker, not greenish but a deep dark olive-brown on the upperside, which is especially striking on the quills. The undersurface is not uniform, but even more distinctly scaly than in topotypical montana, the feathers being greyish in the middle, and slightly yellowish on the edges. "Iris graubräunlich, Schnabel schwarz, Füsse blaugrau." Ernst Mayr collected specimens on the Sattelberg and in another locality in the "Mandated Territory " of Papua. Wings of 89-91, ㅇ $85 \mathrm{~mm}$.

Type: ô ad. Cyclops Mountains, 30.viii. 1928. No. 2097, Ernst Mayr coll. Weight $32 \mathrm{~g}$. 
Very near to $M$. montana germanorum (all specimens known to me were sent by German collectors) is the form from the Aicora River in S.E. New Guinea. They do not belong to $M$. montana montana, being much less greenish, especially on the wings. The Aicora River specimens are either $M$. montana germanorum or a new unnamed subspecies with slenderer bills.

M. montana mimikae, in the original description erroneously compared with $M$. orientalis, is not more greenish than $M . m$. montana and in fact not separable from the latter, except by having a generally smaller bill. More material must show if that is constant enough to warrant its separation as a subspecies.

\section{Stigmatops alboauricularis Rams.}

Stigmatops alboauricularis Ramsay, Proc. Linn. Soc. N.S. Wales, iii, pp. 75, 285 (1878 - Small islet near S.E. point of New Guinea).

3 ô Ifaar, 24.ix., 1.x., 2.x.1928. " Iris dark, bill black, feet grey."

Weights $13 \cdot 5,14,17 \mathrm{~g}$.

The distribution of this distinct and peculiar species is remarkable. Except the types there seem to be only known specimens collected by Tappenbeck on the Lower Ramu River.

\section{Xanthotis flaviventer flaviventer (Less.).}

Myzantha flaviventer Lesson, Manuel d'Orn. ii, p. 67 (1828-Dorey in Arfak Peninsula).

A number of specimens of both sexes from Siwi, April and May. Males much larger, wing of two males 108, 110, females 96-104 mm. Also one female from Wasior.

Weight 0 47 and 50 , 우 $40-44 \cdot 5 \mathrm{~g}$.

\section{Xanthotis flaviventer meyeri (Salvad.).}

Ptilotis meyeri Salvadori, Ann. Mus. Civ. Genova, vii, p. 947 (1875-Jobi).

Hollandia, Ifaar near Lake Sentani, evidently common. " Iris dark brown, bill black, feet grey." Males as usual much larger than females. The ear-tuft is orange yellow.

Weight ô $40-53$, ㅇ $42-47 \mathrm{~g}$.

\section{Xanthotis polygramma poikilosternos Mey.}

Xanthotis poikilosternos A. B. Meyer, Sitzungsber. k. Akad. Wiss. Wien, lxx, p. 112 (1874-Andai, at foot of Arfak Mts.).

우 ad. Hollandia, 11.x.1928, ô juv. Siwi, 9.v.1928. As mentioned already by Stresemann, the young bird lacks the white spots on the nape and has pale rufous or rusty edges to the upper wing-coverts-also the yellow ear patches are paler and sometimes washed with grey. Of the Siwi bird Mayr describes the iris as "dark," bill black, skin above and below the eye yellow, behind the eye pink.

Weight ô $20 \mathrm{~g}$.

It is curious that it has not hitherto been mentioned, that the Waigiu specimens have not yellow, but glossy ashy grey ear-coverts, a black line in front as in $X . p$. poikilosternos. The Waigiu bird has also longer wings, $2-3 \mathrm{~mm}$. $X$. polygramma (Gray) was originally described from Waigiu only, and it is 
therefore wrong in the Cat. B. Brit. Mus. ix, p. 233, to say that the Mysol specimens were the types! In fact the Mysol specimens differ again from poikilosternus. There are 5 in Tring and 4 in London and none of them has the crown black with short olive longitudinal stripes, but olive with some dull dusky spots and stripes. It is true we have only two adult ones, and those in London are juvenile, but the old birds also have the heads greenish, not blackish. Iris according to Kühn, chocolate or dark coffee-brown. Size as in $X$. $p$. poikilosternos.

Type: "q" Misol (Mysol), 21.i.1900. Heinr. Kühn coll.

I propose for the Misol subspecies the name

Xanthotis polygramma kuehni, subsp. nov.

(The three races were separated for years in the Tring Museum drawers.)

\section{Ptiloprora erythropleura (Salvad.).}

Ptilotis erythropleura Salvadori, 1875, Arfak Mts.

Eight skins from the mountains above Ditschi, $1500 \mathrm{~m}$., end of May, one from Lehuma, 29.v.1928. " Iris red-brown to red, bill black, feet blue-grey." Wing ô 83,90 , 우 $77-80 \mathrm{~mm}$.

Weight $\widehat{\circ} 21,21,23$, ㅇ 18.5-20.5 g.

As Pt. erythropleura and a subspecies of $P$. guisei occur together on the southern Snow Mountains, the latter and its allies cannot be subspecies of erythropleura. One of the important differences is the colour of the iris which is green or greenish in all known subspecies of Pt. guisei, but red or reddish brown in Pt. erythropleura. The latter is a new species for the Tring collection, which we had only known from descriptions and more recently from the coloured plate in Grant's Ibis Supplement, 1915.

66. Ptiloprora guisei praedicta subsp. nov.

4 ô, 1 ㅇ from Wondiwoi (Wandammen) are very closely allied to Pt. guisei lorentzi from the Snow Mountains, but the rump is less rufous-brownish. This form was already marked on the labels as "subsp. nov." by the collector, it is, however, surprising that it is so close to the Snow Mountains form.

Type : ô ad. Wondiwoi, 8. vii.1928. No. 1394 Mayr coll.

"Iris yellowish green, light greyish green. Bill black. Feet light blue-grey." Weight ô $30 \cdot 5-32$, ㅇ $26 \mathrm{~g}$.

Wings ô 101, 102, 104, ㅇ $90 \mathrm{~mm}$.

67. Ptiloprora guisei mayri subsp. nov.

Differs from $P t$. guisei guisei by larger size, the pure grey edges to the feathers on the head, which are olivaceous-grey in $P . g$. guisei, and somewhat narrower and less bright rufous edges to the feathers of the back. Wing 0 98-104, mostly 99-101, only once 194, ㅇ 90-94, mostly 90-92 mm. "Iris greyish green."

Weight ô $28 \cdot 5-35$, 우 27-29 $\mathrm{g}$. feathers.

The young have on the underside greenish sulphur-yellow edges to the

Type: $\widehat{o}$ ad. Cyclops Mountains, 31.viii.1928. No. 2125. Mayr coll, 
On 6.ix.1928 a female was shot with an egg ready for laying; others from the same time had the ovaries only a little developed.

This form was common on the Cyclops Mountains, west of Hollandia, where a fine series was collected.

\section{Ptiloprora cinerea cinerea (Scl.).}

Ptilotis cinerea Sclater, Proc. Zool. Soc. London, 1873, p. 693 (Hatam, Arfak Mts.).

A series of ten from Siwi and the mountains above Siwi, Arfak Mountains. The iris of this species is brown. The males and females are similar in colour, but the latter are smaller.

This is another form only known from the Arfak Mountains; it is represented in S.E. New Guinea by Pt. cinerea marmorata, which has also been collected on the southern slopes of the Snow Mountains.

In one female fruits were found in the stomach.

Weight ô $45,48,50$, ㅇ $40 \cdot 5-44 \mathrm{~g}$.

\section{Philemon novaeguineae jobiensis Meyer.}

Philemon jobiensis A. B. Meyer, Sitzungsber. Ak. Wiss. Wien, lxx, p. 113 (1874-Jobi).

Half a dozen specimens from Ifaar, near Lake Sentani, September 1928.

"Iris brown or dull grey." Wings ô 155-161, 우 155-158 mm.

Weight ô 140-160, ㅇ 127,140 g. !

Five subspecies are recognizable on New Guinea and Aru Islands. Grant, Ibis Supplement, p. 78, expressed doubt in the differences of these forms, but without reason. Stresemann, in his Sepik article, p. 64, recognized them all.

70. Philemon (Philemonopsis) meyeri Salvad.

Philemon meyeri Salvadori, Ann. Mus. Civ. Genova, xii, p. 339 (1878-Rubi).

우 Hollandia, 16.x. 1928.

Weight $45 \mathrm{~g}$.

우 Cyclops Mountains, 2.ix.1928.

Weight $42 \mathrm{~g}$.

"Iris dark brown-grey or brown."

71. Timeliopsis fulvigula fulvigula (Schleg.).

Euthyrhynchus fulvigula Schlegel, Nederl. Tijdschr. Dierkunde, iv, p. 40 (1871-Arfak region).

One male, head shot to pieces, mountains near Ditschi, 31.v.1928. " Iris red-brown, bill black, feet greyish brown."

Weight $16.5 \mathrm{~g}$. Wing $78 \mathrm{~mm}$.

This form, from which T.f. meyeri (Salvad.), of S.E. New Guinea is doubtfully distinct, is very rare in collections.

In the Ibis Suppl. 1915, p. 79, Ogilvie-Grant called this bird Timeliopsis flavigula meyeri, instead of $T$. fulvigula meyeri!

\section{Timeliopsis griseigula (Schleg.).}

Euthyrhynchus griseigula Schlegel, Nederl. Tijdschr. Dierkunde, iv, p. 39 (1871-Sorong and near west coast of Geelvink Bay).

ô Hollandia, 15.x. 1928.

This specimen agrees with a male from Takar, collected by Doherty, and fairly well with one from Andai (Arfak), though the latter is more reddish and brighter, but that may be due to individual variation. Wing $96 \mathrm{~mm}$. 
I used the name griseigula, though there is no grey (" gris rougeatre très pâle "), but this is not mentioned in the description by Salvadori, who had two Andai examples, and who had examined the Leiden specimens. I cannot call the bird flavigula because the wing is supposed to be only $80 \mathrm{~mm}$., which is too little for any "griseigula."

Perhaps flavigula is the same!

73. Cinnyris jugularis frenata (S. Müll.).

Nectarinia frenata S. Müller, Verh. Nat. Gesch., Land-en Volkenkunde, p. 173 (1843-Lobo, New Guinea).

2 of ad. and 1 \& Manokwari, one female, Ifaar.

The eastern subspecies is well marked and is now called Cinnyris jugularis flavigastra (Gould), originally described from New Ireland.

One female was weighed : $7 \cdot 5 \mathrm{~g}$.

\section{Cinnyris sericeus sericeus Less.}

Cinnyris sericeus Lesson, Dict. Scienc. Natur. i, p. 21 (1827-Dorey).

Manokwari, Hollandia and Ifaar.

Weight ô $8-9 \mathrm{~g}$.

75. Dicaeum geelvinkianum simillimum subsp. nov.

Extremely similar to D. g. diversum R. \& H. (Nov. Zool. 1903, p. 215), but differs by the deeper red colour of the erown, breast patch and rump. Type: ô ad. Hollandia, 1.viii.1928. No. 1690 E. Mayr coll.

Weight $6 \mathrm{~g}$.

With this specimen agrees a male from "near Humboldt Bay," received from J. Dumas.

With the type of diversum agrees the series from the southern Snow Mountains, and a female from Takar, north coast of New Guinea, has the crown lighter than in adult females of rubrocoronatum, so that I consider it to belong to diversum, and not to simillimum.

It is perhaps risky to describe a form which differs so little, but this form is interesting as standing in between rubrocoronatum and diversum, in having the deep red of the former and the more steel-blue (not purplish) edges of the latter, and its geographical position is equally intermediate.

76. Dicaeum pectorale S. Müll.

Dicaeum pectorale S. Müller, Verh. Nat. Gesch. Ned. Ind., Land-en Volkenkunde, p. 162 (Lobo).

A small series from Siwi, above Wasior, and Manokwari, also one of ad. from Wondiwoi, Wandammen Peninsula. ${ }^{1}$

Weight oิ $7 \cdot 5-8,+7 \cdot 5 \mathrm{~g}$.

\section{Melanocharis bicolor bicolor Rams.}

Melanocharis bicolor Ramsay, Proc. Linn. Soc. N.S. Wales, iii, p. 277 (1879-" Goldie River, British New Guinea ").

Ten adult males and some adult females, with enlarged ovaries, were collected near Hollandia and on the Cyclops Mountains in August and October.

1 What is Dicaeum arfakianum Finsch, Notes Leyden Museum, xxii, p. 70 (1900-supposed Moris, Arfak Mountains), described from one skin at Leiden, with a brownish grey crown, yellow tufts on the sides of the breast, and a wing of $62 \mathrm{~mm}$.! Dr. Mayr considers it to be an Acmonorhynchus with wrong locality ! 
"Iris brown, bill and feet black." The males are blue-black above and below, females above olivaceous-green, underneath grey with an olive-greenish wash. Wings ô $63-67$, mostly $64-66$, ㅇ $61-65$, mostly $62-64 \mathrm{~mm}$.

Weight ô $10-12$, ㅇ $13 \cdot 5-16 \cdot 5 \mathrm{~g}$.

\section{Melanocharis nigra nigra (Less.).}

Dicaeum niger Lesson, Voy. Coquille, Zool. i, p. 673 (1828-Dorey, now called Manokwari).

Two males Siwi, May 1928. Weight 12 and 13 g. " Iris dark grey-brown." This bird is not very numerous in collections, and I should say it would be impossible to distinguish it in the trees from Melan. ("Urocharis") longicauda. In our Notes on Papuan Birds Lord Rothschild and I mixed this bird up with $N$. longicauda, but in Nov. ZooL. 1907, p. 476, we put ourselves right and stated the differences between males and females of the two species.

\section{Melanocharis longicauda Salvad.}

Melanocharis longicauda Salvadori, Ann. Mus. Civ. Genova, vii, p. 942 (1875-Arfak).

A series was obtained near Siwi, Ditschi, Lehuma, and two at Wondiwoi. "Iris ô brown, q greyish brown."

Weight of 11-13, ㅇ 13, 14.5, $15 \mathrm{~g}$. Loranthus was found in one stomach.

I do not consider the more emarginated first primary and the tail, which is some millimetres longer, useful generic characters, and therefore unite " Urocharis" (type longicauda) unhesitatingly with Melanocharis.

\section{Pristorhamphus versteri versteri Finsch.}

Pristorhamphus versteri Finsch, Proc. Zool. Soc. London, 1875, p. 642 (Arfak).

ฮึ우 Dohunsehik (Issim valley), 17.vi.1928.

Kofo (Anggi lakes), 13.vi.1928.

3 ô, 2 ô juv., 6 q mountains above Ditschi, May.

Adult males, juvenile males and many females from the Cyclops Mountains, September and August. " Iris dark brown." The two forms which Rothschild and I separated in Bull. B.O. Club, xxix, p. 36, are very good. It may be added that the back of $P . v$. versteri and $P . v$. maculiceps DeVis is in the adult male much more glossy than in $P$. v. meeki and that the abdomen of $P$. v. meeki is darker in the middle than in $P . v$. versteri, of which we had only two poor males and a female.

The larger body, bill, wings and shorter tails of the females of Pristorhamphus have been noted by most writers. The young males are like the females but they have more black in the tails and are easily distinguished by the narrower, smaller bills and shorter wings.

Weight $\hat{o}$ ad. $10 \cdot 25-13 \cdot 5 \mathrm{~g}$, ㅇ 16-17.5 g.

\section{Oreocharis arfaki (Meyer).}

Parus (?) arfaki A. B. Meyer, Sitzungsber. Isis, Dresden, 1875, No. of April 1 (Arfak).

Four males Lahuma (Arfak) and Kofo (Anggi gidji), June 1928. " Iris dark, bill black, feet blackish."

Weight $18 \cdot 5-20 \mathrm{~g}$. 
82. Zosterops minor A. B. Meyer.

Zosterops albiventer minor A. B. Meyer, Sitzungsber. Akad. Wiss. Wien, lxx, p. 115 (1874-Jobi).

1 ô ad. Cyclops Mountains, 27. viii.1928. Testes large.

Weight $10 \cdot 5 \mathrm{~g}$.

This species (minor Mey. 1874, aureigula Salvad. 1878) was formerly only known from Jobi, but Bürgers discovered it on the mountains of the Sepik region, and now one was sent from the Cyclops Mountains. It agrees with our five Jobi specimens except that the orange-yellow throat appears less restricted ; but this is apparently due to preparation, the throat in the Cyclops Mountain skin being too much contracted, those of the Jobi specimens very much elongated.

\section{Zosterops chrysolaema Salvad.}

Zosterops chrysolaema Salvadori, Ann. Mus. Civ. Genova, vii, p. 954 (1880-Arfak).

$1 \hat{\jmath}, 1$ \& Siwi. "Iris bleich grau-braun. Schnabel schwarz. Füsse dunkelgrau."

ô Weight $\hat{\jmath} 11 \mathrm{~g}$.

\section{Zosterops novaeguineae Salvad.}

Z. novaeguineae Salvadori, Ann. Mus. Civ. Genova, xii, p. 341 (1878-Arfak).

6 ô 0 ad. and two juveniles with fluffy plumage and paler yellow throats, Siwi, Arfak, 23.iv. 1928.

One male from Wokan, Aru Islands, appears to be duskier, darker on the sides of the head, but a series would be necessary to confirm this !

Weights 1 ơ $10 \cdot 5,1$ \& $10 \cdot 5 \mathrm{~g}$.

\section{Zosterops fuscicapilla Salvad.}

Zosterops fuscicapilla Salvadori, Ann. Mus. Civ. Genova, vii, p. 955 (Arfak).

Four Siwi, Arfak, three Cyclops Mountains. "Iris brown. Bill black. Feet grey."

Weight ô $11 \cdot 5-12 \cdot 5$, ㅇ $12-12 \cdot 5 \mathrm{~g}$.

\section{Pachycare flavogrisea flavogrisea (A. B. Meyer).}

Pachycephala flavogrisea A. B. Meyer, Sitznugsber. k. Akad. Wissensch. Wien, lxix, p. 495 (1874Arfak).

A fine series from Siwi, Ninei, and three from Wondiwoi.

Weight ô $17 \cdot 35-19 \cdot 5$, 우 $18 \mathrm{~g}$.

The Wondiwoi specimens are very bright, more orange yellow, but they are not so orange as $P . f$. subaurantia, though the orange yellow on the underside and face differs somewhat in brightness. It seems that this colour fades, as seven old skins, collected in 1874 and 1879 in the Arfak Mountains by Bruijn's hunters, are paler than our fresh material. There can, however, be no doubt that the birds from S.E. New Guinea are paler than the Arfak ones and they also differ in having finer, less bulky bills. The wings of the S.E. New Guinea specimens are also on an average shorter, ranging from 63 to 66 , very nearly 67, while in Arfak the wings are 66 to 67 , rarely $68 \mathrm{~mm}$. I therefore name the S.E. Papuan form

Pachycare flavogrisea subpallida, subsp. nov.

Type: $\widehat{o}$ ad. Bihagi, head of Mambare River, 28.iii.1906. A. S. Meek coll. (Eichhorn praep.). No. A. 2670 Meek coll. 
There can be no doubt (though a few specimens are wrongly sexed on the labels) that the specimens with a dusky patch on the ear-coverts are females ; they are also smaller, wings $3-4 \mathrm{~mm}$. shorter, than males. A young female of subaurantia is paler underneath than the adult, the forehead quite pale and there is no black cross-bar across the forehead behind the yellow line, the bill is much shorter.

Specimens from the Aicora River in N.W. British New Guinea, and a female from the Rawlinson Mountains seem somewhat intermediate between subpallida and flavogrisea, but to belong to subpallida.

It seems that the yellow colour in skins is subject to fading in time, as old skins are apparently faded, compared with fresh ones.

\section{Pachycephala schlegelii schlegelii Schleg.}

Pachycephala Schlegelii Schlegel (name ex Rosenberg MS.), Nederl. Tijdschr. Dierkunde, iv, p. 43 (1873-Interior of Arfak Peninsula).

Both sexes from the mountains above Ditschi and Lehuma, Arfak Peninsula, also series of both sexes from Wondiwoi, Wandammen Peninsula.

The series from the Arfak Peninsula agrees perfectly with those from Wondiwoi. Some young birds have traces of the red-brown first juvenile plumage on the head and wing-coverts.

Unfortunately many of this form and the following were moulting their body plumage.

88. Pachycephala schlegelii cyclopum subsp. nov.

ô ad. In coloration like $P$. s. schlegelii, but bill as a rule larger, higher, wings longer.

o ad. Like that of $P$. s. schlegelii, but upperside somewhat more greenish, less brownish, wings longer, chest paler grey, followed by a paler band.

Wings $P$. s. schlegeli ô ad. : $86,85,85 \cdot 5,85,87,86,87,84,84,85,87 \cdot 5,85$ $(84-87 \cdot 5) \mathrm{mm}$. Weight $19 \cdot 5-24 \cdot 5 \mathrm{~g}$.

P. s. schlegeli + ad. : $80,85,86,86,85,85,85,81,81,84,83,83,81,81$, $82 \cdot 5$ (80-86) $\mathrm{mm}$. Weight $19 \cdot 5-25 \mathrm{~g}$.

P. s. cyclopum Hart. ô ad. 88, 91, 90·5, 91, 91·5, 89.5, 90, 88.5, 89.5, 90, 88, $89,91(88-91) \mathrm{mm}$. Weight $23 \cdot 5-26 \cdot 5 \mathrm{~g}$.

P. s. cyclopum 우 ad. : $87,87 \cdot 5,88,87,87,87,89,90,90,89 \cdot 5,87(87-90) \mathrm{mm}$. Weight 24-26.5 g.

Type: + Cyclops Mountains 31.viii.1928. No. 2123 Ernst Mayr coll.

\section{Pachycephala meyeri Salvad.}

Pachycephala meyeri Salvadori, Aggiunte Orn. Pap. ii, p. 104 (1890-Hatam, Arfak Mts. Type in Mus. Dresden, compared by me with Mayr's specimens 8.ii.1930).

As far as I know only the two specimens (unfortunately for many years mounted in the glass-cases and therefore now dirty, the throats brownish grey) in Dresden were hitherto known. They are both females. Now Mayr sent a male and female adult from the mountains near Siwi, 21 iv. 1928 and 13.v.1928, and an apparent young male from Ditschi. The sexes are alike.

The crown is slaty grey, rest of upperside olive-green, throat greyish white with faint dusky tips to the feathers, a pale brown chest-band; abdomen and 
under tail-coverts bright lemon yellow, under wing-coverts and axillaries very pale yellow. "Iris brown. Bill black. Feet grey." Wing $90 \mathrm{~mm}$.

Weight of $19 \mathrm{~g}$.

\section{Pachycephala griseiceps squalida Oust.}

Pachycephala squalida Oustalet, Bull. Soc. Philomatique septième série, ii, p. 56 (Publ. 1878-1 우 young from Amberbaki, north coast of Berau or Arfak Peninsula).

A series from Siwi, $800 \mathrm{~m}$., in the Arfak Mountains must, I think, belong to this subspecies. The throat is whitish and in the very cleanly and smoothly made skins the throat is mostly very distinctly striated with pale grey, but sometimes the streaks are hardly visible, and in skins where the throat is a bit ruffled the streaks cannot be seen. ${ }^{1}$ The abdomen is pale sulphur yellow. Wing $\hat{o}$ (5) $81-83$, once 85 , ㅇ $78-80$, once 81 , once $74 \mathrm{~mm}$.

Weight $\hat{0}+$ 1 $18-23 \mathrm{~g}$.

"Iris dark brown, bill black, feet grey." The line from base of upper bill to eye is distinctly brownish white, ear-coverts brown and whitish.

The forms of $P$. griseiceps are somewhat difficult to define, not only, though mainly, on account of want of well-collected and sufficient series ; unfortunately few skins came to hand as perfect and smooth as those of Albert Eichhorn.

We have now before us the following forms :

Pachycephala griseiceps griseiceps Gray, 1858, Aru.

We have specimens from various islands of the Aru group, but all in worn plumage; the streaks on the throat are very faint, but clearly present in at least some specimens. With the Aru birds seem to agree those from the Aroa River in S.E. New Guinea, though it is possible that they differ slightly if equally good material was at hand from the Aru Islands.

\section{Pachycephala griseiceps squalida Oust., 1878, Amberbaki.}

Except the Arfak specimens those from Misol, Sorong and Waigiu seem to belong to this form, though it is possible that the latter are less clearly striated on the underside, but at present this cannot be said with certainty. The Misol specimens have the brown chest-band very pronounced (more like Aru birds, i.e. typical griseiceps).

\section{Pachycephala griseiceps jobiensis Meyer, 1874, Jobi.}

Underside undoubtedly slightly brighter yellow, at least on abdomen and under tail-coverts, striations on throat and breast absent or only faintly indicated. Ear-coverts brown. We have this form from Jobi Island, but we cannot distinguish from the Jobi skins those from Kapaur (Fakfak) on the southern part of the Onin Peninsula. This is, as far as our present knowledge goes, not a satisfactory distribution, but it may be that this form is one of the plains and much wider spread than we know.

(P. griseiceps rubiensis Meise, Abh. \& Berichte Mus. Tierkunde, Dresden, xvii, No. 4, p. 15, 1929, is indistinguishable from jobiensis. Compared with

1 Monsieur Berlioz kindly tells me that in the type of squalida the throat and breast are in bad condition, and that he cannot see any trace of stripes; I think nevertheless that our specimens from the Arfak region are the same, as sometimes the stripes are practically absent, and in bad skins they would be invisible. 
squalida it is not more intensively yellow underneath, and the edge of the wing is of the same colour. Described from one old skin, compared with one Andai specimen!)

\section{Pachycephala griseiceps subflavidior subsp. nov.}

Very similar to $P$. g. jobiensis from Jobi, but abdomen and especially under tail-coverts brighter yellow, the latter brightest. The whitish line from bill to eye is hardly indicated, ear-coverts brown!

This form replaces jobiensis on the north coast east of Geelvink Bay, at Takar and the Cyclops Mountains and Hollandia.

Ernst Mayr sent a series of nine from the latter two places.

Weight $19 \cdot 5-23 \mathrm{~g}$.

Type: $q$ ad. Cyclops Mountains 23. viii.1928. No. 1959 Mayr coll.

Pachycephala griseiceps perneglecta subsp. nov.

The specimens from the southern Snow Mountains differ by the dark and distinct striations not only on the throat and breast, but even along the abdomen. There is a distinct greyish brown band across the chest and the superciliary line from bill to over the eyes is distinct and dirty whitish. Ear-coverts brownish, not striated. Abdomen and under tail-coverts very pale yellowish. Wings of of to 85 and $86 \mathrm{~mm}$.

Type: ô ad. Snow Mountains, 26.x.1910. No. 4903 A. S. Meek coll., skinned by A. Eichhorn.

Pachycephala griseiceps miosnomensis Salvad. 1879, Miosnom.

We do not possess a specimen of this long-winged form, but a similarly large subspecies inhabits the small island south-west of Waigiu, called Gagi. Both have the wings about $90 \mathrm{~mm}$. or more and are generally larger.

$(P$. dubia I cannot confidently regard as a subspecies of griseiceps, as it occurs in many places in S.E. Papua, also on the Hydrographer Mountains, while $P$. griseiceps is found there at Naiabui, Kotoi district, and Aroa River.)

\section{Pachycephala hyperythra hyperythra Salvad.}

Pachycephala hyperythra Salvadori, Ann. Mus. Civ. Genova, vii, p. 932 (1875-Arfak Mts. and Kapaur).

13 oิำ ad. from Siwi, Arfak Mountains, 1 ô Ninei, + juv. mountains near Ditschi, 1 ô Wondiwoi.

Weight $25-29 \cdot 5$, one $+33 \cdot 75 \mathrm{~g}$ !

The males have the upperside less rufous, more yellowish than the females, the edges to the primaries a shade less reddish. "Iris dark brown, bill blackish, feet greyish pink, flesh-colour." The young bird has the edges of some of the upper wing-coverts and outer edges to the quills rufous-chestnut, and the bill in our specimen is (in skin) light, not blackish, the throat not so white, more yellowish.

\section{Pachycephala rufinucha rufinucha Scl.}

Pachycephala rufinucha Sclater, Proc. Zool. Soc. London, 1873, p. 692 (Hatam).

Half a dozen from the mountains above Ditschi, about 1,500 feet, end of May and June. Two from Lehuma. "Iris hellbraun, blass graugelblich, milchkaffeefarbig. Schnabel schwarz.” Wing ô $90,90,92$ (one 87 might be + ), ㅇ $86,87,89,88 \mathrm{~mm}$. 
Weight ô 36 , ㅇ $35,41 \mathrm{~g}$.

The forehead is grey without black centres to the feathers. There is no blackish chin-spot.

This species is also somewhat short-tailed, and if $P$. hattamensis is generically separated as Pachycephalopsis, then rufinucha must either be united with the latter, or receive another generic or subgeneric name. The bright rufous colour of the young shows, however, the close relationship to other species of Pachycephala. (Voice and habits of rufinucha prove the Pachycephala-relationship, while hattamensis is something quite different.-E. Mayr.)

\section{Pachycephala rufinucha niveifrons subsp. nov.}

This form agrees with $P$. r. gamblei in having the much larger chestnut nuchal patch and dark centres to the frontal feathers, but the latter are purer snow-white, and the sides of the body are darker olive-green, also the upper surface is a shade darker and greener. Wings of 86, f $84,86 \mathrm{~mm}$.

Weight ô 43 , ㅇ $40,40 \mathrm{~g}$.

Type : $\widehat{o}$ ad. Wondiwoi Mountains, Wandammen, 11.vii.1928. No. 1465 Ernst Mayr coll.

$1 \hat{0}, 2$ 의 from the Wondiwoi Mountains. With these birds agree in every detail the seven skins collected by A. S. Meek on Mount Goliath in January and February 1911.

There is a curious variation in the colour of the iris in P. rufinucha. The three Wondiwoi specimens have the iris marked: " o gelblichgrau, of dunkelbraun." The Mount Goliath birds : o "Light yellowish brown, light yellowish white, silvery grey (several); + pale chocolate, silvery grey, brown." The P. r. gamblei from S.E. New Guinea: ô light brown (several), silvery brown, dull yellow, silvery grey, light reddish brown; + silvery grey, brown, light brown (several). (P. r. rufinucha, see under that heading.)

\section{Pachycephala pectoralis soror Scl.}

Pachycephala soror Sclater, Proc. Zool. Soc. London, 1873, p. 692 (Arfak).

Mountains near Siwi and Ditschi, Ninei.

ô ad. "Iris brown. Bill black. Feet grey."

Weight ô 25-26, 우 24-27 g.

These specimens are of course typical soror. Ogilvie-Grant correctly separated what used to be called soror into three forms, differing by the coloration of the rectrices, soror from the Arfak Mountains, klossi from the Snow Mountains, bartoni from S.E. New Guinea; though these are very close to each other, they must be distinguished. A more difficult question is if these forms are subspecies of pectoralis or if they form a separate species.

(Dr. Stresemann's reasons for not considering them subspecies of pectoralis are perhaps not valid. Neither the occurrence of an Australian subspecies in the lowland of Naiabui, S.E. New Guinea, where P. soror has never been recorded, nor the fact (if universally established) that soror is a mountain bird, while the forms of pectoralis inhabit the lowlands, reflect on the status of soror as a species or subspecies of pectoralis.) 
96. Pinarolestes megarhynchus megarhynchus (Quoy et Gaimard).

Muscicrpa megarhymcha Quoy et Gaimard, Voy. Astrolabe, Zool. i, p. 172, pl, iii, fig. 1 (1830-Dorey, Arfak Peninsula).

Ernst Mayr sent a nice series from Siwi (in the mountains S.E. of Anggi Lakes) Mountains near Ditschi, Manokwari (Dorey), and Wondiwoi (Wandammen). The males and females have a dark horn-brown bill! Wings ô 94-102, 우 $92-94 \mathrm{~mm}$..

Weight ơ $34-37 \cdot 5$, 우 $36-37 \mathrm{~g}$.

\section{Pinarolestes megarhynchus obscurus (Mey.).}

Rectes obscura A. B. Meyer, Sitzungsber. k. Akad. Wiss. Wien, 1874 (Ansus, Jobi Island).

$11 \hat{\jmath}, 1$ o Hollandia (Humboldt Bay), Hol, Cyclops Mountains, Ifaar near Lake Sentani.

Weight of nine males $35-40 \mathrm{~g}$. Testes of some large.

This form belongs to the group in which the males (at least the adult ones) have black bills, while in the females they are brown.

Comparing these specimens with our poor series of badly made skins from Jobi (Ansus), I cannot confidently separate them. Dr. Meise separated the north coast form under the name of hybridus (Abh. u. Ber. Mus. f. Tierkunde, Dresden, xvii, No. 4, p. 17, 1929) from obscurus, but he had only one bad skin from the Tring Museum, from Tana Mera, collected by William Doherty. I do not admit it for the time being ; it was certainly premature and probably wrong to separate this form on such meagre evidence, especially as one from the Mamberano River does not agree with the type of "hybridus."

Wings of Mayr's specimens: ô $99,99 \cdot 5,99,98,100 \cdot 5,100,95$; 우 95, 95 $\mathrm{mm}$. The 95 ô has a black bill. Some specimens in September and October moult wings and body feathers.

Pinarolestes megarhynchus has many subspecies, and I agree with Meise, who includes in this species also the greyish forms, obscurus, etc., with blackbilled adult males.

Pinarolestes megarhynchus misoliensis Meise 1929 is a very distinct form with pale underside, bill ô pale brown.

Very close to aruensis, only underside still paler, as a rule.

Pinarolestes megarhynchus batantae Meise 1929 is very closely allied to $P$. m. megarhynchus, but the upperside slightly more olivaceous, less rufescent. Edges of quills not olivaceous. Bill of male as in females, brown.

Pinarolestes megarhynchus affinis of Waigiu is very distinct, having an olivaceous grey underside without rufous.

Pinarolestes megarhynchus aruensis (Gray) 1858. Pale underside but still more reddish than the very pale misoliensis. Bill of both sexes brown.

Pinarolestes megarhynchus tappenbecki (Rchw.) 1899 from the Sepik to the Astrolabe Bay is very similar to $P . m$. megarhynchus, but usually the upper throat darker and more grey. Bill also in male brown.

Pinarolestes megarhynchus madaraszi R. \& H. 1903 from N.E. Papua ("Kai Peninsula") is smaller than tappenbecki, and the male has a black bill.

Pinarolestes megarhynchus maeandrinus Stres. 1921. Underside paler than in tappenbecki and madaraszi, bill adult male blackish. 
About other subspecies, see Nov. Zool. 1903, and Stresemann, Archiv f. Naturg. vol. 89, 1923, p. 76 .

[For twenty years we had in the Tring Museum a Pinarolestes shot by one of Albert Meek's men at Merauke in South New Guinea, east of the Marianne Strait and Frederik Hendrik Island. This specimen does not agree with any of the known New Guinea subspecies of Pinarolestes megarhynchus, but the upperside is more reddish than any specimen in the large series of $P$. megarhynchus rufogaster (and gouldi, if the latter is separable), mostly from the Mathews collection.

That this new form is nearer to the Australian ones than to any of the New Guinea races is very interesting, as the Merauke plains show a striking faunal affinity to Australia. In the list of a poor and badly prepared and labelled collection from Merauke listed by Bangs and Peters in the Bull. Mus. Comp. Zool. Harvard, lxvii, 1926, p. 421, and in Dr. van Oort, Nova Guinea, 1909, about half a dozen birds are mentioned from Merauke, which are otherwise only known from Australia! Unfortunately the region of Merauke is very imperfectly known.

I call the Merauke form

Pinarolestes megarhynchus goodsoni subsp. nov.

after my faithful assistant Arthur Goodson, who has helped me comparing Mayr's Papuan collection.

Type: ô ad. Merauke, 4.vi.1910. "Iris light brown. Bill horn colour. Feet dull pinky shade.']

\section{Pitohui nigrescens nigrescens (Schleg.).}

Rectes nigrescens Schlegel, Ned. Tijdschr. Dierk. iv, p. 46 (1871-Arfak Mts.).

3 ô Lehuma, Arfak Mountains, 1 ô Kofo (Anggi gidji), 11.vi.1928.

1 ô Dohunsehik, 1,400 m., 17.vi.1928.

3 우 Lehuma, 1.vi.1928.

The females are of the typical coloration, the upperside dull rufous-brown, crown generally with a distinct grey tinge, underside much paler and as a rule with a faint, greyish tinge on the abdomen. The adult males are slaty-black, the bill black. Younger males are bright ochraceous underneath and have the bill not black, later on the upper bill becomes black, the lower mandible whitish.

Weight ô $58-72$, ㅇ $65,66 \mathrm{~g}$.

\section{Pitohui nigrescens wandamensis subsp. nov.}

1 ô, 1 ㅇ Wondiwoi, 9. vii. and 14. vii.1928. The male agrees in every way with that of $P$. nigrescens nigrescens, except that the abdomen is a little deeper and purer black, but the female is deeper rufous brown above and below the crown like the back, the underside brighter and more rufous on the lower throat.

Type: + ad. Wondiwoi. No. 1410 Mayr coll.

The two females from the Weyland Mountains are less bright than the type of meeki, but not so dark as wandamensis.

Weight ô $73 \cdot 5$, ㅇ $68 \cdot 5 \mathrm{~g}$. 
100. Pitohui dichrous dichrous (Bp.).

Rectes dichrous Bonaparte, Compt. Rend. Acad. Paris, xxxi, p. 563 (1850-Lobo, from Salomon Müller).

5 ㅇa․, 1 ô juv., Siwi, April-May 1928.

4 ô Wondiwoi, Wandammen, 17.vii.1928.

ડํㅜ Hollandia, 3. viii. 1928, 2 우 October.

16 §̊ำ Cyclops Mountains, August 1928.

ơo Ifaar, September 1928.

The iris is marked as red and red-brown, in one case as grey-brown.

Weight, 63-80, mostly about $68-73 \mathrm{~g}$.

The sexes are alike in colour, and so are the young, but the plumage of the latter is more fluffy and more silky. Wing ô 107-112, ㅇ $102-106 \mathrm{~mm}$., a " ô" with $105 \mathrm{~mm}$. is perhaps wrongly sexed.

End of August sexual organs began to get much enlarged, but by no means in all individuals.

\section{Pitohui kirhocephalus kirhocephalus (Less.).}

Lanius kirhocephalus Lesson, Voy. Coquille, Atlas, pl. xi (1827-New Guinea, collected by Lesson near Dorey, Arfak Peninsula, see Voy. Coquille, Atlas, i, 2, p. 633).

1 ô, 3 우 Manokwari, 9.-10.iv. 1928.

2 oै (?), 1 ㅇ, 1 unsexed Momi (Wariap), April and June 1928.

Males darker on back and head, throat and abdomen, bill darker (" blackish "), in female " reddish grey."

There is some variability in these birds, apparently not entirely dependent on sex.

A "ㅇ" from Mount Moari, in the Berau Peninsula (near Oransbari), 3,000 feet, collected by J. M. Dumas, appears to belong to this form, also an unsexed bird, but obviously + , from Etna Bay, taken 3. viii.1896, which agrees much better with kirhocephalus than with decipiens which should range to Etna Bay, according to Stresemann.

Weight ô 81, ㅇ $74,77,85 \mathrm{~g}$.

\section{Pitohui kirhocephalus dohertyi R. \& H.}

Pitohui dohertyi Rothschild \& Hartert, Nov. Zool. x, p. 95 (1903-Ron Island, just north of the Wandammen Peninsula, Geelvink Bay).

11 ô, 10 ㅇ Wasior, coast of Wandammen Peninsula, 20.-31.vii.1928. Agree perfectly with the Ron specimens.

ơt iris dark brown, bill and feet black.

While the males are all black-headed, the females vary from dark grey, almost black, to a dull ashy grey, and some such specimens are hardly separable from some decipiens, though the latter, in the series, are different.

Weight ô 95-103, + $90 \cdot 5-102$ g. Wings ô 118-128, mostly 122-123, ㅇ 117-123 mm.

103. Pitohui kirhocephalus meyeri R. \& H.

Pitohui meyeri Rothschild \& Hartert, Nov. Zool, x, p. 96 (1903-Takar, Tana Mera).

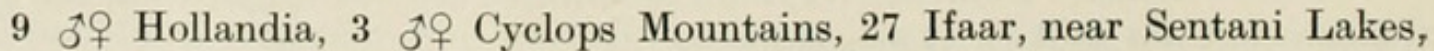
September 1928. 
Bills always brownish in skin, marked as reddish grey, greyish-red, fleshy. Iris dark brown.

Weight ô $73-79$, 우 68-80 g !

Younger birds are paler on the underside, but variable.

104. Pitohui ferrugineus ferrugineus (Bp.).

Rhectes ferrugineus Bonaparte, Compt. Rend. Acad. Paris, xxxviii, p. 536 (1850-Ex Müller in Mus. Lugd., from Lobo).

1 Manokwari, 4 Siwi and mountains above Siwi, 1 Wasior, 2 Hollandia, 3 Cyclops Mountains, 2 Ifaar.

All these differ somewhat individually in the tint of coloration, but no local forms can be separated.

The iris is marked as cream-colour, twice as café au lait, bill black, feet light grey, or lead-colour.

Weight $83-100 \mathrm{~g}$.

\section{Pitohui cristatus cristatus (Salvad.).}

Rectes cristata Salvadori, Ann. Mus. Civ. Genova, vii, p. 930 (1875-Mt. Morait in West New Guinea).

2 ô, 3 우 Siwi, Arfak Mountains.

The young bird has the bill smaller and not black, but brownish. Plumage the same in colour.

Iris dark brown, or brown.

Weight ô ad. 103-111.5, 우 $97 \mathrm{~g}$.

106. Pitohui cristatus arthuri subsp. nov.

Differs from $P$. c. cristatus in having the crown of the head lighter and not so deep rufous brown, but almost olivaceous brown, the whole back, scapulars, wing-coverts and outside of wings more olivaceous brown, less deep rufous brown. Wings ô 126, 우 $118 \mathrm{~mm}$.

Weight 104 and $100.5 \mathrm{~g}$.

ઈิํํ Cyclops Mountains, 22 ., 23. viii. 1928. Type ô No. 1962 Ernst Mayr coll.

Named after Mr. Arthur Goodson, who has greatly helped me with the working out of Dr. Mayr's collection.

There are three subspecies of Pitohui cristatus:

1. P. cristatus cristatus (Salvad.) West Papua. Exact distribution uncertain, but apparently Berau Peninsula to Lower Snow Mountains.

2. P. cristatus brunneiceps (Ramsay).

? Rhectes (Oreoica ?) brunncipes ${ }^{1}$ Ramsay, Proc. Linn. Soc. N.S. Wales, iv, p. 467 (1879-Goldie

River, S.E. Papua, 30 miles inland).

S.E. New Guinea. Upperside as in P. c. cristatus, but underside beyond the dark rufous jugulum much paler, ochraceous-buff, to almost buff.

\section{Craticus cassicus (Bodd.).}

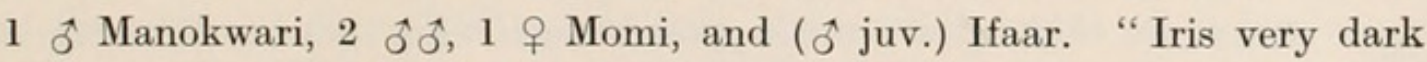
brown."

Weight adult $150-165 \mathrm{~g}$.

1 Obvious misprint for brunneiceps. 


\section{Craticus quoyi quoyi (Less.).}

$1 \hat{\jmath}$ Wasior and $1 \hat{\jmath}, 1$ ㅇ Hollandia.

Weight of a male $170 \mathrm{~g}$.

\section{Gerygone palpebrosa palpebrosa Wall.}

Gerygone palpebrosa Wallace, Proc. Zool. Soc. London, 1865, p. 475 (Aru Islands).

Siwi and mountains near Siwi, both sexes. Iris red or red-brown.

Weight ô 8-9 $\mathrm{g}$, 우 7-8 g. River !

On the south coast this form, not wahnesi, extends to Avera on the Aroa

The shape of the white line is easily altered by preparation, being more like a round patch, when the neck is made short and thick, line-like and narrower, when the neck is long and thin.

\section{Gerygone palpebrosa wahnesi (Mey.).}

Pseudogerygone wahnesi A. B. Meyer, Orn. Monats'er. 1899, p. 144 (Bongu, German New Guinea).

$\hat{o}$ Hollandia, ô Cyclops Mountains, August 1928. Iris red.

Weight as in G. p. palpebrosa.

We have this excellent subspecies, which differs in its dusky black crown, now from Simbang (Wahnes), Kumusi River (Meek), and Hydrographer Mountains (Eichhorn). The underside in these is not paler than in G. p. palpebrosa, except in the Jobi example, which is paler underneath.

Another subspecies is G. palpebrosa personata Gould 1866 from Australia, in which the black of palpebrosa is replaced by brown. I am obliged to Arthur Goodson, who called my attention to this relationship.

\section{Gerygone cinerea Salvad.}

Gerygone (?) cinerea Salvadori, Ann. Mus. Civ. Genova, vii, p. 958 (1875-Arfak Mts.).

ํㅜㅇㅜ Mountains above Ditschi, June 1928.

ㅇ Mount Wondiwoi, 1,000 m., 17.vii.1928.

ㅇ Mount Lahuma, 1.vi.1928. "Iris chestnut-brown."

Sexes alike.

Weight $6-7 \mathrm{~g}$.

\section{Gerygone chloronota cinereiceps (Sharpe).}

Pseudo-gerygone cinereiceps Sharpe, Nature, xxxiv, p. 340 (August 12, 1886-Astrolabe Mts., S.E. New Guinea).

Gerygone placida Madarász, Orn. Monatsber. viii, p. 3 (1900-Sattelberg).

ô Siwi, 24.iv. 1928. Iris brown, bill and feet black.

Weight $6 \cdot 5 \mathrm{~g}$.

G. placida is a synonym, and Stresemann, in litt., now quite agrees with me that it is not separable.

G. cinereiceps is a subspecies of the North Australian chloronotus (1842), from which it differs, however, in the more greenish, less yellowish, upperside. G. chloronota darwini Mathews, Austral Avian Rec. i, 2, p. 4 (1912-N.W. Australia) is a synonym of chloronotus; the supposed longer wing is due to Mathews having only females from the Northern Territory, and the head is not lighter as a rule. G. chloronota apsleyi Mathews, l.c., from Melville Island is also a synonym, as there is no constancy at all in the supposed darker head and greener back. 


\section{Gerygone chrysogaster Gray.}

Gerygone chrysogaster G. R. Gray, Proc. Zool. Soc. London, 1858, p. 174 (Aru Islands).

1 ㅇ Cyclops Mountains, 21.viii.1928. "Iris brown, bill black, feet pale yellowish grey."

Weight $7 \cdot 5 \mathrm{~g}$.

The sides of the head are somewhat greyish, the crown perhaps more greyish than the back.

[It seemed to me, after comparing our fine series from various parts of New Guinea and the Aru Islands and Jobi, that a northern form from Jobi and the north coast of New Guinea could be separated from the typical one from Aru to the foot of Snow Mountains and S.E. New Guinea, as among the former there were some lighter heads. It seems, however, that dark and more greyish heads are found in the same regions, as, for example, on the Sepik River.

Specimens from the Mimika River were separated from the typical form as being darker above and paler yellow, but I cannot confirm this difference. As there is no "green tinge" on the vent in typical G. chrysogaster, I cannot see how it ean be absent in "guineensis," as Mathews ealled his supposed new form ; the name "guineensis" is absurd, as Guinea is part of West Africa.]

\section{Gerygone magnirostris ramuensis Rehw.}

Gerygone ramuensis Reichenow, Orn. Monatsber. v, p. 26 (1897-Ramu, Mandated Territory, N.E. New Guinea).

3 ô, 3 ㅇ Ifaar, Sentani Lake, second half of September and beginning of October 1928. " "Iris red-brown. Bill black. Feet dark grey."

Weight $7-8 \mathrm{~g}$.

I prefer to call this form ramuensis, as it agrees entirely with the latter, of which I have many specimens to compare (among them one of the co-types), from East and S.E. Papua. Stresemann calls these birds affinis Meyer, and says the type locality of that name is Jobi. I have before me, through the kindness of Dr. Meise, the type and co-types of Meyer, from Jobi and Passim. Unfortunately these are old and have mostly been mounted, and are therefore hardly fit for intricate comparison, but it seems to me that the specimens from Jobi approach ours from Kapaur, which we called conspicillata, and that the Passim ones are partially ramuensis. Fresh material from Jobi and Passim may very likely prove that ramuensis and affinis are the same, but at present this is doubtful.

\section{Gerygone ruficollis ruficollis Salvad.}

Gerygone? ruficollis Salvadori, Ann. Mus. Civ. Genova, vii, p. 959 (1875-Hatam, Arfak Mts.).

of, about $1,000 \mathrm{~m}$., in the mountains near Siwi, 17.v.1928. "Iris light red-brown, bill and feet black."

Wing $52.5 \mathrm{~mm}$.

Weight $6 \mathrm{~g}$.

I think that this specimen is G. ruficollis. Through the kindness of Dr. Gestro I have the type of $G$. ruficollis (the only specimen I know of) before me. It is of course true that there is a (somewhat indistinct) rufous loral line and that the throat is rufescent, as described, but this rufescent colour is pale, and, though the Siwi example has the throat white, I think it must be the same, and 
there is a rufescent patch on the sides of the neck. The tail is incomplete and on the outer rectrix is also a white spot on the outer web, in the type only on the inner web. Another subspecies seems to inhabit N.E. New Guinea.

\section{Gerygone neglecta virescens (Blyth).}

" Sylvia virescens S. Müll." Blyth, Ibis, 1870, p. 169 ("New Guinea." The specimen in the Leyden Museum, which Salomon Müller had called "Sylvia virescens," was from Lobo Bay !). Cf. Finsch, Notes Leyden Museum, xx, p. 135, 1898.-Hartert, Nov. Zool. 1920, p. 493. Gerygone neglecta dohertyi Rothschild \& Hartert, Nov. Zool. x, p. 473 (1903-Kapaur).

1 ô Siwi, 18.v.1928. "Iris dark grey. Bill (upper) black. Feet light grey-brown." Testes small.

Weight $7 \cdot 75 \mathrm{~g}$.

This form, of which we had a series from Kapaur, does not seem to have been found before in the Arfak Peninsula. The wing measures only $51 \mathrm{~mm}$., which agrees with our Kapaur females, while the males have longer wings! (Possibly this bird from Siwi is a $q$, label changed by native ?)

\section{Gerygone (Eugerygone) rubra (Sharpe).}

Pseudogerygone rubra Sharpe, Notes Leyden Mus. i, p. 30 (1879-Arfak Mts.); Cat. B. Brit. Mus. iv, p. 225.

2 ô ad. Kofo (Anggi gidji), Arfak Mountains, 12., 15.vi.1928. "Iris dark brown, bill black, feet yellowish brown."

ô juv. mountains near Ditschi, 31.v.1928.

q, label lost, probably Kofo.

This red-backed species is very rare in collections. Lord Rothschild and I recorded specimens from S.E. New Guinea in Nov. ZooL. 1903, pp. 474, 475. On the 6th or 7th primary begins a white bar across the wing, formed by white spots on the outer webs, while on the underside of the wing is a wider bar of whitish buff on the inner remiges. Wings $\hat{0} 58-62.5 \mathrm{~mm}$.

Weight $8 \mathrm{~g}$.

The younger male has the upperside not pure crimson, but crimson with a yellowish wash.

The female has hitherto remained undescribed. What Rothschild and I described, Nov. ZooL. 1903, p. 475, is not the female! The skin without a label is obviously adult and agrees in every way with the male, except that the upperside is brown with a rufous tinge. The white markings on wings and tail are as in the male. Wing $57.5 \mathrm{~mm}$.

The tail is longer than in other Papuan Gerygone (and Pseudogerygone), and this may for genus-splitters be an excuse for the genus Eugerygone.

\section{Phylloscopus trivirgatus poliocephalus (Salvad.).}

Gerygone? poliocephala Salvadori, Ann. Mus. Civ. Genova, vii, p. 960 (1875-Arfak).

Eight skins from Siwi and four from Ditschi in the Arfak region obviously belong to this rare form. "Iris dark greyish brown or dark greenish grey. Bill black. Feet dark grey (in adults)."

Wings ô 56-57, 우 52-53.

Weights oิ $8 \cdot 5$, ㅇ $9 \cdot 5 \mathrm{~g}$. 
The yellow line across the wings, formed by the tips to the greater wingcoverts, is sometimes indistinct, generally quite visible.

The greyish dusky crown is, especially in females, often quite brownish to olive-brown; in an apparently younger bird greenish brown, and the throat yellow.

\section{Phylloscopus trivirgatus cyclopum subsp. nov.}

Very near to $P h$. trivirg. giulianettii, but upperside a little brighter, more yellowish, the top of the head (the sides, not the yellowish median line) less blackish, more greenish, sides of head less yellowish, more greyish, sides of body, under wings, cleaner yellow. Wings apparently a little shorter : of 57, ㅇ 53, $54 \mathrm{~mm}$. " "Iris grey-brown, once brown-grey, bill blackish (lower however pale !), feet grey."

Type + Cyclops Mountains, 24.viii.1928.

Weight of 8.5 , $q 8$, and $9.5 \mathrm{~g}$.

Only three skins, Cyclops Mountains, 12.ix and 24. viii.1928.

I am obliged to Dr. Ernst Mayr, who called my attention to this quite distinct subspecies.

(The species was heard in the Wandammen Mountains, but no specimens could be obtained.-Ernst Mayr.)

\section{Microeca griseiceps occidentalis R. \& H.}

Microeca griseiceps occidentalis Rothschild \& Hartert, Nov. Zool. x, p. 471 (1903-“"Warmendi," Arfak).

3 ํํำ Siwi, 3 ô Ditschi. " Iris dark, bill underneath yellow, above blackish, feet orange yellow." Wing ô 75 , ㅇ $71,74 \mathrm{~mm}$.

Weight of 12 , 우 $12,12 \cdot 5,13 \cdot 5 \mathrm{~g}$.

Differs from $M$. griseiceps griseiceps of S.E. New Guinea in having the crown more olive-brown, the back of a slightly darker green, the whitish colour of the throat generally more extended, and larger size, wing in $M . g$. griseiceps o $68-69$, o $66 \mathrm{~mm}$. The latter we had also from the Hydrographer Mountains. Young birds are rufous, spotted with whitish tips !

Another subspecies of $M$. griseiceps, and in fact hardly separable, is " Kempiella "kempi Mathews. It is only a little browner on the head and darker on the back, and perhaps smaller. There are (in Europe) only three specimens, one good male and two bad ones, two from Cape York, one from Claudie River, North Queensland. When Mathews described it (Austral Avian Rec. ii, p. 12, 1913), he compared it with Poeciliodryas capito, being ignorant of the existence of Microeca griseiceps; the form must therefore be called Microeca griseiceps kempi. It adds another Papuan form to the fauna of the Cape York Peninsula.

\section{Microeca flavovirescens Gray.}

Microeca flavovirescens Gray, Proc. Zool. Soc. London, 1858, p. 178 (Aru Islands).

ô우 Hollandia, August and October 1928.

One female had an egg almost ready for laying on $9 . x$.

Weight $14 \cdot 5-15 \mathrm{~g}$. 


\section{Microeca papuana Mey.}

Microeca papuana Meyer, Sitzungsb. Ges. Isis, 1875, p. 74 (Arfak).

$\widehat{o}$ Kofo (Anggi gidji), 11.vi. 1928.

$2 \hat{o}, 1$ \& Lehuma, June 1928.

ㅇ juv. mountains near Ditschi, 9.vi.1928.

우 Wondiwoi Mountains, Wandammen Peninsula, 10.vii.1928.

"Iris dark brown. Bill, upper and under, black. Feet orange yellow."

Weight $12-14 \cdot 5 \mathrm{~g}$.

Microeca hemixantha Scl. 1883 from Tenimber is very much like $M$. papuana and might be looked upon as a subspecies, but the under mandible is pale ("colour-less "' as Kühn puts it on a label) and the feet are black !

\section{Poecilodryas cyanus cyanus (Salvad.).}

Myiolestes ? cyanus Salvadori, Ann. Mus. Civ. Genova, vii, p. 394 (1875-Hatam, Arfak Mts.).

$1 \hat{\jmath}$ mountains near Siwi.

$1 \hat{\jmath}, 4$ o mountains above Ditschi.

The sexes are alike in colour, but males larger.

Wings of $86,86 \cdot 5$, ㅇ $82-84 \cdot 5 \mathrm{~mm}$.

Weight ô $24,24 \cdot 5$, ㅇ $20 \cdot 5,22 \cdot 5,22 \cdot 5 \mathrm{~g}$.

\section{Poecilodryas cyanus subcyaneus De Vis.}

Poecilodryas subcyanea De Vis, Ibis, 1897, p. 377 (S.E. New Guinea). (Cf. Nov. Zool. x, p. 470. 1903 , for synonyms.)

3 ธิ, 5 우 Wondiwoi Mountains, Wandammen Peninsula, July.

10 oิ, 16 ㅇ Cyclops Mountains, September.

Wings of $94-101$, $+83-88$, sometimes 90 and $93 \mathrm{~mm}$., if the latter are correctly sexed.

Weight $\widehat{0} 27 \cdot 5-34$, 우 $20 \cdot 5-28 \mathrm{~g}$.

In colour like $P$. cyanus cyanus, but a little darker and more bluish.

It is interesting that the Wandammen specimens agree in this ease with the eastern form ; the fauna of Wandammen is a mixed one, but in the majority of cases the birds are the same as in the Arfak peninsula.

Sexual organs very large in September.

\section{Poecilodryas leucops melanogenys Mey.}

Poecilodryas melanogenys A. B. Meyer, Abh. \& Ber. Mus. Dresden, 1892-93, Art. 3, p. 12 (Sattelberg). Poecilodryas salvadorii Madarász, Orn. Monatsber. viii, p. 1 (1900-Sattelberg).

Poecilodryas leucops nigriceps Neumann, Verh. Orn. Ges. Bayern, xv, p. 237 (1922-Hunstein Range).

Twenty-eight from the Cyclops Mountains. A quite young bird shot 27. viii. 1928 in fluffy down plumage is dark dull chestnut-brown with paler shaftlines, one from 21. viii. 1928 retains still juvenile feathers on back and underside.

Weight $14 \cdot 5-19 \mathrm{~g}$.

I do not think that nigriceps is separable.

\section{Poecilodryas leucops leucops (Salvad.).}

Leucophantes leucops Salvadori, Ann. Mus. Civ. Genova, vii, p. 921 (1875-Arfak Mts.).

A series from Siwi, above Ditschi, and Ninei. Wing ơ 75-81 mm. Weight 15-18 g. A young bird from Ditschi, 8.vi., is like the one from 21.viii. of melanogenys, but has not yet much white on the forehead, 
127. Poecilodryas leucops mayri subsp. nov.

Almost exactly like P. l. leucops, but no black line from eye to base of bill ! There is also generally more greenish wash on nape and hind-neck, the bill is generally slightly larger and wings $79-82 \mathrm{~mm}$.

Type: ô ad. Wondiwoi, 14.vii.1928. No. 1526 Dr. Ernst Mayr coll.

This form inhabits Wondiwoi, Wandammen Peninsula. It is very near to $P$. $l$. nigroorbitalis, but slightly longer winged, the white on the throat a little less extended, the crown and nape less blackish. P. $l$. nigroorbitalis is known from the Snow Mountains.

\section{Poecilodryas cryptoleucus spec. nov.}

Differs from Poecilodryas cyanus cyanus and subcyaneus in having a white patch at the base of the inner primaries, the head is not so blackish, more greyish, and therefore less in contrast to the back, the back less blue, more sooty grey, the underside pale grey, almost without any blue in it. "Iris dark brown. Bill and feet black." Wings ô $82-88$, 우 $78.5 \mathrm{~mm}$.

Weight $\delta$ 18, 19, $20 \mathrm{~g}$.

Type: ô ad. Lehuma, 4.vi.1928. No. 993 Ernst Mayr coll.

This species, though somewhat near to $P$. cyanus, is, as described, quite distinct.

We had it from the mountains near Ditschi and Lehuma, four specimens in all, also an old one from Hatam, collected by Beccari.

Salvadori, in his immortal Orn. Pap. ii, p. 89, mentions the white patch at the base of the remiges, visible from the underside, in the diagnosis of $P$. cyanus. This mistake was caused by two specimens which he had of Poecilodryas cryptoleucus, which he describes and of which he said they were perhaps not quite adult. In the blue specimens (cyanus) there is no such white patch, or only a paler shade.

These two species occur together, as do Parus palustris and atricapillus, Certhia familiaris and brachydactyla and others in Europe.

\section{Poecilodryas brachyura brachyura (Scl.).}

Leucophantes brachyurus Sclater, Proc. Zool. Soc. London, 1873, pp. 691, 692, pl. liii ("Hatam, Arfak Mts.," but this is an error, as they came from Andai on the coast. Cf. Salvadori, Orn. Pap. ii, p. 87).

1 ô above Wasior, Wandammen Peninsula, 25.vii.1928. "Iris dark brown, bill black, feet pale flesh-colour." Wing $89 \mathrm{~mm}$.

Weight $25 \mathrm{~g}$.

\section{Poecilodryas brachyura dumasi Grant.}

Poecilodryas brachyura dumasi Ogilvie-Grant, Ibis Suppl. 1915, p. 163 ("Northern New Guinea," Dumas coll.).

Upperside black like the head instead of dark grey. See also Stresemann, Sepik-Vögel, p. 88.

2 oิ Hollandia, 3 ô ad., 3 우 ad., 1 ơ juv. Cyclops Mountains.

The young bird is in moult, on the nape, back and underside some dark chestnut feathers of the first plumage are retained.

Weight $22-27 \cdot 5 \mathrm{~g}$.

The Jobi form I do not know. 


\section{Poecilodryas hypoleucus hypoleucus (Gray).}

Petroica hypoleuca G. R. Gray, Proc. Zool. Soc. 1859, p. 155 (Dorey).

ơ Momi (near Wariah), on the east coast of the Berau Peninsula, 25.vi. and 1.vii. 1928.

Weight ôे $19 \cdot 5$, ㅇ $17 \mathrm{~g}$.

The female is brown above, the male may be called black, though the black is duller than in specimens from Hollandia and Ifaar.

This species is somewhat difficult to divide into subspecies. In all descriptions (Salvadori, Sharpe, Gray) the upperside is described as brown or brownish black. This seems to apply to birds from Arfak, Kapaur, Misol and Waigiu, though the latter may still differ in other respects. On the other hand, our specimens from Hollandia and Ifaar are pure black"above, and the white alar speculum is wider than in most western birds. There are nevertheless some specimens from S.E. New Guinea and the Utakwa and Setekwa Rivers which are not so black and agree better with the Arfak ones - the size of the white alar speculum differs also. Of the Utakwa examples Grant (Ibis, 1915, Suppl. p. 164) has already mentioned this variability. The white line above the lores varies in width and length and is not a subspecific criterion. The browner birds before me are females, but other females are as black as males.

\section{Poecilodryas hypoleucus hermani Mad.}

Poecilodryas hermani Madarász, Bull. B.O. Club, iii, p. xlvii (1894 -Finisterre Mts.).

2 ô Hollandia, 13.x., 2 ô Ifaar, 25.ix. 1928.

Weight 19, 19.5, 20, $21 \mathrm{~g}$.

133. Poecilodryas albonatatus albonatatus (Salvad.).

Megalestes albonotatus Salvadori, Ann. Mus. Civ. Gen. vii, p. 770 (1875-Arfak).

1 ô ad. Arfak Mountains, 2,000 m., 18. viii.1928. "Iris brownish black.

Bill and feet black." Mayer. Coll. by F. Shaw Mayer.

ô ad. Siwi. No. 127. Coll. by Ernst Mayr. Only a " tag," no real label.

These two specimens are the topotypical albonotatus, only known from Arfak. Wings 113, $114 \mathrm{~mm}$.

We had formerly only two very bad skins, therefore we united with albonotatus the birds from S.E. New Guinea, which, however, are quite different. I separate this latter form as

\section{Poecilodryas albonotatus correctus subsp. nov.}

Upperside paler grey, especially on the head. The black of the throat and foreneck, which in $P$. a. albonotatus reaches to the centre of the breast, only just surpasses the throat. The white on the abdomen is pure and conspicuous.

Wings ô 103, 104, 104.5, 105, 106, 106, 106, 107, 108, 우100, 101, 102, $102 \mathrm{~mm}$.

Type: ô, Mount Cameron, Owen Stanley Range, 10.viii.1896. A. S. Anthony coll.

\section{Poecilodryas bimaculatus bimaculatus (Salvad.).}

Myiolestes ? bimaculatus Salvadori, Ann. Mus. Civ. Genova, vi, p. 84 (1874-Putat, Arfak Peninsula).

9 ડึำ ad., 1 juv., Siwi, April and May.

Weight $21 \cdot 75-30 \mathrm{~g}$.

Judging from the young specimen and another of $P$. bimac. vicaria from S.E. New Guinea, the young are duller, browner, but not spotted, except with brown terminal patches to the wing-coverts. 
135. Pachycephalopsis hattamensis hattamensis Mey.

Pachycephala hattamensis A. B. Meyer, Sitzungsber. k. Akad. Wiss. lxix, p. 391 (1874 “ "Hattam" in the Arfak Mts.).

16 of from the mountains near Siwi, 1 mountains near Ditschi, 1 Ninei, 1 Lehuma. "Iris brown and pale brown, bill black, feet pale grey-reddish."

Weight 34-39, once $41 \mathrm{~g}$.

Wings ô 106, 103, 98, 우 92, 95, 94, 94, 90, 91, 94, 95, 95, 93.5 mm., also two $97,98 \mathrm{~mm}$., which may be males.

The short tail removes this species from Pachycephala.

136. Pachycephalopsis hattamensis ernesti subsp. nov.

This interesting new subspecies differs from $P$. hattamensis hattamensis as follows: The white patch on the chin and upper throat is less extended and separated from the olive-green breast by an ashy grey patch; the breast is darker, olive-green, and there is less yellow on the abdomen, the under tailcoverts are pale greenish yellow instead of light rusty. Iris in two specimens " whitish," in one ochre. Wings ㅇ 92, 93, $94 \mathrm{~mm}$.

Weight $33,35,35 \mathrm{~g}$.

Type: 우 Wondiwoi, 17.vii.1928. No. 1564 Ernst Mayr coll.

This form is very interesting, because of the existence of a form almost exactly like $P$. $h$. hattamensis on the Snow Mountain range.

It is so distinct that it was already recognized as a new subspecies by the collector in the field and marked as new subspecies on one of the labels. I gave it the collector's Christian name, as using his family name would easily have caused confusion with the Pachycephala named after A. B. Meyer.

137. Heteromyias albispecularis albispecularis (Salvad.).

Pachycephala albispecularis Salvadori, Ann. Mus. Civ. Genova, vii, p. 931 (the article is dated 31.xii.1875, so it must have priority over the name cinereifrons-Arfak Mts.).

6 1 우 Lehuma, Arfak Mountains, 1 mountains near Siwi, 2 mountains near Ditschi, 2 Dohunsehik in the Issim Valley.

" Iris dark brown, bill blackish, feet whitish, to pinkish white."

Weight $28-37 \cdot 5 \mathrm{~g}$.

I agree with Stresemann, that $H$, armiti from S.E. New Guinea should be looked upon as a subspecies of albispecularis, though the pure white instead of grey post-superciliary stripe, black lores, auricular patch and crown (instead of grey), and whiter underside give it a rather different appearance, but equally $H$. cinereifrons is a subspecies of albispecularis, differing in the paler grey crown, more rusty back and upper tail-coverts, dark rusty ear-coverts, rusty sides of body, belly and under tail-coverts. "Poecilodryas? cinereifrons" Ramsay is described in the Proc. Zool. Soc. London "1875," but according to Mathews was not published till April 1876.

But there are still more subspecies, and we must accept the following forms :

Heteromyias albispecularis albispecularis, Arfak Mountains.

Heteromyias albispecularis armiti, S.E. New Guinea.

Heteromyias albispecularis rothschildi subsp. nov., Snow Mountains.

Heteromyias albispecularis subsp. ?, Weyland Mountains.

Heteromyias albispecularis subsp. ?, Schraderberg.

Heteromyias albispecularis cinereifrons, North Queensland.

$H$. a. albispecularis and armiti have been shortly characterized above. 
H. a. rothschildi from Mt. Goliath ( $c f$. Nov. ZooL. xx, p. 497, 1913) differs from armiti in having the chin-spot not slate-colour but dull black, the same colour as the head. Wings males : $97 \cdot 5,96 \cdot 5$, females : $91,92,91,92 \mathrm{~mm}$.

Type: ㅇ ad. Mount Goliath, 17.ii.1911. No. 5412 A. S. Meek coll.

The wings of $H$. a. armiti are ot 98, 100, 101, 101, 102, ㅇ 89-94 mm.

$H$. albispecularis subsp. from the Weyland Mountains is probably different again, as our only specimen has the back darker and seems to have a grey band across the breast.

H. albispecularis subsp. from the Schraderberg may also be different again, as Stresemann said his only specimen had a much paler buff vent and abdomen.

Another point is of great interest : While the whole bill is black or blackish in both sexes in $H$. a. albispecularis, it is black or blackish with a white or whitish tip in males of H. a. armiti and rothschildi, quite black in females, while in $H$. $a$. cinereifrons it seems to have a yellow tip in both sexes!

The systematic position of Heteromyias is very interesting. The young bird is chestnut-red, like so many young Pachycephala!

\section{Monachella mülleriana (Schleg.).}

Muscicapa Mülleriana Schlegel, Ned. Tijdschr. Dierk. iv, p. 40 (1871-North Peninsula of New Guinea).

One unsexed, camp above Momi, 125 m., 16.iv.1928.

\section{Machaerirhynchus nigripectus nigripectus (Schleg.).}

Macheirhynchus nigripectus Schlegel, Ned. Tijdschr. Dierk. iv, p. 43 (1871-Arfak Mts.).

ô ad., ㅇ ad. Lehuma 8.vi.

$\widehat{o}$ ad., + ad., ô juv. Kofo (Anggi gidji), 11.vi.

Wings ô $58-60$, ㅇ $62-64 \mathrm{~mm}$.

Weight 10-12g.

M. nigripectus saturatus $\mathrm{R}$. \& H. is a very distinct subspecies, larger and deeper yellow, o nearly black above.

M. nigripectus harterti van Oort seems to be only distinguishable in the female!

\section{Machaerirhynchus flaviventer albifrons Gray.}

Machaerirhynchus albifrons G. R. Gray, Proc. Zool. Soc. London, 1861, p. 429, pl. 43, fig. 1 (Waigiu and Misol).

$3 \widehat{o}$ ad., Siwi, Arfak Mountains, $1 \hat{\delta}$ Hollandia, $\hat{\jmath}+\underline{t}$ (with large egg in oviduct) Cyclops Mountains ô Ifaar.

Weight 1 ơ 11,1 우 $10 \cdot 5 \mathrm{~g}$.

141. Peltops blainvillii blainvillii (Less. et Garn.).

Eurylamus blainvillii Lesson et Garnot, Férussac's Bull. Sc. Nat. et Géologie, xi, p. 302 (1827Dorey, formerly called Doréri).

6 ํㅜํ Hollandia, August. 우 Wasior, Wandammen.

This is the form first described, which has a larger bill and shorter wing and tail than the mountain subspecies, appropriately called montanus by Stresemann. The wings of these specimens measure : of $98,98 \cdot 5,98,99$, "우" 97 , $99 \mathrm{~mm}$.

Weight $\jmath^{*}+{ }^{2} 28-29 \mathrm{~g}$. 


\section{Peltops blainvillii montanus Stres.}

Peltops blainvillii montanus Stresemann, Anzeiger Orn. Ges. Bayern, No. 5, p. 35 (1921-Hunsteinspitze on the Upper Sepik).

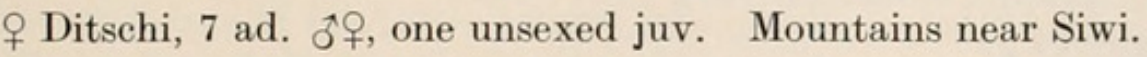

As Stresemann described: Bill conspicuously smaller, specially shorter, wings and tail longer, white patch on back larger. The white patch on back, however, varies in extent, and its larger size is sometimes obseured in bad skins. Wings ô 112, ㅇ 110, 110, 108, 114, cr. 107, 107, $111 \mathrm{~mm}$.

Weight 29-35 g.

The existence of a smaller and larger form was already recognized by De Vis, who in 1894 (Report on New Guinea for 1893, p. 2) named the small form "from the sea-level " Peltops minor. The specimens he had were evidently partially young. Stresemann distinguished the two forms as species, but they are the most typical subspecies, montanus being the mountain form of blainvillii blainvillii. Moreover, there are, specially from the Kumusi River, at least in size, intermediates, whether just varieties, or from intermediate altitudes (?) or hybrids, one cannot at present say. Stresemann mentions already a wing of the small race of 103 , one of the big form with $105 \mathrm{~mm}$., which is not much of a difference. We have examples from Stephansort with wing 107, Kumusi River 105, Upper Aroa River $108 \mathrm{~mm}$. (montanus), and specimens from Kumusi and Milne Bay have small, though not very stumpy, bills, those from Kumusi having wings of 96 (ㅇ) to $106 \mathrm{~mm}$. (ठ), the bills being also somewhat variable. The mountain form (montanus) is common in S.E. New Guinea, on the Hydrographer, Owen Stanley Mountains, Upper Aroa, Upper Mambare River, etc.

The full juvenile garb is not yet known. The white patch on the back is absent, while probably all the head and neck are white, and there are white tips to the greater wing-coverts.

\section{Chenorhamphus grayi (Wall.).}

Todopsis grayi Wallace, Proc. Zool. Soc. London, 1862, p. 166 (Sorong, Arfak Peninsula).

1 ㅇ Siwi, 1 \& Cyclops Mountains, 700 m., 20. viii. 1928.

"Iris brown. Bill black. Feet brownish earth-colour."

In the male the crown is dull greyish blue, the middle of the abdomen like the rest of the underside pale blue, brightest towards the belly.-In the female the crown is dull black, between the crown and the black ear-coverts and stripe behind the eye a pale blue line. Middle of abdomen white, under tail-coverts cream-colour. Wings ô $63,+$ ㅇ $58,59,62 \mathrm{~mm}$.

Weight +13 and $16 \mathrm{~g}$.

\section{Clytomyias insignis insignis Sharpe.}

Clytomyias insignis Sharpe, Notes Leyden Mus. i, no. 10, p. 30 (1878-Tjobonda, Arfak Mts.).

ํㅜㅇ Mount Mundi near Ninei, Arfak Mountains, 1,800 m., 27.v.1928.

Weight not stated.

The differences between $C$. $i$. insignis and $C$. $i$. oorti (S.E. New Guinea) are correctly described Nov. ZooL. xiv, p. 460, 1907. There is no difference in colour between the sexes if the two specimens from Mount Mundi are correctly sexed: $\sigma^{\wedge}$ wing 55 , ㅇ $58.5 \mathrm{~mm}$. 
145. Todopsis cyanocephalus cyanocephalus (Quoy et Gaimard).

Todus cyanocephalus Quoy et Gaimard, Voy. Astrolabe, i, p. 227, pl. 5, fig. 4 (1830-Dorey).

ô우 Siwi, 우 Momi, 오 Siwi (No. 769), 21.v. 1928.

ô ad. weight $14 \mathrm{~g}$.

146. Todopsis cyanocephalus dohertyi R. \& H.

Todopsis cyanocephalus dohertyi Rothschild \& Hartert, Nov. Zool. x, p. 477 (1903-Takar on the north coast).

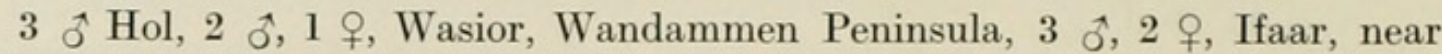
Lake Sentani.

Weight ô 13,14 , ㅇ $10 \cdot 5,12 \mathrm{~g}$.

We described this subspecies on account of the deeper, more chestnut, upperside. In Nov. Zool. xx, p. 499, we said: "Possibly T. c. dohertyi from Takar will not be tenable, the dark colour of the back perhaps being due to dampness of the skins while drying." We find now, however, that the Wasior and Ifaar birds, which were not exposed to dampness, are as dark as the Takar ones, being darker than the Arfak females. I must therefore, for the time being, recognize dohertyi, though it is closely allied and only discernible in the female. See also Nov. Zool. xxvii, 1920, p. 457.

\section{Todopsis wallacii Gray.}

Todopsis wallacii G. R. Gray, Proc. Zool. Soc. London, 1861, pp. 429, 434, pl. 43, fig. 2 (Mysol).

5 ơำ Siwi, Arfak Mountains.

Weight 8 and $8.5 \mathrm{~g}$.

\section{Monarcha frater frater Scl.}

Monarcha frater Sclater, Proc. Zool. Soc. London, 1873, p. 691 (Hatam, Arfak Mts.).

12 우오 Siwi, 1 우 Ditschi.

Weight 18 (ㅇ) to $23 \mathrm{~g}$.

149. Monarcha guttula (Garnot).

Muscicapa guttula Garnot, Voy. Coqu., Zool. i, 2, p. 591, pl. xvi, fig. 2 (1828-Dorey, Arfak).

5 ô Hol and Hollandia, 1 \& Cyclops Mountains.

Weight $16-17 \cdot 5 \mathrm{~g}$.

150. Monarcha alecto chalybeocephalus (Garnot).

Muscicapa chalybeocephalus Garnot, Voy. Coquille, Zool. Atlas, pl. 15, fig. 1 ( $)$ (1828-New Ireland).

đ우 series from Ifaar, Hol, Momi, Wasior (Wandammen) and (1) Manokwari.

We have not dared to separate the New Guinea birds from New Ireland ones. As it happens, our New Ireland female specimens are rather light. It is possible, but not probable, that the New Guinea females are generally a little darker on the upperside, but females from Feni Island appear to be darker again.

Mathews, Bull. B.O. Club, xlviii, p. 93 (1928), named three supposed new subspecies of Monarcha alecto:

"Piezorhynchus alecto woodlarkensis," which is the same as lucida (but was compared with alecto only !) ; 
"Piezorhynchus alecto longirostris" from Timorlaut, which is a tenable subspecies, and

"Piezorhynchus alecto novae-guineensis," Mimika River ㅇ!

The diagnosis of the latter is perfectly useless, as it is only compared with the different alecto $q$, but not with chalybeocephalus!! If the New Guinea form should be separated, the name of Mathews must be accepted, though he did not grasp its nearest relationship!

\section{Monarcha axillaris axillaris Salvad.}

Monarcha axillaris Salvadori, Ann. Mus. Civ. Genova, vii, p. 921 (1875-Arfak).

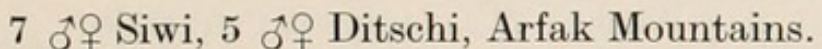

ơ우 Wondiwoi, Wandammen Peninsula, July 1928.

"Iris brown. Bill whitish blue-grey. Feet blackish or blackish grey."

The two Wondiwoi specimens may belong to another form: the male has white spots on the sides of the breast and on the abdomen, the female about as much white as the males from Arfak.

Specimens from the Lordberg (Sepik) are like Arfak ones.

Adult females are very much like the males, but less glossy black on head and throat, the white patches on the sides of the breast more restricted. Wings o $79-83 \mathrm{~mm}$. Young birds are greyish.

\section{[Monarcha axillaris fallax (Rams.).}

Rhipidura fallax Ramsay, Proc. Zool. Soc. London, 1884, p. 580 (Astrolabe Range, S.E. New Guinea. Piezorhynchus reichenowi Madarász, Orn. Monatsber. viii, 1900, p. 2 (Sattelberg).

There is no doubt, as pointed out long ago by Grant, that Rhipidura fallax of Ramsay is not a Rhipidura, but a form of Monarcha axillaris. It is the form which Madaráz described as Piezorhynchus reichenowi from the Sattelberg. This form is much smaller (cf. Stresemann, Archiv f. Naturg. 89, 8tes Heft, p. 2, 1923 ) and the white patch on the sides of the breast is reduced in size, in the females still more. Young birds are slaty, there are only some small dull white tips to the slaty grey axillaries. The bill is apparently darker, it is described on labels as dark chalky blue with black tip. Wings ô 74-78 mm.

Specimens from the Aroa River, head of Mambare, Hydrographer Range, and Sattelberg (Mayr coll.) are alike.]

\section{Monarcha chrysomela melanonotus Scl.}

Monarcha melanonotus Sclater, Proc. Zool. Soc. London, 1877, p. 100 ("New Guinea "-Sclater had only Arfak specimens from New Guinea, therefore Arfak is the terra typica !).

2 ô Momi, 15.iv. and 25.vi.

Weight 16.5 and $18 \mathrm{~g}$.

The April specimen is typical of the Arfak form, but the June one is deeper, more orange, on the underside, and thus resembles $M$. chrys mela aurantiacus!

\section{Monarcha chrysomela aurantiacus Mey.}

Monarcha melanonotus aurantiacus A. B. Meyer, Abh. \& Ber. Mus. Dresden "1890-91," Art. 4, p. 9 (1892-Kafu and Stephansort).

5 oิ Hol, 1 ơ Cyclops Mountains.

Weight ô $15-17 \mathrm{~g}$.

This form is very closely allied to melanonotus, only the orange colour is deeper-one of the Momi specimens is not really distinguishable. 


\section{Monarcha rubiensis (Mey.).}

Tchitrea rubiensis A. B. Meyer, Sitzungsber. Akad. Wissensch. Wien, lxix, p. 494 (1874-Rubi).

ô Momi, 25.vi.1928.

This specimen, evidently a young male, has the lores and forehead much paler than it is in adult females. In females the colour of the abdomen varies to some extent.

\section{Arses telescophthalmus telescophthalmus (Garn.).}

Muscicapa telescophthalmus Garnot, Voy. Coquille, Zool. i, p. 593, pl. 18 (1828-Dorey).

3 ภิ, 1 ㅇ Siwi, 3 ô, 2 우 Momi, 2 oิ Wasior, Wandammen Peninsula.

" of" iris deep brown. Bare skin around eye whitish blue. Bill whitish blue-grey, lead-grey. Feet dark grey. "ㅇ" iris dark brown. Bill greenish grey, bluish grey-in a young $\widehat{o}$ in female's garb tip dark brown.

\section{Arses (telescophthalmus) insularis Mey.}

Monarcha insularis A. B. Meyer, Sitzungsber. Akad. Wien, lxix, p. 395 (1874 Jobi).

\section{3 ठิ, 2 ㅇ Hol and Hollandia, 2 ô, 1 ㅇ Cyclops Mountains.}

Synonym is evidently Arses fenicheli Madarász, Aquila, i, p. 93 (1894Bongu on Astrolabe Bay), described from one female !

It may be doubtful if it is not premature to decide if insularis should be considered to be a subspecies of telescophthalmus. The distribution of insularis is from Jobi along the north coast and its hinterland to the Astrolabe Bay, this interrupting that of two obvious subspecies of telescophthalmus.

The form from the S.E. of New Guinea with a white-bellied female and golden orange throat and chest in the male is $A$. (t.) henkei Meyer, Zeitschr. ges. Orn. iii, p. 16 (1886-Astrolabe Mountains!).

Later on Salvadori (Ann. Mus. Civ. Genova, xxix, p. 566, 1890-Rigo, on the coast, S.E. of Port Moresby) described A. orientalis with a light rufescent abdomen. In 1903 Lord Rothschild and I thought this must be variety of henkei, but it may be a geographically separable form? We have the whitebellied form (typical henkei) from Nicura, Aroa River, Brown River, the Kotoi and Oriori district of the Owen Stanley Mountains, the rufescent-bellied one (typical orientalis) from Collingwood Bay, 7 from the Hydrographer Mountains, 5 Kumusi River. Further observations must show, if these forms occur together, or if they are (as it seems) geographically represented.

In very worn plumage the back in henkei gets browner (less rufous) and a cream-coloured collar becomes conspicuous.

\section{Rhipidura leucophrys subsp.}

2 " o " Manokwari, but one has a wing of $111 \mathrm{~mm}$. which is a large measurement for a female.

ô juv. Ifaar. The young bird is glossless black with red-brown tips to the feathers, the superciliary white line is wider, cream-coloured and reaching to the nape.

It is difficult to decide about the subspecies. It was not so stupid of us and Ogilvie-Grant to unite all the birds from East and North Australia with those of New Guinea and Papuan Islands. The various forms seem to differ 
only by size; as they vary a good deal, no form can be separated except when a good series is available.

Mathews showed that the name leucophrys Latham is older than tricolor! This was important for the nomenclature, but in 1928 the same author made a difficulty for his brother ornithologists by giving a name (amboynensis) to the birds from the Moluccas, but he compared them only with the birds from Aru, leaving one in ignorance about those from New Guinea, New Ireland (terra typica of melaleuca!), etc., etc.

\section{Rhipidura threnothorax S. Müll.}

Rhipidura threnothorax S. Müller, Verh. Land-en Volkenk. p. 185 (1844-Lobo, which is at Triton Bay).

Setosura threnothorax novae-guineensis Mathews, Bull. B.O. Club, xlviii, p. 92 (1928-Mimika River).

4 ô, 3 ㅇ Siwi, Arfak Mountains, May 1928.

The males are darker, more blackish, on the abdomen, wings of $85,82.5$, 83,84 , ㅇ $77,79,80 \mathrm{~mm}$.

Weight $18 \cdot 5-21 \mathrm{~g}$.

Mathews described the Mimika River bird as having the under surface distinctly darker and the white spots on the chest smaller. The darker underside is characteristic of males, the white spots vary considerably in the same localities !

From the Kumusi River we have four skins and one from Boboli, China Straits, in the utmost east of New Guinea, which all have the underside pale like females from Western New Guinea ; though three are sexed "male," it looks as if they were females, judging by the colour of the abdomen, but their wings are all three over $80 \mathrm{~mm}$. A greater series might show that there is a race with lighter abdomen in S.E. New Guinea? In both sexes the upper mandible is black, but the lower whitish !

\section{Rhipidura rufiventris gularis Müll.}

Rhipidura gularis S. Müller, Verh. Land-en Volkenkunde, p. 185 (1844 - Lobo, Utanata).

Siwi, Wasior (Wandammen), Hol, Hollandia and Ifaar.

Weight 13-15 g.

\section{Rhipidura hyperythra mülleri Mey.}

Rhipidura Mülleri A. B. Meyer, Sitzungsber. k. Akad. Wien, lxix, p. 502 (1874-New name for Rhip. rufiventris Müller, nec Vieillot! Terra typica therefore Lobo).

4 ô Siwi, 1 ơ Ninei, 6 ơ Cyclops Mountains.

Weight $10 \cdot 5-13 \cdot 75 \mathrm{~g}$.

This form, the continental representative of the Aru Islands Rhip. hyperythra hyperythra Gray, is hardly separable from the latter. The accepted difference is that the Aru form is to have a smaller, the New Guinea bird a larger, white chin-spot. This seems to be the case, but many of our Aru birds, as well as of the Siwi and Cyclops Mountain one, have the throat badly prepared. I prefer to keep the two forms separate, but it is not a crime to unite them. On the other hand, Ogilvie-Grant is quite wrong, when (Ibis, 1915, Suppl. p. 154) he says that the variability in the size of the white ends to the rectrices is so great, that they may obscure the difference. The fact is, that the white ends to the rectrices are considerably larger in the S.E. birds, which must be called Rhip. 
hyper. castaneothorax Ramsay, Rhip. manayoensis De Vis, Report New Guinea, 1894 , p. 2 (evidently from Mount Manaeao), being a synonym.

A young bird of the latter form, from the Hydrographer Range (where the species is common), has the whole throat dirty white, rest of underside paler and duller than in the adults, and rufous tips to smaller and larger upper wingcoverts.

In all these subspecies the upper bill is black, the lower whitish.

\section{Rhipidura rufidorsa Mey.}

Rhipidura rufidorsa A. B. Meyer, Sitzungsber. k. Akad. Wiss. Wien, lxx, p. 200 (1874-Rubi, Passim, Jobi).

$2 \hat{o}, 1$ ㅇ Siwi, Arfak Mountains.

Weight of 10 and 11 , ㅇ $8.5 \mathrm{~g}$.

(Mathews has separated two supposed new subspecies in 1928. In April (Bull. B.O. Club, xlviii, p. 92) he named Rhipidura rufidorsa nova from a Mimika River specimen in the British Museum. He says the head is darker grey and the under surface more suffused with buff than in $R$. $r$. rufidorsa.

I cannot find these differences at all constant.

In July he named (Nov. ZooL. xxxiv, p. 373) Rhipidura rufidorsa kumusi from specimens in the Tring Museum from the Kumusi River in S.E. New Guinea, saying that they had a lighter, more greyish head and a lighter brick-red back and rump. This does not seem to be separable either, but the beautifully prepared Kumusi River specimens do look somewhat light. The question must remain in abeyance until we have a series of equally well-prepared examples from the typical localities.)

\section{Rhipidura brachyrhyncha Schleg.}

Rhipidura brachyrhyncha Schlegel, Ned. Tijdschr. Dierkunde, iv, p. 42 (1873-Arfak Peninsula). Rhipidura rufa Salvadori, Ann. Mus. Civ. Genova, vii, p. 923 (1875-Arfak Mts.).

Rhipidura montana Mathews, Bull. B.O. Club, xlviii, p. 92 (1928- "Mt. Albert Edward, S.E. New Guinea ").

For about half a century this species, except for the single types of $R h$. brachyrhyncha and rufa, remained unknown, and now it seems to turn up everywhere. In 1894 De Vis recorded both Rh. brachyrhyncha Schleg. and Rh. rufa Salvadori from Mount Manaeao in S.E. Papua-but Salvadori mistook Schlegel's brachyrhyncha for the female of Rh. atra, and redescribed brachyrhyncha under the name of Rh. rufa. Let us hope that one of De Vis's two species is the true brachyrhyncha. Stresemann quoted the true brachyrhyncha from the Upper Sepik River in 1923.

Mathews described a specimen in the British Museum from Mount Albert Edward as Rh. montana, mentioning as a probable ally Rh. lepida from the Pelew Islands, having no knowledge of Rh. brachyrhyncha and rufa, and their history. Of course it is possible that the S.E. form differs slightly, the type looking somewhat brighter in colour, but it is the same species.

Dr. Ernst Mayr sent one $\hat{\sigma}$ from the mountains near Ditschi, 9.vi.1928, another $\sigma^{\top}$ from Kofo (Anggi gidji), 15. vi.1928, on the label of which is marked : "Iris dark brown. Bill 'schwarzrötlich.' Feet 'graurosa.', Weight 8.5 g. Wings 68.5 and $70 \mathrm{~mm}$.

Literature: Finsch, Notes Leyden Museum, xv, 1893, p. 81. 
A specimen of the same date (15.vi.1928) from Kofo, and a 9 from Lahuma agree with the two males of Rh. brachyrhyncha, except in the tail! The latter is deep brown from above, outer edges rufescent, the tips much paler, greyish. The shafts of the two middle rectrices are black, those of the others white or whitish, thus reminding one of some New Zealand and other species. One is, as I have said, a female; the sex of the other, though the importance was known, could not be determined. Both are smaller, wings of both $63.5 \mathrm{~mm}$.

What are these birds? I am inclined to think they must be the females of Rh. brachyrhyncha. Against this theory, however, speaks the fact that this kind of sexual dimorphism is not known in the genus Rhipidura, and that Mayr collected in N.E. Papua a specimen of apparently a closely allied but different subspecies with the tale of the latter two specimens, but sexed it $\hat{o}$, and the wing is over $70 \mathrm{~mm}$.

\section{Rhipidura atra Salvad.}

Rhipidura atra Salvadori, Ann. Mus. Civ. Genova, vii, p. 922 (1875-Hatam and Mori). Deser. of s. Rhipidura cinnamomea Meyer, Zeitschr.f.ges. Orn. iii, p. 17 (1886-Owen Stanley Mts., S.E. slopes). Rhipidura brachyrhyncha (nec Schlegel !) Salvadori, Orn. Pap. ii, p. 72.

(The history of the type of brachyrhyncha Schlegel and Salvadori's error in considering a female of atra to be Schlegel's type, is clearly explained by Büttikofer, Notes Leyden Mus. xv, p. 81.)

2 ธิ, 3 q Mountains near Ditschi (Arfak Mountains).

1 ㅇ Ninei, Arfak Peninsula.

2 oิ, 2 우 Mountains Wondiwoi, Wandammen Peninsula.

7 ô, 6 ㅇ Cyclops Mountains.

Some of the females from the Cyclops Mountains shot 5.ix.1928 had very large eggs, one was shot by the side of an empty nest.

The differences suggested by Ogilvie-Grant, and quoted by Stresemann for specimens from S.E. and N.W. New Guinea, are individual. The amount of white on the under wing-coverts and axillaries is most variable in the same localities, and so is the intensity of the rufous of the females, both in N.W. females and in those from S.E. Papua. Only the Cyclops Mountains females are all six rather dark, which must be accidental.

\section{Rhipidura albolimbata albolimbata Salvad.}

Rhipidura albo-limbata Salvadori, Ann. Mus. Civ. Genova, vi, p. 312 (1874-Hatam, Arfak). Rhipidura albo-limbata lorentzi van Oort, Nova Guinea, ix, i, p. 85 (1909-Hellwig Mts.).

2 ô mountains near Ditschi, 7 $\widehat{\jmath}$ 우 Cyclops Mountains.

The closely allied $R h$. (albolimbata) auricularis De Vis, described in ignorance of the existence of albolimbata, differs only in the paler upperside and somewhat paler, greyish portions of the underside. Nevertheless, it must be separated as a subspecies, and our remark that the Mount Goliath specimens agree " perfectly "with those from the Aroa, Angabunga and Mambare Rivers is incorrect.

De Vis seems to have redescribed his auricularis as Rhip. concinna in another "Report," about a year afterwards.

Young birds have rufous tips to the secondaries, rump-feathers and scapulars, also on the underside, but we have only moulting specimens, none in full juvenile plumage. 


\section{Rhipidura leucothorax Salvad.}

Rhipidura leucothorax Salvadori, Ann. Mus. Civ. Genova, vi, p. 311 (1874-Hatam, Arfak Mts.).

Cf. Nov. Zool. 1903, p. 463.

$1 \hat{\jmath}, 2$ 우 Wasior (Wandammen), 3 ô Ifaar.

The upper bill is black, the lower mandible whitish (pale horn-colour, teste Doherty).

A small series from S.E. New Guinea has the back paler than in specimens from Arfak, Wandammen, the north coast and Setekwa River. If this difference is constant, they must be separated as

Rhipidura leucothorax episcopalis Ramsay.

(Rh. episcopalis Ramsay, Proc. Linn. Soc. N.S. Wales, ii, p. 371, 1878, from an example with uncertain locality, but probably from the south coast of New Guinea. Ramsay of course stated no differences from leucothorax of which he was in ignorance.)

\section{Malurus alboscapulatus alboscapulatus Mey.}

Malurus alboscapulatus A. B. Meyer, Sitzungsber. k. Akad. Wissensch. Wien, 1xix, p. 496 (1874Arfak Mts. about 3,500 feet).

$4 \hat{\sigma}$ ad. in black plumage, 5 apparently adult females with white underside (black sides to chest and some black feathers across the breast), 10 in moult and white underside, 2 ㅇ juv., like females, but plumage fluffier, above brown, underside creamy white, flanks buffy. All Arfak Mountains.

Weight ô $10 \cdot 5-12 \mathrm{~g}$.

This is doubtless the true alboscapulatus, in which the female remains white underneath, through life.

167. Malurus alboscapulatus aida subsp. nov.

2 ô ad. Hollandia, 12 oै, 10 \& Ifaar, on the Sentani Lakes.

Weight ô 9-11, 우 8-10 g.

In this form neither the young nor the adult females are white underneath, but black. These black females are like the males, but smaller and less glossy, the glossy blue-black edges to the feathers being entirely or almost entirely absent. The young is sooty brown all over. Cf. R. \& H., Nov. ZooL. x, 1903, p. 478. Wings ô 49-51, ㅇ 45.5-47 mm. Weights ô우 8-10.5 g. Iris brown. Many specimens in moult in September.

Type: ㅇ Ifaar, 26.ix.1928. No. 2622 Ernst Mayr coll.

[Further subspecies are :

Malurus alboscapulatus naimii Salvad. \& Alb.

In colour like $M$. alboscapulatus alboscapulatus from the Arfak Peninsula, but smaller!

Cf. Nov. Zool. 1903, p. 478, Stresemann, Sepik-Vögel, p. 9.

S.E. and N.E. New Guinea!

\section{Malurus alboscapulatus lorentzi van Oort.}

Males like those of $M$. alboscapulatus alboscapulatus, but females and young males above not so black as in the other forms, being quite brown, on the rump fawn, underside white without any black markings, flanks and under tail-coverts buff or pale fawn colour. 
Southern slopes of Snow Mountains from the Noord River (Lorentz) to the Weyland Mountains.

The different coloration of females and a number of males (which we now look upon as non-adults) has puzzled authors considerably. There have been suggestions of a non-breeding (eclipse) plumage, of dimorphism in juveniles and in females, etc. But my friend Stresemann and I have compared the wonderful series collected by Ernst Mayr, Meek and Eichhorn, and other collectors, and we have now come to the above conclusions.

Cf. Rothschild \& Hartert, Nov. ZooL. 1903, p. 478, 1913, p. 502 ; Van Oort, Nova Guinea, ix, i, p. 91, 1909 ; Stresemann, Sepik-Vögel in Archiv f. Naturg. 89, 1923, Heft 7 \& 8, pp. 8-10 ; Ogilvie-Grant, Ibis Suppl. 1915, pp. 107-110.]

\section{Cisticola exilis diminuta Math.}

Cisticola exilis diminuta Mathews, B. Australia, ix, p. 373 (May 1922 - Cape York, North Queensland.

It seems that the above is the correct name-if, as it seems, mixta Math., which has priority, is somewhat different?-for all the New Guinea specimens of $C$. exilis ; we hope soon to learn all about this in Lynes's fortheoming monograph of the genus.

5 of ad. with unstriped heads, September, 2 of with striped heads of the same date, one of the latter with fairly large testes, and three with more or less yellowish underside, which must all three be more or less juvenile, one + , the other two doubtful, but the $q$ is said to have had a large ovary-all from Ifaar.

Weight of adults $8-8 \cdot 5 \mathrm{~g}$.

\section{Megalurus timoriensis stresemanni subsp. nov.}

6 Kofo (Anggi gidji), 11. and 12.vi.1928, 5 ô (1 testes large), 1 q, but according to size also a male.

Weight of 29-32 g.

These specimens are puzzlingly near $M . t$. macrurus from S.E. New Guinea, but flanks richer buff (except one from S.E. which has equally rich sides), and the under tail-coverts with black shaft-lines, or at least the shafts black. The heads are rather dark chestnut, the tails deep chestnut-brown, the backs dark and boldly striped, the wings outside rather dark. In all these characters, however, except the striped under tail-coverts, we find single specimens from the S.E. that equal these birds from the Arfak Peninsula. Wings 72, 73, 73, 72, 75 (" " क "), $77^{11} \mathrm{~mm}$.

Type: ô Kofo, 12.vi.1928. Ernst Mayr coll. No. 1107.

From Meg. tim. mayri these birds differ in the much darker upperside, like Meg. tim. macrurus.

170. Megalurus timoriensis mayri subsp. nov.

9 ô, 7 \&, 6 ô juv. Ifaar, September and October.

Weight ô ad. 27-30, 우 ad. 23-26 g.

These specimens differ from 19 ơ +9 from S.E. New Guinea and one from the Rawlinson Mountains (Keysser coll.), 1,450 m. above the sea, in being much lighter above, the ground colour not so deep rufous, more yellowish and with a

1 This specimen moults the first primaries and it may be that the longest ones, which form the tip of the wing, are already pushed forward, previously to falling out. 
faint greyish tinge, and the edges to the secondaries equally much lighter, less rufous. Also the tail is less rufous. The females are much smaller than the males. What must be more or less juvenile birds have the crown not rufous (more or less sharply striped with dusky) but pale brown with wider and more distinct blackish stripes, the back and tail still less rufous. Quite young birds have yellow on the underside. Wings of 70-74.5, of $67-68 \mathrm{~mm}$.

The dimensions of M.t. macrurus, the S.E. Papuan subspecies, are similar ; in worn plumage the upperside of the latter fades and resembles more that of mayri.

The specimen from the Rawlinson Mountains belongs undoubtedly to the darker, more rufous S.E. race.

The oldest name of the species is $M$. timoriensis Wall, and not alisteri. The Amboina bird was described by Salvadori in 1875, evidently from females only, as the small measurements show.

It would seem that the Amboina birds are nothing but migrants from Australia; but it is not likely that such a short-winged and long-tailed bird is much of a migrant; against this stands further the fact that we have five skins that were collected in Amboina in January and March, but these January and March specimens do not differ from a number of Australian birds.

Mathews pointed out correctly that Temminck's name Malurus galactotes was inapplicable, and that it certainly was never meant for an Australian bird, but for an African Cisticola! He therefore named the common Australian form alisteri, but the names timoriensis and amboinensis are much olderwhether amboinensis is absolutely the same as the Australian form or a slightly different subspecies nesting on Amboina. The name amboinensis is also a year older than macrurus!

Type of Megalurus timoriensis mayri:

ồ Ifaar, 26.ix.1928. Ernst Mayr coll. No. 2625.

We may therefore distinguish :

\section{Megalurus timoriensis macrurus (Salvad.).}

Sphenoeacus marurus Salvadori, Ann. Mus. Civ. Genova, ix, p. 35 (1876-S.E. New Guinea).

S.E. New Guinea to Rawlinson Mountains. (The Konstantinhafen specimen-Astrolabe Bay-may belong to this form, or possibly to mayri.)

\section{Megalurus timoriensis interscapularis Scl.}

Megalurus interscapularis Sclater, Proc. Zool. Soc. London, 1880, p. 65, pl. vi.

Very similar to macrurus, but less rufescent.

New Britain and New Ireland.

\section{Megalurus timoriensis amboinensis (Salvad.).}

Sphenoeacus amboinensis Salvadori, Ann. Mus. Civ. Genova, vii, p. 988 (1875-Amboina).

Synonyms probably alisteri Mathews, dulciei Math., oweni Math., mayi Ashby, but further investigations desirable._-Amboina and apparently Northern Australia to New South Wales. If characters should be found to separate the Australian form, that must be called alisteri.

Like $M . t$. mayri but smaller! 
4. Megalurus timoriensis melvillensis Math.

Megalurus alisteri melvillensis Mathews, Austral Avian Rec. i, p. 92 (Melville Island).

More rufous, almost exactly like macrurus, but flanks more rufescent and smaller !

Two specimens from Melville Island in the Mathews collection.

Antea p. 79.

5. Megalurus timoriensis stresemanni Hart.

Differs from its nearest ally Meg. amb. macrurus from S.E. New Guinea in its striped under tail-coverts.

Arfak Peninsula, where it was discovered by Dr. Ernst Mayr.

See antea p. 79

6. Megalurus timoriensis mayri Hart.

Only known, so far, from Ifaar, Sentani Lakes.

7. Megalurus timoriensis timoriensis Wall.

Megalurus timoriensis Wallace, Proc. Zool. Soc. London, 1863, p. 489 (1864-Timor).

Seems to be larger than amboinensis !

Timor only?

8. Megalurus timoriensis inquirendus Siebers.

Megalurus macrurus inquirendus Siebers, Treubia, x, p. 403 (1928 - One specimen from East Sumba!).

Has been separated by Siebers, because it is somewhat reddish on the upperside and the head very strongly spotted. But it is a juvenile !

Sumba.

171. Crateroscelis sanfordi spec. nov.

The whole underside dull rufous brown (somewhat like raw umber of Ridgway), sometimes a little darker. Upperside blackish chocolate-colour. Sides of the head generally darker than the underside. Iris marked variously as dark brown, rust-brown, red-brown, pale red-brown, ochre. "Bill black," but the under mandible is more or less light-coloured, probably pale horn-brown. Feet reddish grey. Wings ô $64,62,63,64$, ㅇ 59 ; tail ô $37-39$; tarsus ô 29 , ㅇ 26 ; bill ơㅇ 16-17 (from base) $\mathrm{mm}$.

Weight ô 19-19.5, ㅇ $17 \cdot 5 \mathrm{~g}$.

Type: ô Wondiwoi, 14.vii.1928. No. 1521 Ernst Mayr coll.

3 ธิ, 1 ㅇ, 2 ?, all from Wondiwoi, Wandammen Peninsula, mid July 1928.

\section{Crateroscelis robusta deficiens subsp. nov.}

This form is a little deeper brown on the upperside than $C$. r. robusta, more blackish, less rufous on the upper tail-coverts and rectrices and wanting entirely the dark ashy brown pectoral band which is so well marked in males of $C$. r. robusta. Iris brown or chestnut brown.

Wings ô $65-67$, once 68 , ㅇ $61-64$, once $65 \mathrm{~mm}$.

Weight 19-22.5, once $24 \mathrm{~g}$. 
13 ôt Cyclops Mountains. Testes mostly swollen first half of September.

Type: ô ad. Cyclops Mountains, 10.ix.1928. No. 2266 Ernst Mayr coll.

\section{Crateroscelis robusta peninsularis subsp. nov.}

In colour like $C . r$. deficiens, the throat being white, the rest of the underside whitish, sides, belly and under tail-coverts dark brown, the belly about chocolatebrown. Iris males "whitish, light yellowish red, dark red," females " greybrown, brownish grey." Wings ô $60-64$, $q 55-60$ or $61 \mathrm{~mm}$.

Weight 12-16 g. Bill shorter than in deficiens.

A quite young bird, has the whole underside brown, the feathers being lighter, more whitish, towards the base.

Type : ô Lehuma, Arfak Mountains, 8.vi.1928. No. 1065 Ernst Mayr coll.

Nine more or less adult $\delta$ ơ Lehuma and mountains above Ditschi, Arfak Mountains.

The following forms of Crateroscelis robusta, the first described by Rothschild and Hartert as $C$. pectoralis in 1900 , are established.

1. Crateroscelis robusta robusta De Vis 1898. S.E. New Guinea: Upper Aroa River, Mount Cameron, 7,000 feet; Mount Knutsford, 11,000 feet; Mount Scratchley. Anthony, Meek, and Weiske coll.

2. Crateroscelis robusta albigula Rchw. 1915. Schraderberg and Huon or Kay Peninsula.

3. Crateroscelis robusta deficiens Hart. 1930. Cyclops Mountains.

4. Crateroscelis robusta peninsularis Hart. 1930. Arfak Mountains.

\section{Crateroscelis murinus (Scl.).}

Myiothera murina Bonaparte, Consp. Gen. Av. p. 18 (Nomen nudum ex Müller MS. in Leyden Mus.).

Brachypteryx murina Sclater, Journ. Linn. Soc. London, ii, p. 158 (1858-Lobo !).

6 ํㅜㅇ Siwi, 1 Hollandia, 7 Cyclops Mountains.

Iris red-brown, in one cocoa-brown.

Weight 13-16, once $17 \mathrm{~g}$.

\section{Sericornis magnirostris cantans Mayr.}

Sericornis arfakiana Salvadori, Ann. Mus. Civ. Genova, vii, p. 962 (1875-Arfak Mts.).

Sericornis magnirostris cantans Mayr, Orn. Monatsb. 1930 (Nom. nov. pro Sericornis arfakiana, nec Geryone arfakiana which is a Sericornis !).

6 ô, 10 \&, 3 juv. from Siwi, Ditschi and Lehuma, Arfak.

Weight $11-14 \mathrm{~g}$.

These birds are very puzzling. I was at first inclined to look upon them as two species, one was on head and neck more rufescent, underside darker, more rufous, and the edges of the greater upper wing-coverts dull olivaceous-rufous, another with less phaeomelanin in the plumage, the underside being more pale dirty yellowish, the throat hardly or not at all rufescent, the edges of the greater upper wing-coverts whitish or pure white and sharply defined. There are, however, intermediate specimens, in which the white edges to the wing-coverts are indicated, while the brownish colour is present underneath, and specimens with a yellowish underside lack the clear white edges to the wing-coverts. I 
cannot, therefore, think otherwise than that all the above birds are one and the same subspecies, and they can only be a subspecies of $S$. magnirostris.

This remarkable dichromatism - if my view is correct-is still more strikingly developed in the Cape York form, Sericornis minima of Gould. The males of that form have the forehead and lores blackish, the females rufous brown, and in both adults there is a wide white short streak above the lores and a white line above and below the eyes; the young of this form look almost exactly like the adults ! But there is at Cape York also a form with a rufous head all round, with the breast and abdomen suffused with rufous (while they are pale sulphuryellow in the typical minima, there are no blackish lores), and the white stripes above the lores are only indicated. The greater upper wing-coverts have distinct white spots, but not the white edges of the sharply marked males with less phaeomelanin.

If this theory should not be correct, we would have two distinct species as well in Arfak as at Cape York, in Arfak with intermediates, at Cape York not-at least we have not seen them ; in each case the brownish birds without black and white markings on the head would undoubtedly be subspecies of $S$. magnirostris, the other two would require new names, and would be subspecies of S. minima.

I have been greatly assisted in the study of these birds by Dr. Stresemann and Mr. Arthur Goodson, to whom my thanks are due.

\section{Sericornis magnirostris cyclopum subsp. nov.}

$4 \hat{\jmath} \mathfrak{\jmath}$ Cyclops Mountains, 4 $\hat{\jmath}$ 우 Wondiwoi (Wandammen).

The lores of adult males are sometimes very deep brown, almost black, there is a white line above the lores, but not so wide as in adult males of minima, and there are a few white feathers above and below the eye ; there are white edges to the great upper wing-coverts ; upperside a shade darker than in minima, almost exactly as in cantans. Underside pale yellow, sides washed with olive, throat whitish, sometimes faintly spotted, chest clouded with greyish olivaceous, sometimes distinctly spotted. In other males and females the lores are dull rufous brown as in females and there is no white above and below the eyes, and the white above the lores is more or less brownish and only indicated. The iris is " red-brown." Wings of $59-63$, ㅇ $55,57 \mathrm{~mm}$.

Type : ô ad. Cyclops Mountains, 22.viii.1928. No. 1938 Ernst Mayr coll.

Weights ô $11 \cdot 5,12 \cdot 5,12 \cdot 5,13 \cdot 5$, ㅇ $12 \cdot 5 \mathrm{~g}$.

We have also a specimen taken by J. Dumas near Humboldt Bay. Sericornis magnirostris cyclopum is very much like $S$. magnirostris beccarii from the Aru Islands, but in the latter the black and white markings are always distinct in the males, the rufous brown and white ones distinct in the females; wings ô $59,59,59$, ㅇ $52 \cdot 5,52,58 \cdot 5 \mathrm{~mm}$.

Stresemann, in his Sepik article, was the last to attempt a list of the subspecies of this group.

The Papuan subspecies would be :

Sericornis magnirostris nouhuysi Oort, Snow Mountains. Underside uniform rufous, no black and white markings on head.

S. magnirostris oorti R, \& H, Underside yellowish. S.E. New Guinea, 
S. magnirostris rufescens Stres. Like oorti but larger. Schraderberg.

S. magnirostris pontifex Stres. Underside hardly yellowish at all, almost dirty greyish. Lordberg and Hunsteinspitze.

S. magnirostris virgata (Rchw.) does not seem to differ in colour from pontifex but seems smaller; if not separable, virgata would have priority over pontifex.

S. magnirostris keysseri from the Rawlinson Mountains.

S. magnirostris cantans Mayr, Arfak Mts. (See p. 82.)

177. Sericornis perspicillata goodsoni subsp. nov.

Upperside as in S. p. perspicillata, underside often, but not always, less fulvescent, but the ear-coverts not reddish isabelline, but pale brown, the ring round the eyes (eyelids) not reddish isabelline or bright fulvous, but creamcolour with a brownish tinge. Iris dark brown, bill black, feet pale reddish grey.

Wings ô 53-55, ㅇ 51-52 mm. Weight $8,8 \cdot 5,9 \mathrm{~g}$.

5 ô, 2 juv., 3 o Lehuma, Dohunsehik in Issim Valley, and mountains near Ditschi in the Arfak Mountains, May and June.

Type: ô Lehuma, 4.vi.1928. No. 975 Ernst Mayr coll.

Named after Arthur Goodson, Tring.

The discovery of this form in Arfak is of great interest, as S. perspicillata was hitherto not known from the Arfak Peninsula.

At Lehuma, Arfak Mountains, a young Cuculide, which seems to be Cacomantis castaneiventris arfakianus Salvad., was taken from the nest of this form, No. 968 being the foster-parent.

\section{Sericornis arfakiana arfakiana Salvad.}

Sericornis arfakiana Salvadori, Ann. Mus. Civ. Genova vii, p. 960 (1876-Arfak).

Though very closely allied to $S$. arfakiana olivacea from the mountains of S.E. New Guinea, all the specimens from the Cyclops Mountains have a less pigmented underside, the throat and chest, as well as the sides, being less greyish olivaceous, the throat and ehest in $S$. a. olivacea having distinetly ashy central stripes to the feathers, which are absent in $S$. a. arfakiana.

Wings males $52-55$, females $49-52$, mostly $50 \mathrm{~mm}$.

Weight females $7 \cdot 5-8 \cdot 5$, males $8 \cdot 5-9$, once $10 \cdot 5 \mathrm{~g}$.

2 ㅇ Siwi, 1 ô, 3 ㅇ Ditschi, ô Lehuma, 7 ํํำ Wondiwoi (Wandammen), 8 ํㅜㅇㅜ Cyclops Mountains.

Iris dark brown, dark grey-brown. Bill black. Feet pale pinkish grey.

[Sericornis rufescens (Salvad.), described as Gerygone, has not been found by Dr. Mayr (cf. Orn. Monatsb. 1930).]

\section{Aethomyias spilodera spilodera (Gray).}

Entomophila ? spilodera G. R. Gray, Proc. Zool. Soc. London, 1859, p. 155 (Dorey, Arfak).

2 of, 6 ㅇ Siwi, Arfak Mountains. " Iris brown-red, red-brown, red, bill pale reddish, pale flesh-colour, feet reddish grey."

Weight $9,10,10 \cdot 5 \mathrm{~g}$. Wings ô $60,+55 \cdot 5-58$, once $60 \mathrm{~mm}$., but perhaps $\hat{\delta}$ ?

Lord Rothschild and I have (Nov. ZooL. xx, p. 501) quite correctly said 
that Snow Mountains specimens are very near Ae. spilodera guttata Sharpe from S.E. New Guinea, but possibly a new subspecies. Ogilvie-Grant ealled them "Ae. spilodera."

The British Museum specimens from the south slopes of the Snow Mountains confirm this, and the Snow Mountains form must be nominally separated. I name them in memory of Ogilvie-Grant, who-though he tried to disagree with us wherever he thought he could-has done much to further the knowledge of those parts of New Guinea :

\section{Aethomyias spilodera granti subsp. nov.}

This subspecies differs from its nearest ally, $A e . s$. guttata, in being smaller, the spots on the throat less blackish, the ear-coverts slightly more reddish. Wings in $A$. $s$. guttata up to $67 \cdot 5$, and in adult males always over 60 , females smaller. In A. s. granti: Adult males not over $60.5 \mathrm{~mm}$.

Type: ô Snow Mountains, 2,000 feet, 25. viii.1910. A. S. Meek coll. No. 4636. In Tring Museum.

\section{Amalocichla incerta incerta (Salvad.).}

Eupetes incertus Salvadori, Ann. Mus. Civ. Genova, vii, p. 967 (1875-Arfak Mts.).

ơ우, ㅇ juv. Kofo (Anggi gidji), 11., 12., 15.vi.1928.

q juv. mountains near Ditschi, 16.vi.1928.

These are the birds which Stresemann called Pseudopitta incerta, and which we used to call Amalocichla brevicauda. We had quite overlooked Salvadori's Eupetes? incertus, while Reichenow (Journ. f. Orn. 1915, p. 129) was not acquainted with Drymoedus brevicauda de Vis 1894, which Rothschild and Hartert called Amalocichla brevicauda. In fact, the specimens from S.E. New Guinea, of which we now have 8 adults and 4 young from the Kotoi district, Upper Aroa River, Mambare and Angabunga Rivers, is so much like the Arfak incerta, that I cannot say for certain how it differs, unless the bill in brevicauda is generally longer. Dr. Mayr marked the iris as dark brown, bill black, feet greyish pink and pale grey-brown.

Weight 27 and $28 \mathrm{~g}$. Wings of the two adults of 80 , $977 \mathrm{~mm}$., in A. incerta brevicauda ô $81 \cdot 5,83 \cdot 5,84$, 우 $79,80,81 \mathrm{~mm}$.

Young birds are spotted like young Thrushes.

\section{Amalocichla incerta olivascentior subsp. nov.}

Upperside deeper, less rufous brown throughout, sides of head more blackish, less rufous brown, throat white with fine sooty brown tips to the feathers, underside more olivaceous, middle of abdomen only dirty white. "Iris dark. Bill black. Feet greyish black."

․ Weight $34 \mathrm{~g}$. Wing 76 , tarsus 31 , bill from base $20 \mathrm{~mm}$.

Type and unique specimen + Wondiwoi Mountain, 1,900 m., 14.vii.1928. No. 1517 Ernst Mayr coll.

Another, probably distinct, form is in the Tring Museum from Mount Goliath, which is somewhat intermediate in appearance between $A$. i. olivascentior and A. incerta brevicauda. Cf. Nov. Zool. 1913 (xx), p. 504. Both this and the Wondiwoi specimen have pointed tail-feathers, but their plumage is not juvenile, because we have young specimens moulting into the plumage of adults. 
182. Drymoedus superciliaris beccarii Salvad.

Drymoedus beccarii Salvadori, Ann. Mus. Civ. Genova, vii, p. 965 (1875-Arfak Mts.).

8 ํํํ Siwi, 2 oิ Ditschi, 우 Ninei, 1 ô, 2 우 Cyclops Mountains. Seen but not shot on Mount Wondiwoi. "Iris very dark brown. Bill black. Feet pinkish grey, pale flesh-colour, pinkish grey." Weight $\delta 4^{4}-57$, 우 35-42, once 47 g. On 24. viii.1928, Cyclops Mountains an egg almost ready for expulsion was found in a female. Wings of $88-92$, 우 79-82 $\mathrm{mm}$. The young in fluffy plumage is above rufous-chestnut with indicated paler spots, underside paler, abdomen whitish, wing-spots buff.

This form is a very much darkened subspecies of D. superciliaris of Cape York. We have thus :

1. D. superciliaris superciliaris Gould. Cape York Peninsula, N. Queensland.

2. D. superciliaris colcloughi Math. Roper River, Northern Territory.

3. D. superciliaris brevirostris De Vis. S.E. New Guinea, and apparently Aru Islands. (adjacens Math.)

4. D. superciliaris beccarii Salvad. Arfak Peninsula to Cyclops Mts.

\section{Eupetes castanonotus castanonotus Salvad.}

Eupetes castanonotus Salvadori, Ann. Mus. Cvv. Genova, vii, p. 966 (1875-Mt. Morait, on the northwestern coast of the Arfak Peninsula, 700-1000 m. high).

10 ํํ from near Siwi, $q$ and + juv. mountains near Ditschi, $q$ Ninei. "Iris dark, bill black, feet brownish black."

Weight from 66,67 in females to 83 in another female, but in males $69-77 \mathrm{~g}$. Wings ô $94-100$, 우 $90-96 \mathrm{~mm}$.

As known the rump and upper tail-coverts are blue in the male, but overspread with chestnut-red in the females.

The young female has the head and upper back dull dark chestnut-brown, lores and stripe behind eye dull black, above the latter an indicated paler streak, lower back and rump darker. Chin and throat white, rest of underside dull brownish black, wings and tail black, a metallic blue sheen on the rectrices and some of the inner remiges.

\section{Eupetes caerulescens caerulescens Temm.}

Eupetes caerulescens Temminck, Pl. Col. 574 (1835-New Guinea, type from Loto).

3 ธิ, 3 † Cyclops Mountains and Hol, 1 oิ above Wasior (Wandammen). Iris brown.

The females have the ear-coverts not so deep black or quite greyish blue and the black line which passes from the lores and the ear-coverts round the white throat is narrower and sometimes hardly visible.

Weight $44 \cdot 5-62 \mathrm{~g}$.

\section{Eupetes leucostictus leucostictus Scl.}

Eupetes leucostictus Sclater, Proc. Zool. Soc. London, 1873, p. 690, pl. 52 (Hatam, Arfak Mts.).

2 ô, 3 ㅇ Arfak Mountains, Lehuma and Ditschi Mountains.

The true Arfak leucostictus has always been rare in collections, and even now there is not a large series. The breast is bluish, not greenish.

Weight $41,46 \mathrm{~g}$. 
186. Eupetes leucostictus mayri subsp. nov.

This very striking new subspecies differs from $E$. leucostictus leucostictus Scl. from Arfak, in having the forehead to the end of the upper tail-coverts rufous chestnut instead of greenish-olive. The chest below the triangular black patch on the throat is greenish olive like the sides of the body. The black triangular throat-patch has more or less white edges to the feathers, but they are only a few in some specimens and absent in one, while they are more numerous and regular in E. l. leucostictus. "Iris dark brown. Bill black. Feet reddish grey, dirty flesh-colour."

Type: ô ad. Wondiwoi, 9.vii.1928. No. 1411 Mayr coll. Wings oึ 79-81, ㅇ 76-77 $\mathrm{mm}$.

Ernst Mayr sent 4 males, 1 unsexed, 2 우 from Wondiwoi, Wandammen Peninsula.

It is a pleasure to me to name this fine new subspecies in honour of the ardent collector, who was at once struck by its red back.

Nobody seems to have ever seen this bird, except in the Tring Museum. In fact we have had for many years a specimen without sex or indication of locality, once mounted and then dismounted. We then received a female from Mount Goliath from which we came to the conclusion that they were the females of leucostictus of which we had only one bad specimen! Our conclusion was, however, quite erroneous, as is now proved beyond doubt. We had also a specimen from the Mamberano River and two from Mount Kunupi, Weyland Mountains. We have thus a distribution from the Snow Mountains to the Mamberano and Wondiwoi Mountains.

Weight $41 \cdot 5-54 \cdot 5 \mathrm{~g}$.

187. Eupetes leucostictus loriae Salvad.

Eupetes loriae Salvadori, Ann. Mus. Civ. Genova, xxxvi, p. 102 (1896-Moroka, S.E. New Gnin za).

17 ડํํa․, 2 juv. Cyclops Mountains, September 1928.

This subspecies differs from E. leucostictus leucostictus only in the olivegreenish, not bluish, chest and unspotted black triangle on the jugulum.

Weight $48-54 \mathrm{~g}$.

We have also a male collected on the Rawlinson Mountains by the Rev. Keysser.

Some of the Cyclops Mountains specimens have somewhat shorter bills than S.E. Papuan specimens, but this character is not constant enough for separation.

Description of young, Nov. ZooL. 1903, p. 231.

188. Pomareopsis bruijni (Salvad.).

$\widehat{\jmath}+$ mountains near Ditschi, Arfak Mountains, 1,300 m.

189. Motacilla cinerea caspica (Gm.).

Parus caspicus (!) S. G. Gmelin, Reise d. Russland, iii, p. 104, Taf. 20, fig. 2 (1774-Enzeli, S. Caspian Sea).

Budytes Novae-Guineae Meyer, Sitzungsber. Isis Dresden, 1875, p. 74 (Arfak).

An unfortunate "Grey Wagtail" was met with at Siwi, 20.iv.1928. A specimen also from Arfak was received by A. B. Meyer, but this Wagtail is rare in New Guinea. 


\section{Saxicola caprata aethiops (Scl.).}

Poecilodryas aethiops Sclater, Proc. Zool. Soc. London, 1880, p. 66, pl. vii, fig. 1 (New Britain).

Pratincola caprata aethiops Rothschild \& Hartert, Nov. Zool. 1907, p. 467 ; Stresemann, Nov. Zool. xix, 1912, p. 322 !

$5 \hat{\delta}, 5$ ㅇ, the latter mostly terribly worn, Ifaar, September and October 1928. "Iris dark brown. Bill black, feet black, in both sexes."

Weight $19-20 \cdot 5 \mathrm{~g}$. Wings males 74-76, once (worn) only about $72 \mathrm{~mm}$.

\section{Locustella fasciolata (Gray).}

Acrocephalus fasciolatus G. R. Gray, Proc. Zool. Soc. London, 1860, p. 349 (Batjan).

3 \&, 1 unsexed Siwi, April and May.

This East Siberian migrant is rather uncommon in collections from New Guinea, but we had already received bad specimens from Dorey and Yamna on the north coast from Doherty.

\section{Acrocephalus arundinaceus subsp.}

In a swamp at Kofo (Anggi gidji) Reed-Warblers were observed 12.vi. and 14.vi.1928, and one good skin and a spoiled one were sent, both sexed as males. They were singing and the testes of one were large. This is probably a distinct subspecies, but as I cannot state differences from some Australian specimens (Acroc. arundinaceus australis) I cannot give a name to these Arfak birds. The wings measure 73 and (barely) $69 \mathrm{~mm}$., so probably the second (bad) specimen is a female. "Iris bleich graubräunlich."

The wing of $A$. arundinaceus cervinus De Vis from S.E. New Guinea is said to be $80 \mathrm{~mm}$. long, but as only one "female" (?) is known, and that was shot in July, when Australian migrants frequent New Guinea, our knowledge of this form is most insufficient.

(About the forms of these Reed-Warblers, see Treubia, vi, and Festschrift E. Hartert, Suppl. Journ. f. Orn. 1929.) In Salomonsen's article in the latter it must be mentioned that the bird which I had carefully refrained from naming after examination of one male only, and which he named harterti without further knowledge, came from the island of Luzon. Salomonsen says "Camarines," which probably is on Luzon, but who knows "Camarines," while Luzon is known to everybody.

\section{Orthonyx temminckii novaeguineae Mey.}

Orthonyx Novae Guineae A. B. Meyer, Sitzungster. k. Ak. Wien, lxix, p. 74 (1874-Arfak Mts. 3,500 feet).

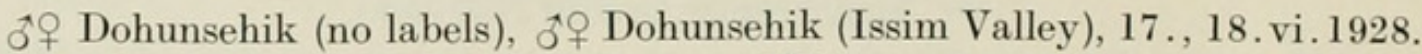
Weight ô 56, 57, ㅇ $49 \mathrm{~g}$. Iris dark brown. Wings ô 89, 92, 오 81, $81,82 \mathrm{~mm}$.

These birds differ from two females and a male from S.E. New Guinea (Mount Knutsford and Mount Scratchley), in having a little less white on the under side, the rump being slightly darker rufous-brown, and in having smaller dimensions. The S.E. form will therefore have to be called $O$. temminckii victoriana (van Oort, Notes Leyden Mus. xxx, p. 234, 1909, Mount Victoria, S.E. Papua), though the description does not quite agree, as it is said to be less white underneath, and the dimensions do not agree with our specimens. Wings 
in ours of 97 , $q 91$, also the bills are smaller in the Arfak form. We must therefore recognize 3 subspecies :

O. temminckii temminckii Ranzani : N.S. Wales to Queensland.

O. t. victoriana van Oort: S.E. New Guinea.

O. $t$. novaeguineae Mey. : Arfak Peninsula.

\section{Pomatorhinus isidori Less.}

Pomatorhinus isidori Lesson, Voy. Coquille, Zool. i, pl. 29 (1929), p. 680 (1930-Forest in neighbourhood of Dorey, Arfak Peninsula).

ऽํㅜ Momi, east coast of Arfak Peninsula, 우 Hol. "Iris light brown. Bill yellow and brown. Feet dark grey-brown."

\section{Neositta papuensis papuensis (Schleg.).}

Sitta papuensis Schlegel, Ned. Tijdschr. Dierk. iv, p. 47 (1871-Hatam, Arfak Mts.).

ợ Dohunsehik (Issim Valley), ô Lehuma, June 1928. " Ring round eye yellow, iris whitish yellow. Bill yellowish, tip black. Feet light yellow."

Weight 14-15 g. Wings ô 84 , ㅇ $84 \mathrm{~mm}$.

The two males, one with enlarged testes, have black crowns, the female a greyish white head with dark grey shaft-lines. This is in opposition to Schlegel's and Salvadori's descriptions, who described the female as black-headed, but I have no doubt that the black-crowned specimens are the males, as in N.p. albifrons (Rams.) from S.E. Papua.

\section{Climacteris placens placens Scl.}

Climacteris placens Sclater, Proc. Zool. Soc. London, 1873, p. 693 (Hatam, Arfak Mts.).

ô Dohunsehik 18. vi. 1928, No. 194.

\section{Coracina papuensis papuensis (Gm.).}

Corvus papuensis Gmelin, Syst. Nat. i, p. 371 (1788 - Ex Daubenton and Latham " hab. in Nova Guinea," doubtless western New Guinea, probably Arfak Peninsula).

Only two males from Ifaar, September 1928.

Weight 66,67 g. " "Iris dark."

\section{Coracina caeruleogrisea strenua (Schleg.).}

Campephaga strenua Schlegel, Ned. Tijdschr. Dierk. iv, p. 44 (1871-Jobi and Arfak Peninsula I select as the terra typica of the name strenua : Arfak Peninsula !).

A series of both sexes from Siwi, q Ditschi, series from the Cyclops Mountains.

I call these birds strenua, restricting the terra typica of that name to the Arfak Peninsula. I separate these birds from $C$. caeruleogrisea caeruleogrisea from the Aru Islands, because they are darker and more blue-grey than the distinctly paler Aru birds !

Specimens from S.E. New Guinea, as far as the Hydrographer Range, are somewhat intermediate, but more like the Aru form. Young birds have pointed and white-tipped rectrices. A young male from Siwi is partially albinistic, having the greater part of the downy head and neck and underside white; growing feathers are blue-grey, but some greater wing-coverts white.

In the Cyclops Mountains the sexual organs were greatly enlarged. 
199. Coracina lineata axillaris (Salvad.).

Grauculus axillaris Salvadori, Ann. Mus. Civ. Genova, vii, p. 925 (1875-Arfak Peninsula).

1 ô, 3 오 Siwi, April and May. "Iris bright light yellow, bill and feet black."

Weight $70-73 \cdot 5 \mathrm{~g}$.

The barring on the underside of the females reaches higher up in some specimens than in others.

\section{Coracina boyeri boyeri (Gray).}

Campephaga Boyeri G. R. Gray, Gen. B. i, p. 283 (1846-Ex Hombron \& Jacq., west coast of New Guinea, by which no doubt the coast of the Berau Peninsula was meant).

ô Siwi, 24.iv. 1928.

\section{Edolisoma incertum incertum (Mey.).}

Campephaga incerta A. B. Meyer, Sitzungster. k. Akad. Wien, lxix, p. 387 (1874 Jobi).

๙ิํㅜㅇㅗ Siwi, ô Cyclops Mountains.

Weight 54-57 g.

The female is much like the male, the slight differences are well described

by Stresemann. E. incertum sharpei seems after all not to differ, but we are handicapped by the want of Jobi specimens!

\section{Edolisoma morio mullerii Salvad.}

Edoliisoma müllerii Salvadori, Ann. Mus. Civ. Genova, vii, p. 927 (1875-New name for Müller's Utanata specimens).

1 ô juv., 5 \& $\mathrm{Hol}$ and Ifaar. No adult male was obtained.

Weight $61-71 \mathrm{~g}$.

\section{Edolisoma montanum montanum (Mey.).}

Campephaga montana (errore "montona," but corrected in same volume and year) A. B. Meyer Sitzungsber. k. Akad. Wien, lxix, p. 386 (1874-Arfak Mts.).

ऽํㅜ ad. Siwi, Ditschi and Cyclops Mountains. "Iris dark."

Weight $65-75 \mathrm{~g}$.

Wings ô 136-142 mm. In E. m. minus from S.E. New Guinea the wings rarely surpass 130 in males, and are mostly $129-130 \mathrm{~mm}$. Two females from Cyclops Mountains have more black on the throat, but this seems to vary somewhat.

\section{Edolisoma melan melan (Less.).}

Lanius melas Lesson, Man. d'Orn. i, p. 128 (1828-Dorey, Arfak).

ô Manokwari, ô Wasior, ồ Hollandia.

오 Siwi, 우 Momi, ㅇ Hollandia, ㅇ Cyclops Mountains. " "Iris dark."

\section{Lalage atrovirens atrovirens (Gray).}

Campephaga (Lalage) atrovirens G. R. Gray, Proc. Zool. Soc. London, 1861, pp. 430, 435 (Mysol).

2 ô Ifaar (Sentani Lakes), 23.ix. 1928.

Weight both $30 \mathrm{~g}$. 


\section{Pitta macklotii macklotii Temm.}

Pitta Macklotii Temminck, Pl. Col. 547 (1834 - From a specimen collected at Lobo Bay, Triton Bay).

ô ad. Siwi, Arfak Mountains, 1.v.1928.

2 ô ad. Momi, east coast of Arfak Peninsula, 30.vi.1928.

ô juv. Momi, 29.vi. 1928.

ㅇ ad. Manokwari, Arfak, 9.iv.1928.

These birds are typical macklotii, agreeing with others from Waigiu, Kapaur, the Lower Snow Mountains Range, the Fly River, S.E. New Guinea (except the utmost east, i.e. Milne Bay, Chad's Bay, Mullen's Harbour, to the Kumusi River, where $P$. m. loriae lives, and a mountain district on the Upper Aroa River, where P. m. oblita is found), and specimens from Simbang and Sattelberg, Huon Gulf.

While the island forms are very easy to understand (gazellae New Britain, Rooke Island, novaehibernicae New Ireland, finschi D'Entrecasteaux Islands, meeki Rossell Island, and the very closely allied kuehni and aruensis) we had not hitherto understood the forms from New Guinea itself. As it is the birds from the north coast : Humboldt Bay Region, Hollandia and Cyclops Mountains, and Potsdam Harbour, differ, as quite well described by Finsch in having a much brighter red nape, which reaches to the hind part of the eyes. The other points mentioned by Finsch are not characteristic for this form, but also found in P. m. macklotii.

A synonym of P. m. macklotii is also Pitta mackloti yorki Mathews, Nov. Zool. xviii, p. 299, 1912. P. m. macklotii is very rare in the northern Cape York Peninsula, and specimens from there do not differ from others from New Guinea. This form had already been named Pitta digglesi by Krefft, Ibis, 1869, p. 350. It is true that Krefft's specimen, though said to have been obtained at Cape York, might possibly have come from New Guinea, because the veracity of the collector was doubted by Krefft, but the name digglesi was given to the Cape York bird "if that should prove to be distinct from the New Guinea Pitta mackloti" ; Mathews could therefore not say that it was from New Guinea, and that the name "is therefore a synonym of $P$. m. macklotii," though it is virtually a nomen nudum.

\section{Pitta macklotii habenichti Finsch.}

Pitta Habenichti Finsch, Orn. Monatsber. 1912, pp. 102, 127 (near Potsdamhafen on the north coast of Kaiser-Wilhelmsland).

16 ऽิำ ad., 1 juv., Hol, Hollandia and Cyclops Mountains.

"Iris dark brown, bill black, feet greyish."

Weight $72-89 \mathrm{~g}$.

In one male, 8.viii.1928, the testes were enlarged. Wings ô 102-109, 110, 3 우 101, 108, $108 \mathrm{~mm}$.

All specimens are alike, no striking variation.

208. Pitta atricapilla atricapilla Quoy et Gaimard.

Pitta atricapilla Quoy et Gaimard, Voy. Astrolabe, Zool. i, p. 258, pl. 8, fig. 3 (1830-Dorey).

Pitta novae-guineae Müller \& Schlegel.

ô Momi, 29.vi., ơ Wasior, 24.vii.1928.

"Iris dark brown. Bill black. Feet greyish pink, pale brownish flesh." A fine series $\delta^{3}+$ Hollandia and Ifaar. 
These birds are in fine, fresh plumage, but in a few the colours of the underside are less dark and less vivid, the blue less bright.

A series from Dampier Island on the north coast of the Mandated Territory, collected in March 1914 by A. Eichhorn for A. S. Meek, were recorded by us as $P$. atricapilla atricapilla, but comparing them again with our now considerable series we find that the Dampier birds are duller, darker, on the breast, and the back is also slightly darker green in the series. It is therefore desirable in our opinion to call attention to this fact by a name, and I propose to call the Dampier bird

Pitta atricapilla hebetior, subsp. nov.

Type: ô Dampier Island, 9.iii.1914. No. 6789 of the Meek collections, collected by Albert Eichhorn.

\section{Melampitta lugubris Schleg.}

Melampitta lugubris Schlegel, Ned. Tijdschr. Dierk. iv, p. 47 (1871-Arfak Peninsula).

8 ડ우 ad. Lehuma, mountains near Ditschi, Dohunsehik in the Issim Valley. "Iris ô red, ㅇ brown. Bill and feet black."

Weight $41 \cdot 5,43,45,49 \mathrm{~g}$.

Wings " ô" 83-87, "우 "79-83 mm.

Compared with specimens from S.E. New Guinea the bills of the Arfak birds are generally very short, but there is not enough constancy to separate them.

Mellopitta lugubris rostrata Ogilvie-Grant 1913 was described from a single stout-billed individual, and is apparently a synonym of the typical Arfak form.

\section{Melampitta gigantea (Rothsch.).}

Mellopitta gigantea Rothschild, Orn. Monatsber. 1899, p. 137 (“ Mt. Moari," 3,000 feet. Mt. Moari is, however, not near Humboldt Bay, but on the east coast of the Arfak Peninsula near Oransbari, and it is Moari and not "Maori").

ô ad. Siwi, 15.v.1928. " "Iris dark brown. Bill and feet black."

Weight $205 \mathrm{~g}$. Wing about 143 , tail $140 \mathrm{~mm}$.

This specimen is entirely black. Its tail is much longer than that of the other known specimens, i.e. the type from Mount Moari, a male and a female from the Snow Mountains, one in the British, one in the Tring, Museum. The tails of our other two specimens are, however, very much worn off at the tip. Even in the male collected by Mayr, the webs of the rectrices, except towards the base, are disintegrated and the feathers wide. This might be looked upon as a generic character, but otherwise this rare bird is just a gigantic $M$. lugubris even the young being brown as in the latter.

Nothing is known about the habits and eggs of Melampitta!

\section{Caprimulgus macrurus yorki Math.}

Caprimulgus macrurus yorki Mathews, Nov. Zool. xviii, p. 291 (1912-Cape York).

ㅇ Momi, ôㅇ Wasior, ㅇ Hollandia, 4 ô Ifaar.

I do not see how these birds can be separated from the Cape York form, which Mathews called yorki. 
C. m. albolaxatus Rothsch. \& Hart., Nov. ZooL. xxv, 1918, pp. 323, 324, was described from the "chain of islands from New Britain to Vulcan (Manumudar, Voleano) Islands," and the type from Volcan island has the white on the outer rectrices much longer, i.e. $64 \mathrm{~mm}$. long, and the white patch on the outer primary touches the shaft.

In our large series there is no other specimen with so much white on the outer rectrices, and the white on the outer primary is also usually less extended.

Stresemann mentions specimens from New Britain, one from Ramu, and one from Stephansort with as much and more white $(64,65,73 \mathrm{~mm}$.), but it is accidental that his single specimens from Queensland and Arfak have only $40 \mathrm{~mm}$. long white! As it is, I fear that albolaxatus is based on specimens with abnormally much white, otherwise it must be restricted to the islands from New Britain to Vulcan Islands, and perhaps the adjoining coast of Papua, but it is not found at Hollandia, Ifaar and Arfak, where C. m. yorki occurs.

\section{Collocalia fuciphaga mayri subsp. nov.}

This apparently new form is nearest to $C$. fuciphaga hirundinacea Stres., but the tarsus is more thickly covered with dark brown feathers, all over, by which it differs also from all other known forms of fuciphaga. The wing measures about $110 \mathrm{~mm}$.

Type a unique male specimen from Siwi, Arfak Mountains, shot 25.v. 1928.

It is perfectly true that none of our $C$. fuciphaga hirundinacea from the Setekwa River (terra typical of hirundinacea) has such thickly covered tarsi. I am obliged to Dr. Stresemann for his comparing our single specimen with his hirundinacea. Unfortunately the wings and tail are slightly damaged.

\section{Collocalia esculenta esculenta (L.).}

Hirundo esculenta Linnaeus, Syst. Nat. ed. x, i, p. 191 (1758 - China, errore. Terra typica Amboinaex Rumphius).

3 ㅇ only from Siwi, 14.v. and 29.iv. 1928.

Weight 6.5 and $7 \mathrm{~g}$.

\section{Hemiprocne mystacea mystacea (Less.).}

3 ㅇ ad. Ifaar. Wings $231-234.5 \mathrm{~mm}$. Eggs in ovary very large.

ô Ninei, ô Wasior, 25. vii.1928.

Weight $71 \mathrm{~g}$.

\section{Lyncornis papuensis (Schleg.).}

Caprimulgus papuensis Schlegel, Nederl. Tijdschr. Dierkunde, iii, p. 340 (1866- Salwatti and neighbouring coast of New Guinea).

One bad specimen knocked over by natives at Wasior (Wandammen), 19.vii.1928. Wing about $190 \mathrm{~mm}$.

(Mathews in “'Syst. Av. Australasianarum," i, p. 395, gave quite a misleading and fanciful account of the status of this species. He says that L. papuensis (Schleg.) was described from Salwatti and that the form from the Papuan "mainland" is a different subspecies. There is, however, no reason whatever for this construction. Schlegel described papuensis from Salwatti and the 
western B rau Peninsula, not from Salwatti alone! From that one must infer that Salwatti and New Guinea specimens are alike, and Mathews, who has not compared the specimens from various localities, had no right whatever to assume that papuensis was restricted to Salwatti, and that New Guinea itself held another subspecies.)

\section{Aegotheles cristata affinis Salvad.}

Aegotheles affinis Salvadori, Ann. Mus. Civ. Genova, vii, p. 917 (1875-Arfak Mts.).

5 ô, 1 ㅇ Siwi, mountains near Siwi, May 1928. "Iris dark brown. Bill blackish brown and black. Feet greyish pink, whitish brown."

Weight $41 \cdot 5-48 \cdot 5,53,60 \mathrm{~g}$. Wings ô 130-136, 우 $139 \mathrm{~mm}$.

It is with great satisfaction that I register this fine little series of a most rare bird, of which hitherto only the single type seems to have been known. Cf. Hartert, Ibis, 1896, p. 375, pl. vii ; Tierreich, Lief. i, p. 11, 1897.

This form is nearest to Ae. c. bennetti from S.E. New Guinea, but the markings on the upperside are coarser, those on the crown generally larger, the light nape-band generally wide, but sometimes only indicated, the ear-coverts throughout less blackish, more or less rufous, bars on tail generally sharp and somewhat wider. Larger, wings of Ae. c. bennetti 121-129 mm.

Ae. c. wiedenfeldi Laubm. is elosely allied to bennetti, but larger, tail longer, wings about $1 \mathrm{~cm}$. longer, markings fine as in bennetti (not coarse as in affinis), generally darker, nape-band often wider, white or brown. We have it from Simbang, the Sattelberg, Holnicote Bay and the Kumusi River !

It is unavoidable to treat these forms as subspecies of the Australian novaehollandiae, or rather cristata as it is now called, because of a few months priority !

In Ae. c. affinis the underside is whitish, throat to breast barred with brownish black, but in some specimens the throat down to the breast is rusty-buff, and along the middle a more or less unbarred brownish buff line. This is not dependent on sex or age. Abdomen and under tail-coverts are white.

\section{Aegotheles albertisi albertisi Scl.}

Aegotheles albertisi Sclater, Proc. Zool. Soc. London, 1873, p. 696 (Arfak Mts.). Aegotheles dubius A. B. Meyer, Sitzungsber. k. Akad. Wien, xlix, p. 75 (1874-Arfak Mts., 3,550 feet).

1 o mountains near Siwi, 1 ô Lehuma, 1 ㅇ mountains near Ditschi, $1 \hat{\sigma}$ Kofo (Anggi gidji), Ernst Mayr coll., 1 ô Arfak Mountains, 2,000 m. Shaw Mayer coll. "Iris brown. Bill blackish. Feet flesh-colour, whitish, pale pink."

Weight $25,30,30 \cdot 5 \mathrm{~g}$. Wings $119,120,123 \mathrm{~mm}$.

The colour of the upperside varies from foxy rufous to rufous brown, dark chestnut to almost black. Most specimens have a white collar, but sometimes it is obsolete, in one female quite absent.

Ae. albertisi salvadorii Hart. 1892 (synonym Ae. rufescens Salvad. 1896, both described from the Moroka district in S.E. New Guinea !) is a very closely allied form, differing only in the somewhat less dark and less bright colour of the upperside from true albertisi! The upperside varies from cinnamon-red 
to brownish chestnut and blackish brown, the white collar is mostly very distinet, but sometimes quite obsolete. Wings 113-122, once $126 \mathrm{~mm}$. We have a wonderful series of 34 specimens.

\section{Aegotheles (?).}

1 ô Wondiwoi (Wandammen), 10.vii.1928.

Weight $44 \cdot 5 \mathrm{~g}$.

"Iris brownish. Bill dark horn-colour. Feet pale pink."

I do not venture to say what this bird is. It has the markings of Ae. albertisi salvadorii, but the wings are $138 \mathrm{~mm}$. long ! It is a young bird, as the six rectrices that are left and the tips of the wings show. The ear-coverts are rather pale cinnamon rufous.

If more material were to hand it would probably become clear whether this bird belongs to a very large subspecies of Ae. albertisi, or whether it is a giant (or another species?).

\section{Aegotheles insignis insignis Salvad.}

Aegotheles insignis Salvadori, Ann. Mus. Civ. Genova, vii, p. 916 (1875-Hatam, Arfak Mts.); Hartert, Ibis, 1896, p. 375, pl. vi.

ㅇ Lehuma, $q$ above Ditschi, ô Dohunsehik, ô Wondiwoi.

Of this form as far as I know, only the type had hitherto been recorded, though a $q$ from Mount Kunupi, Weyland Mountains, 6,000 feet, collected by Pratt Bros. and recorded by Lord Rothschild as Ae. pulcher, belongs, in my opinion, to Ae. insignis insignis, but this requires confirmation from more specimens. The iris is described as ochre, light ochre, dark ochre, and dark brown, bill brownish horn, feet pale pink. Wings ô 164, 170, 우 $160,162 \mathrm{~mm}$. The Weyland Mountains bird " $q$ " $165 \mathrm{~mm}$.

In 1898, Bull. B.O. Club, viii, p. viii, I described from a single specimen from the "mountains of British New Guinea" Aegotheles pulcher. This was bought in London, but was collected by Emil Weiske, the preparation being unmistakable, and almost certain came from the Upper Aroa River, where Meek found this bird later on quite common. When describing it nothing was known of Ae. insignis except the type, which I had, a few years before, examined, through the kindness of Dr. Gestro. I then stated the smaller size and certain colour differences. In 1907, Nov. ZooL. xiv, pp. 456, 457, Lord Rothschild and I said clearly that pulcher is "doubtless a subspecies of $A e$. insignis from Arfak, which is very similar."

We there described the stupendous variations in the colour and markings, and in fact they are the same in the two subspecies, though among the few specimens from Western New Guinea there are not any so light and bright as some of the pulcher are.

In fact there is no difference between the two races, except the larger size of pulcher, which have wings ranging from 166 to $180 \mathrm{~mm}$., against 155 (type), $160,162,164,165,170 \mathrm{~mm}$. in insignis insignis. From the Aroa River I have examined 34 specimens.

The insignis from the Weyland Mountains is the darkest specimen seen, but one from Avera on the Upper Aroa River is almost quite as dark. 
220. Podargus papuensis papuensis Quoy et Gaim.

Podargus papuensis Quoy et Gaimard, Voy. Astrolabe, Zool. i, p. 207, Atlas pl. 13 (1830-Dorey, Arfak).

of rufous-brownish. ô Wasior, 23.vii.1928.

Weight $325,445 \mathrm{~g}$.

Mathews described the Waigiu form as $P$. p . conigravi, saying that the specimens were "distinctly darker," but he had no material justifying this statement. On the other hand, it seems that the Cape York form (Nov. Zool. xviii, p. 281), P. p. baileyi and $P$. p. rogersi Mathews, is in the series a lighter form, and probably the Merauke form P. p. pumilus Stres. (Orn. Monatsber. 1927, p. 87) is also different, and possibly the Aru and Mysol birds may belong to it or to other small forms.

The iris is described as yellow, in one red (probably blood ?).

\section{Podargus ocellatus ocellatus Quoy et Gaimard.}

Podargus ocellatus Quoy et Gaimard, Voy. Astrolabe, Zool. i. p. 208, Atlas pl. xiv (1830-Dorey, Arfak).

1 ô Cyclops Mountains, 29.viii.1928. " Iris dark brown."

Weight $156 \mathrm{~g}$.

\section{Merops ornatus Lath.}

ô Siwi, 27.iv. 1928. In beautiful fresh plumage.

" + ? " Manokwari, 9.iv.1928. (Is evidently a female.)

우 Wasior (Wandammen), 19.vii.1928. In moult.

A migrant from Australia.

\section{Merops philippinus salvadorii Mey.}

Merops salvadorii A. B. Meyer, Ibis, 1891, p. 294 (New Britain).

ㅇ ad. Ifaar, 16.ix.1928. Weight $43 \mathrm{~g}$. Ovary small. "Iris red."

This specimen is very little more yellowish on the upperside than $M . p h$. philippinus, but the underside is much less green, rather golden brownish ; only the middle of the abdomen is pale green. The stripe under the black band along the sides of the head is very pale blue, but there are specimens of $M$. ph. philippinus in which it is equally pale. Not known so far west.

\section{Eurystomus orientalis crassirostris Scl.}

Eurystomus crassirostris Sclater, Proc. Zool. Soc. London, 1869, p. 121 ("Solomon Is." errore, terra typica New Britain).

ํํ오 Siwi, ô Wasior.

Weight 180, 185, $195 \mathrm{~g}$.

("E. o. waigiouensis" is erroneously kept as a separate subspecies by Mathews.)

\section{Eurystomus orientalis pacificus (Lath.).}

A specimen from Manokwari, 9.iv.1928. Further specimens were wisely not collected. 
226. Rhyticeros plicatus ruficollis (Vieill.).

우 Momi, ơ Hol.

227. Alcyone azurea ochrogaster Rchw.

Alycone ochrogaster Reichenow, Journ.f. Orn. 1903, p. 149 (Kaiser-Wilhelmsland, type from Ramu). Alcyone azurea distincta, Mathews B. Austr. vii, p. 94 (1918-Humboldt Bay, North New Guinea).

$2 \widehat{\jmath}, 1$ 우 Ifaar, September and October.

Weight $33,35,36 \mathrm{~g}$.

The form from the Mandated Territory and the north coast as far as Ifaar and Humboldt Bay is very much lighter on the underside and distinguishable at first glance.

\section{Ceyx lepidus solitarius Temm.}

Ceyx solitaria Temminck, Pl. Col. 595 (1836-Lobo Bay).

오 Siwi, ㅇ W Wasior (Wandammen).

Weight $14 \cdot 5,15 \cdot 5 \mathrm{~g}$.

It seems a bit daring to call these smaller, slender-billed birds subspecies of lepidus, but $C$. $l$. sacerdotis R. \& H. connects the two supposed species wonderfully. I therefore follow Stresemann in treating this form and a number of allies as subspecies of lepidus. Ceyx is of course of masculine gender, though we have mechanically followed the Catalogue of Birds, Salvadori and others, in treating it as feminine.

\section{Alcyone pusilla pusilla (Temm.).}

Ceyx pusilla Temminck, Pl. Col. 595 (1836-Lobo Bay).

๙ิ우 Ifaar, ㅇ Hollandia.

Weight 13 and $14 \mathrm{~g}$.

(Mathews admits a subspecies assimilis Diggles, Trans. Phil. Soc. Queensland, ii, p. 6, 1873, described from Cape York, but according to Mathews from the Aru Islands. I fail to see how he can make this out from the description, as the Cape York bird is very much like the Aru bird, which seems not to differ from typical pusilla.)

\section{Syma torotoro torotoro Less.}

Syma torotoro Lesson, Bull. Sci. Nat. Férussac, xi, p. 443 (1827-Dorey, Arfak).

2 우 Siwi, 2 ô Wasior (Wandammen), 2 의 and $1 \hat{\jmath}$ juv. (bill quite black) Hollandia, ô Ifaar, Sentani Lakes.

Weight $44,45,49 \cdot 5,52 \mathrm{~g}$.

Wings ô 81,81 , 우 $79,80,81,82,84 \mathrm{~mm}$.

These are the only Syma that have come to hand. The treatment of this genus and its forms has so far been varied and sometimes peculiar. The form named megarhyncha has been treated as a different species by Rothschild \& Hartert, Stresemann, Mathews and others.

In my opinion, however, megarhyncha is just a mountain form, representing the smaller ones on the hills; thus we have on the mountains of S.E. New Guinea and on the Snow Mountains the big megarhyncha, on the Sattelberg (and probably other hills of N.E. Papua) the sellamontis. The latter is hardly distinguishable from $S$. $t$. torotoro, but a little larger, wing $\delta 84$, according to Stresemann (once) 88 , $+86,87,89 \mathrm{~mm}$., bill slightly larger. In some adult 
males the bill is entirely yellow, but even old females have the top of the culmen, at least near the tip, black, but one female has an entirely yellow bill.

Mathews named specimens from the Lower Snow Mountains Syma torotoro pseustes (B. Austr. vii, p. 113, 1918), because they were named differently by various authors. He also said they differed from meeki by having bluer tails and darker upperside, but this seems not to be the case.

Therefore, as far as I could judge at present, the following subspecies can be distinguished :

Syma torotoro torotoro Less. Arfak to Sepik River, and apparently Western Papuan Islands.

Syma torotoro tentelare Hart. Aru Islands.

Syma torotoro meeki R. \& H. S.E. New Guinea, west to Lower Snow Mountains, north to Kai Peninsula (Simbang, Heldsbach).

Syma torotoro ochracea R. \& H. D'Entrecasteaux Islands.

Syma torotoro flavirostris Gould. North Queensland.

Syma torotoro megarhyncha Salvad. Mountains of S.E. New Guinea and Snow Mountains. (Synonym S. torotoro wellsi Math. 1918.)

Syma torotoro sellamontis Rchw. Mountains of N.E. New Guinea.

(Mathews named also a specimen from Humboldt Bay in the British Museum of the true S.t. torotoro, calling it Syma torotoro connectens. In his Syst. Av. Australas. p. 371 , he places this name as a synonym of S. megarhyncha sellamontis. The only specimen I found in the Brit. Mus. is, however, as I have said, $S$. $t$. torotoro and not sellamontis! It must be mentioned that the subspecies of Syma described by Mathews in the Brit. Mus. are not named on the labels, nor are the type specimens marked!)

\section{Melidora macrorhina macrorhina (Less.).}

Dacelo macrorhinus Lesson, Bull. Sci. Nat. Férussac, xii, p. 131, 1827, and Voy. Coquille, Zool. Atlas pl. 31 bis, 1829 (both the same birds, collected by Lesson at Dorey).

1 "ㅇ" Siwi, 24.v.1928. This specimen is not adult, as shown by the partially brown underside. The spots on the tips of the black feathers of the crown are not brownish green, but greenish blue, a good many feathers on the crown are wanting. It seems to me that this specimen must be an immature male.

Unfortunately the only specimen from Arfak sent.

In a large series from Arfak, Snow Mountains and S.E. New Guinea the wings measure 114-122 $\mathrm{mm}$.

\section{Melidora macrorhina jobiensis Salvad.}

Melidora jobiensis Salvadori, Orn. Pap. e Molucc. i, p. 502 (1880—Jobi Island).

우 Hol, 4. viii. 1928.

2 ô ad., 1 ô juv., 4 q Ifaar, September and October. Wings 117-124 mm.

Weight $90-125 \mathrm{~g}$ ! On 19.ix.1928 a 우 with very large eggs was shot.

The form from Jobi and along the north coast to the Astrolabe Bay. It has been recognized that the males are practically indistinguishable, while the females have no greenish tips or fringes to the feathers of the crown, but in a female from Ifaar (No. 2599) they are present, though very narrow. This subspecies is therefore not absolutely constant, but must be recognized. The 
S.E. New Guinea has twice been named: M. goldiei Ramsay 1876, M. collaris Sharpe, 1877, the latter because it had a white nuchal collar, which is usually very prominent in S.E. New Guinea, but sometimes obsolete. On the other hand, the white nuchal band is often obsolete or quite absent in Arfak and in jobiensis, along the north coast, but if the skins are made with too short a neck, it is difficult to make out.

With regard to the remarks in Nov. ZooL. 1901, p. 149, it must be said, that "Mount Maori" (rectius Mount Moari) is not near Humboldt Bay, but on the east coast of the Arfak Peninsula!

\section{[Melidora macrorhina waigiuensis subsp. nov.}

Specimens from Waigiu are evidently larger: Wing ô 128, 126, q 132 in a juvenile of $124 \mathrm{~mm}$. I therefore think I am justified in naming the Waigiu form as above. The female has only very faintly indicated greenish glossy edges to the feathers of the crown.

Type : + not quite adult Waigiu, 26.xii.1902. John Waterstradt coll.]

\section{Sauromarptis gaudichaud (Quoy et Gaim.).}

Dacelo Gaudichaud Quoy et Gaimard, Voy. Uranie, Zool. p. 112, pl. 25 (1825-New Guinea).

ㅇ Manokwari, ㅇ Siwi, ô Wasior, $2 \hat{\jmath}, 1$ 우 (ovary medium) Ifaar, $2 \hat{\jmath}$, 3 우 Hol.

\section{Halcyon sancta sancta Vig. \& Horsf.}

Halcyon sanctus Vigors \& Horsfield, Trans. Linn. Soc. London, xv, p. 206 (1827-Australia).

(It seems to me that there is only one form all over Australia, the names ramsayi Mathews, westralasianus Campbell and confusus Math. being synonyms.)

2 ô Manokwari, ôto Siwi, 2 \& Hollandia. Sexual organs small.

Two specimens from Siwi and Manokwari, April 1928, are extremely bluish. Such blue birds have been named westralasianus and ramsayi, but I cannot see that they are geographical forms, nor anything else than invididual variations, and most of them are in abraded condition; the type of ramsayi from N.W. Australia, August, however, is in beautifully fresh plumage. Similarly blue specimens we have, for example, from Bathurst in N.S. Wales, Sudest Island, March, and Talasea, New Britain, May 5th.

(Mathews applies the name Alcyone ruficollaris Bankier to Halcyon sancta, but this is quite impossible, as a glance at the description shows. Obviously Bankier's bird was an Alcyone, the legs being described as reddish-yellow, while Halcyon sancta has brown feet; in fact ruficollaris is a synonym of Alcyone azurea pulchra, and the first words "plumage glossy green " are a misprint for glossy blue, all the rest of the diagnosis referring to A. a. pulchra.)

\section{Tanysiptera hydrocharis galatea Gray.}

Tanysiptera galatea Gray, Proc. Zool. Soc. London, 1859, p. 154 (Dorey).

2 ๙ิ, 3 o Momi. " Iris deep brown. Bill red. Feet dirty yellowish green," Weight $60-67 \mathrm{~g}$.

๙ิ Wasior, 19. vii. 1928 ,

Weight $64 \mathrm{~g}$. 


\section{Tanysiptera hydrocharis meyeri Salvad.}

Tanysiptera meyer Salvadori, Ornit. Pap. e Mol., Agg. p. 54 (1889-Kafu).

우 ad. Ifaar, 2.x.1928.

Weight $63 \mathrm{~g}$.

Ovary much enlarged.

ô juv. Hollandia, 12.viii. 1928.

237. Tanysiptera sylvia mira subsp. nov.

Differs from $T . s$. salvadoriana in having the blue outer webs to the elongated middle rectrices and outer upper tail-coverts of a deeper, somewhat purplish blue, instead of a dull, paler, almost greenish blue. Also the underside is slightly richer rufous cinnamon.

Weight ô 55, ㅇ $54 \mathrm{~g}$. Wings $q$ about $100 \mathrm{~mm}$., but all three moulting.

Type : ô Ifaar, 30.ix.1928. No. 2715 Mayr coll.

2 o Hollandia, 1 ô Ifaar.

T. s. salvadoriana has hitherto only been known from S.E. New Guinea, and very few specimens are in collections. It is therefore quite surprising to find the form on the north coast near Humboldt Bay !

It is of course not surprising that the specimens differ slightly from salvadoriana. Unfortunately all three are moulting and no more were collected.

\section{Cacomantis castaneiventris arfakianus Salvad.}

Cacomantis arfakianus Salvadori, Orn. Pap. e Mol., Aggiunte, i, p. 49 (1889-Arfak Mts. and Western Papuan Islands).

7 ô Siwi, 1 ô Kofo, Anggi gidji, $q$ mountains near Ditschi, ㅇ Wondiwoi, ô pull. from nest of Sericornis arfakiana, 1 q juv. Siwi.

The old birds do not differ in colour from our series of $C$. c. weiskei Rehw. = C. c. bihagi Math. ${ }^{1}$ ), but their wings are 109-115, mostly 110-112, the Wondiwoi ㅇ only $103.5 \mathrm{~mm}$., while in the S.E. subspecies (weiskei) the wings range from 111 to 118 and even $119 \mathrm{~mm}$. In the young birds from Arfak the underside is greyish brown, middle of abdomen white or whitish, while in the south-eastern form it is uniformly cinnamon-brown all over the underside.

The iris of the adults is reddish grey or brown, the eyelid has a yellow edge.

All these birds hardly differ from $C$. castaneiventris castaneiventris, except that the four specimens I have seen of the latter are underneath paler-but some Arfak ones are just as pale!

\section{Cacomantis variolosus infaustus Cab. \& Heine.}

Cuculus assimilis Gray 1858, nec Brehm, 1831.

Cacomantis infaustus Cabanis \& Heine, Mus. Hein. iv, p. 23 (1862-Misol !).

Cacomantis variolosus infaustus Hartert, Nov. Zool. xxxii, p. 167 (1925).

Two quite young birds (pulli) taken from nest of Malurus alb. alboscapulatus 30 .iv. and 16.v.1928.

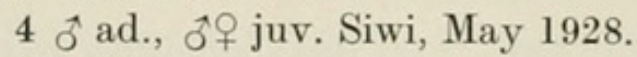

Weight $26 \cdot 5-38 \mathrm{~g}$.

"Iris of adults dark brown or brownish, edge of eyelid yellowish grey,

1 Cf. Nov. Zool. xxxii, 1925, pp. 170, 171. 
yellow, grey. Iris of young whitish grey or pale light brown." Wings of adult males $115-124 \mathrm{~mm}$.

One of the adults is underneath almost pure grey, vent and under tailcoverts rufous, the other three (perhaps not quite so old) have the whole underside from the jugulum downwards suffused with rufous.

\section{Cacomantis pyrrhophanus excitus R. \& H.}

Cacomantis excitus Rothschild \& Hartert, Nov. Zool. xiv, p. 436 (1907-"In montibus Novae Guineae meridionalis orientalis").

Cacomantis cineraceus excitus Hartert, Nov. Zool. xxxii, 1925, p. 173.

Cacomantis pyrrhophanus excitus Hartert, Nov. Zool. xxxiii, 1926, p. 56 !

1 ô ad. above Ditschi, Arfak Peninsula Mountains, 30.v. 1928. " "Iris dark brown, bill black, feet brownish yellow."

Weight $42 \mathrm{~g}$. Wings $140 \mathrm{~mm}$.

Hitherto only known from the mountains of S.E. New Guinea, and rare in collections !

241. Chalcites ruficollis (Salvad.).

Lamprococcyx ruficollis Salvadori, Ann. Mus. Civ. Genova, vii, p. 913 (1875-Arfak Mts.).

1 ㅇ Wondiwoi, Wandammen Peninsula, 1,300 m., 13.vii.1928.

Weight $23.5 \mathrm{~g}$. Ovary very large !

\section{Chalcites meyerii (Salvad.).}

Chrysococcyx splendidus Meyer, nec Gray!

Chrysococcyx meyerii Salvadori, Ann. Mus. Civ. Genova, vi, p. 82 (1874-Hatam, Arfak Mts.).

4 ô, 3 $\uparrow$ Siwi and Lehuma, Arfak, 1 Cyclops Mountains with enlarged testes. Weight $17-21 \cdot 5 \mathrm{~g}$.

As is well known, the female has the forehead to beyond the eyes chestnutrufous, the male dark metallic green.

\section{Caliechthrus leucolophus (Müll.).}

Cuculus leucolophus S. Müller, Verh. Nat. Gesch. Ned. Indie, Land- en Volkenkunde, p. 22 (1840Lobo Bay).

1 adult, 1 juv. (in moult, plumage partially still softer and fluffier and brownish black, instead of glossy blue-black) Hollandia and Cyclops Mountains.

\section{Cuculus pallidus (Lath.).}

Columba pallida Latham, Index Orn., Suppl. p. Ix (1801-New South Wales, descr. from one of Watling's drawings).

1 ở juv. Momi, 25.vi.1928.

\section{Microdynamis parva (Salvad.).}

Eudynamis parva Salvadori, Ann. Mus. Civ. Genova, vii, p. 486 (1875-Said to be from Tidore, but apparently come from Arfak!).

1 ô ad. Ifaar, 1.x.1928. " Iris red. Bill and feet black."

This specimen is darker on the underside, and a little darker above, than our specimens from S.E. New Guinea, which, however, vary. As a quite young bird from Mount Moari (Arfak Peninsula) and one from the island of Ron in 
the Geelvink Bay are also more or less darker, I think it is quite possible that the south-eastern may be separable, but from the scanty material so far available this cannot be done.

\section{Centropus menbeki menbeki Less. \& Garnot.}

Centropus menbeki Lesson et Garnot, Voy. Coquille, Zool. Atlas, pl. xxxiii, p. 600 (1828-N.W. New Guinea, meaning Arfak).

$2 \hat{o}$ ad. Ifaar.

Weight 430, $460 \mathrm{~g}$.

ํㅜㅇ Wasior, ô juv. Momi. "Iris in adults red, young yellowish brown."

\section{Centropus nigricans (Salvad.).}

Polophilus nigricans Salvadori, Ann. Mus. Civ. Genova, ix, p. 17 (1876-Naiabui and Yule Island).

$3 \hat{\jmath}, 1$ q Ifaar, September and October 1st, 1928. "Iris red, bill black, feet dark grey. Testes large, ovary very large."

Weight ôे 180, 210, 225, 우 $300 \mathrm{~g}$. Wings ô 197-200, ㅇ $220 \mathrm{~mm}$.

It is known that in these Papuan Centropus the females are generally larger than the males.

(Mathews treats nigricans as a subspecies of spilopterus, but this cannot be accepted. In fact it is much nearer to Centropus phasianinus, having the light brown markings on wings and tail throughout life, and it may be looked upon as a subspecies of the latter, though it appears in Mathews' list in a different genus.)

\section{Centropus bernsteini Schleg.}

Centropus bernsteini Schlegel, Ned. Tijdschr. Dierk. iii, p. 257 (1866-Either Salwatti or opposite coast region of Papua, but in vol. iv, p. 11, it is said that the type came from Salwatti ; it has, however, never again been found on that island, but in many localities in northern and southern Papua, as far east as Simbang and Sattelberg. It was therefore indefensible for Mathews to restrict its habitat to Salwatti).

5 ô ad., 2 ㅇ ad., Ifaar, 1 q juv. Momi. "Iris dark brown! Bill and feet black or blackish."

Weight ô 130-150, ㅇ 160 and $200 \mathrm{~g}$. Wings ô 168-179, 우 179-182 mm.

(Mathews' experiment to consider both $C$. nigricans and $C$. bernsteini to be subspecies of spilopterus is a bad error, as both occur in the same areas and have fundamental differences.)

\section{Lorius lory lory (L.).}

Psittacus lory Linnaeus, Syst. Nat. Ed. x, i, p. 100 (1758 - " Habitat in India orientali," ex Edwards pl. 170. Substituted terra typica Berau Peninsula).

우 Ditschi, 8 ôㅇ Siwi. "Iris yellow."

Weight $165-200 \mathrm{~g}$.

\section{Lorius lory rubiensis Mey.}

Lorius erythrothorax rubiensis A. B. Meyer, Abh. Mus. Dresden, No. 3, 1892-93, p. 10 (1893-Rubi, S. Geelvink Bay).

ô Wasior, coast Wandammen Peninsula, 19.vii.1928. "Iris yellow." Weight $200 \mathrm{~g}$.

Differs at a glance from $L$. lory lory by the blue-black colour on the underside being much more restricted, not covering the breast, is, however, very 
closely allied to erythrothorax, but is much smaller-shorter wing. To rubiensis belong also our specimens from the Southern Snow Mountains, and the bird already mentioned by Lord Rothschild from the Wanggar River, 20 miles from the coast, south of Geelvink Bay, thus almost terra typica; the Snow Mountains specimens were erroneously called erythrothorax in Nov. ZooL. 1913, p. 484.

\section{Lorius lory viridicrissalis Beaufort.}

Lorius cyanauchen viridicrissalis Beaufort, Nova Guinea, vol. v, p. 403 (1905 ${ }^{1}$-Lake Sentani, Humboldt Bay and Tami. Terra typica Sentani lake!).

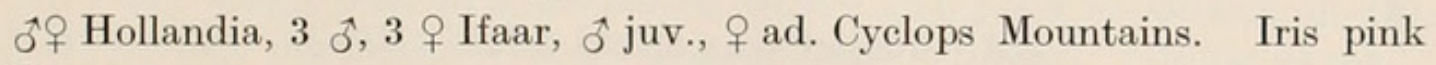
or red.

Weight 160-200, once $152 \mathrm{~g}$.

These birds are of the form which Rothschild and I described from Takar, further west on the north coast. The under wing-coverts are black with hardly any blue in the males, while females show usually more and well pronounced blue on the under wing-coverts. Also the under tail-coverts are deeper and more purplish blue in adult males, in the females, however, lighter, almost approaching sky-blue, or verditer blue, but not green! Therefore the name is unfortunate, being based on exaggeration, and actually quite unfit for adult males.

Young birds have a yellow bar across the under wing-coverts. Wings ô $162,162,163,163$, 우 $159,160,163 \mathrm{~mm}$.

\section{Chalcopsitta duivenbodei duivenbodei D ıb.}

Chalcopsittacus duivenbodei Dubois, Bull. Mus. Roy. d'Hist. Nat. Belg. iii, p. 113, pl. v (1884New Guinea. I substitute as terra typica Tana Mera, because the specimens of North Coast species received by van Renesse van Duivenbode mostly came from Tana Mera).

One unsexed Hollandia, 1 우 Ifaar.

Weight $200 \mathrm{~g}$. " Iris red, bill and feet black."

\section{Eos fuscata incondita Mey.}

Eos incondita A. B. Meyer, Zeitschr. ges. Orn. iii, p. 6, pl. i (1886-S.E. New Guinea and Jobi).

Five red and 1 yellow $\widehat{\jmath}+$ Ifaar, 1 $\hat{\jmath}, 2$ 우 Cyclops Mountains.

Weight 160 , once $150 \mathrm{~g}$.

While the colour differences pointed out by Meyer do not hold good, it is true that all specimens are larger than those from the Berau (Arfak) Peninsula and Salwatti.

\section{Trichoglossus hammatodus haematodus (L.).}

Psittacus haematod. (abbreviation for haematodus, in order to save a line; the same was done with leucoryn. for leucorhynchus, mascarin. for mascarinus, dichotom. for dichotomus and others) Linnaeus, Mantissa Plantarum, p. 524 (1771-Ex Brisson and Edwards, "Habitat in Amboina"!).

$1 \hat{\jmath}, 2$ ㅇ Manokwari, 3 ô, 3 ㅇ mountains near Siwi, $2 \hat{\jmath}, 1$ 우 Wasior, on coast of western Wandammen Peninsula.

It is interesting to find the Wasior form to be the same as the Arfak one. The fauna of Wandammen is curious, the birds of the plains being Arfak forms, mountain birds mostly more eastern ones (as along the north coast), with a few locally specialized peculiar forms.

Weight 100, 110, 115 (several), 120, 125, 135, 140 g., the latter three Wasior. Wings 138-142 mm.

\footnotetext{
1 The reprints are not dated!
} 
255. Trichoglossus haematodus intermedius R. \& H.

Trichoglossus haematodus intermedius Rothschild \& Hartert, Nov. Zool. viii, p. 70 (1901-Astrolabe

Bay, type Stephansort).

ô Ifaar, 1 Hollandia.

Weight $155,160 \mathrm{~g}$.

This form is larger than haematodus from Arfak and Wasior. Wings 150, $156 \mathrm{~mm}$. The less bluish stripes on cheeks and ear-coverts are not always well pronounced, though generally recognizable.

\section{Oreopsittacus arfaki arfaki (Mey.).}

Trichoglossus (Charmosyma) Arfaki A. B. Meyer, Verh. zool. bot. Ges. Wien, 1874, p. 37 (Arfak Mts.).

우 Lehuma, Arfak Peninsula, 7.vi.1928. "Iris greyish green. Bill black. Feet dark greyish green."

Weight $17 \mathrm{~g}$. Wing $76.5 \mathrm{~mm}$.

\section{Charmosyna papou papou (Scop.).}

Psittacus Papou Scopoli, Del. Florae et Faunae Insubr. p. 86 (1786-Ex Sonnerat, Voy. Nouv. Guinée, p. 175, pl. iii, New Guinea. As terra typica I fix Arfak).

Charmosyna papuensis (Gmelin) 1788, et auctorum.

(I have with great reluctance adopted the name papou, instead of the usual papuensis, but if we accept priority we must do it to the bitter end, and the sooner alterations are introduced, the better.)

2 ㅇ mountains near Siwi, 1 ô, 2 ㅇ Lehuma, 6 ô mountains near Ditschi. "Iris yellowish red or reddish yellow, bill red, feet orange." The sexes are almost alike in colour.

Weight 74-91 g.

\section{Charmosyna josephinae josephinae (Finsch).}

T'richoglossus josephinae Finsch, Attr Soc. Ital. Sc. Nat. xv, p. 427, pl. 7 우 (1873-The type is a female without locality in the Turati collection, Milan, but A. B. Meyer collected specimens near Passim, east coast of Berau Peninsula, and on the Arfak Mts. As terra typica the Arfak Mts. should be regarded).

9 ํํํ ad., 2 juv. mountains at Siwi, $ᄋ$ mountains near Ditschi, $q$ Ninei, ô Lehuma. "Iris yellow."

Weight 58-74 g.

259. Charmosyna josephinae cyclopum subsp. nov.

Both sexes differ from $C h$. josephinae josephinae in the absence of the large dull black patch on the abdomen and of the greyish blue patch on the head, in front of the black nape; the feathers of the abdomen are blackish at the base, but red on at least the distal half, so that one can say that the black patch is indicated, but it is not developed. Instead of the bluish sincipital patch there are only a few partially greyish blue feathers. Wings ô 120-121, once 124 , once 125 , ㅇ $120 \mathrm{~mm}$.

Type: $\widehat{o}$ ad. Cyclops Mountains, 5.ix.1928. No. 2163 Ernst Mayr coll.

5 ô, 2 ㅇ Cyclops Mountains. "Iris reddish, yellowish, yellow-red. Bill orange-red. Feet orange.

Weight 68-75 g."

I am not acquainted from sight with Neumann's $C h$. josephinae sepikiana 
(Verh. Orn. Ges. Bayern, xv, 2, p. 235, 1922), but Stresemann tells me that it has an extended blackish patch on the abdomen. Neumann says it differs from $C h$. jos. josephinae in having the feathers on the crown dirty grey instead of lilac; they must therefore be still duller than in cyclopum, though they are not really "lilac" in the Arfak josephinae. Ch. josephinae sepikiana must therefore look more like $C h . j$. josephinae than like $C h . j$. cyclopum.

\section{[Charmosynopsis pulchella pulchella (Gray).}

Mr. Shaw Mayer sent an adult female from about 2,000 m. altitude on the Arfak Mountains, shot August 1928. Papuan name "pomiki." Wing $95 \mathrm{~mm}$.

The distribution of this form is very interesting. We find it in Arfak, in the southern Snow Mountains, Mount Goliath, in S.E. New Guinea, and in the Huon or Kai Peninsula in N.E. New Guinea, while in the Cyclops Mountains another form is found. It seems thus, that the plains of the Rouffaer, van Daalen and Idenburg Rivers, which form the Ambernoh or Mamberano River, are a great dividing zone. $C h$. pulchella has not been recorded from the Sepik River, nor so far from the Astrolabe Bay country.]

\section{Charmosynopsis pulchella rothschildi subsp. nov.}

7 ô, 4 ㅇ, 1 ㅇ juv. Cyclops Mountains, September 1928. "Iris brown, reddish brown, yellowish. Bill orange. Feet orange."

Weight $36-40 \mathrm{~g}$. The males are brighter in colour, especially the yellow short streaks on the breast, and in the females there is a greenish yellow patch at the side of the rump, which in the male is red.

The young has the breast green with dull yellow tips, but without any yellow streaks.

This excellent new subspecies differs from $C$. pulchella pulchella from Arfak and S.E. New Guinea and N.E. New Guinea, which seem to be all the same, in having a wide green band across the upper breast in which are the yellow streaklets. In the females it reaches right across, in the adult males it is more or less restricted to a green patch, the sides of the latter being red with green or greenish bases to the feathers. In the young this green band is very wide. The black nuchal patch begins at the posterior edge of the eye, while in $C . p$. pulchella it does not touch the eye. On the rump is in the centre only an indication or no blue-grey patch, which in $C . p$. pulchella it is very distinct. Wings of 97-101, ㅇ 95-97 mm., thus a little larger than C. p. pulchella.

This form is named in honour of Lord Rothschild, who first called my attention to the presence of the green band.

Type: + Cyclops Mountains, 12.ix.1928. No. 2300 Ernst Mayr coll.

\section{Neopsittacus musschenbroekii musschenbroekii (Schleg.).}

Nanodes Musschenbroekii Schlegel (ex Rosenberg), Ned. Trjdschr. Dierk. iv, p. 34 (1873-Arfak Peninsula).

ô mountains near Ditschi, 2 ô, 1 q Kofo (Anggi gidji), 11 . vi. 1928, q Lehuma. "Iris red, in one adult male yellowish brown, in a juvenile bird yellow. Bill yellow, feet grey."

Weight $39 \cdot 5-51$ g."

Mr. Shaw Mayer sent a + from 2,000 m., Arfak Mountains, iris yellow, Papuan name " borida." 
N. m. major Neum. from S.E. New Guinea is indeed larger. (N. pullicauda Hart. 1896 ("N. muschenbrocki alpinus" Grant 1914) is not known to occur in the Arfak Peninsula.)

\section{Opopsitta desmarestii desmarestii (Desm.).}

Psittacus Desmarestii Desmarest, Dict. Sci. Nat. (ed. Levrault), xxxix, p. 89 (1826-Dorey Harbour, Arfak Peninsula).

(It was Desmarest who first fully described this bird under his own name, saying that Lesson and Garnot dedicated it to him, but Garnot's first description did not appear till 1828.)

(It seems to me that not a single one of the characters given by Dr. van Oort for his $O$. desmarestii intermedius from Fak Fak is constant. We have specimens from Arfak which absolutely agree with others from Kapaur, which is practically the same as Skru and Fak-fak; I therefore think that intermedius cannot be accepted as anything but a synonym.)

ơㅇํ Siwi, 11.v.1928.

Weight $96,97 \mathrm{~g}$. Iris brown.

\section{Probosciger aterrimus goliath (Kuhl).}

Psittacus Goliath Kuhl, Consp. Psittacorum, p. 92 (1820 - "In India orientali," terra typica restricta Onin, Stresemann 1923. This must of course be accepted, though it would have been better to say Berau Peninsula, from where Kuhl's type more likely had come ').

2 ô Momi.

\section{Probosciger aterrimus stenolophus (van Oort).}

Microglossus aterrimus stenolophus van Oort, Notes Leyden Mus. xxxiii, p. 240 (1911-Humboldt Bay).

ô ad. Hollandia.

This subspecies differs from $P . a$. goliath in the narrower and more blackish crest feathers.

$P$. aterrimus aterrimus (Gm.) inhabits the Cape York Peninsula.

$P$. aterrimus alecto (Temm.), Waigiu, Gemien, Salwatty and Misol.

$P$. aterrimus goliath (Kuhl), Berau and Onin Peninsulas, Snow Mountains and S.E. New Guinea.

$P$. aterrimus intermedius (Schleg.), the Aru Islands.

P. aterrimus stenolophus (van Oort), Ambernoh River to N.E. New Guinea.

\section{Kakatoe galerita triton (Temm.).}

Psittacus triton Temminck, Coup d’oil gén. possessions néerland. dans l'Inde archipel. iii, p. 405 (1849-Aiduma Island, Triton Bay).

ㅇ near Manokwari, 우 Momi.

\section{Micropsitta pusio beccarii (Salvad.).}

Nasiterna beccarii Salvadori, Ann. Mus. Civ. Genova, viii, p. 396 (1876-Wairoro or Wairor on the east coast of the Berau Peninsula).

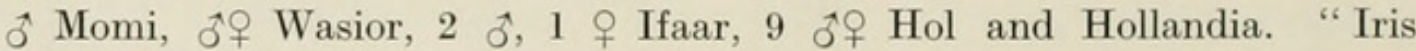
brown or grey-brown."

These birds seem to me to be all indistinguishable, and I do not believe now that salvadorii (Rothschild \& Hartert), Nov. ZooL. 1901, Ambernoh River, is 
different from beccarii! We had not seen proper beccarii when we described salvadorii. The yellow band above the eyes is an individual character, not always distinct.

267. Micropsitta bruijnii bruijnii (Salvad.).

Nasiterna bruijnii Salvadori, Ann. Mus. Civ. Genova, vii, pp. 715, 753, 907 (1875-Arfak Mts.).

ôㅇํ Wondiwoi, July 1928.

Weight ô $14 \cdot 5$, 우 $12 \cdot 5 \mathrm{~g}$.

\section{Loriculus aurantiifrons batavorum Stres.}

Loriculus aurantiifrons batavorum Stresemann, Journ.f. Orn. 1913, p. 602 (Snow Mts., etc.).

1 ㅇ Hollandia, 10. viii. 1928.

Weight $14 \mathrm{~g}$. Wing $68 \mathrm{~mm}$.

Loriculus aurantiifrons aurantiifrons was described and is only known from Misol.

\section{Psittacella modesta modesta Schleg.}

Psitacella ${ }^{1}$ modesta Schlegel, Nederl. Tijdschr. Dierk. iv, p. 36 (1873-Arfak Peninsula).

1 ô Lehuma, Arfak Peninsula, 4.vi.1928. "Iris light red. Bill whitish grey. Feet grey."

Weight $39 \mathrm{~g}$.

Psittacella modesta collaris Ogilvie-Grant 1914, from the Snow Mountains (Utakwa River) and Mount Goliath is distinguishable, but the yellow collar on the nape is more or less irregular and not always well defined in the males as well as the females. The sides of the head and the throat in collaris are more rufous brownish than in $P$. m. modesta, which is a very rare bird in collections.

\section{Psittacella brehmii brehmii Schleg.}

Psittacella Brehmii Schlegel, Ned. Tijdschr. Dierk. iv, p. 35 (1873-Arfak Peninsula).

$\hat{\jmath}+$ mountains near Ditschi, ô Kofo (Anggi gidji), 4 ㅇa., 1 ô ad., 2 juv., 1 marked $\delta$, 1 \& Lehuma. " Iris yellow-brown, in one ô 'pink.',"

Weight 102 to $116 \mathrm{~g}$.

The young have the breast green with narrow dull yellow eross-bars, but without black cross-markings. In the of the yellow patch on the sides of the neck is beginning, a few yellow feathers making their appearance. Shaw Meyer sent specimens from Anggi Gita, 2,000 m.

[The following forms of Psittacella brehmii are known :

Psittacella brehmii brehmii Schleg. Arfak Peninsula.

Psittacella brehmii bürgersi Rchw. Mandated Territory N.E. New Guinea.

Psittacella brehmii pallida Mey. S.E. New Guinea.

Psittacella brehmii intermixta subsp. nov.

This form was called by us P. brehmii brehmii, but the differences were stated. Ogilvie-Grant called them pallida. Now that we have a sufficient series from the Arfak Peninsula one can unhesitatingly say that the series from the Snow Mountains and Mount Goliath are neither. The males are underneath more yellowish green, upper throat and sides of head are paler, the light bars on the upperside are more yellowish, less grass-green. The female has the

1 Quoted " Psittacus " by Rothschild \& Hartert, and later on by Mathews! Under the description no locality is given, but on p. 35 it is clearly stated that the two new forms of Psittacella were obtained in the Arfak (Berau) Peninsula. 
abdomen more yellowish green, sides of head and upper throat paler, bars on back much yellower.

They differ strikingly from $P . b$. pallida by the much darker and browner head and throat and larger size. P. b. bürgersi has the back much more green, less yellowish, a different brown on the head, and is smaller! The bill much smaller !

Type of $P$. $b$. intermixta ô ad. Mount Goliath, 30.i.1911.

No. 5249 A. S. Meek coll. In Tring Museum.

Psittacella lorentzi Oort from the Wichmann and Orange Mountains seems to be related to $P$. picta, and may be a subspecies of the latter; perhaps the type was not adult ?]

\section{Geoffroyus geoffroyi jobiensis Salvad.}

Geoffroyus jobiensis Salvadori, Ann. Mus. Civ. Genova, x, p. 30 (1877-Jobi Island).

? Geoffroyus personatus minor Neumann, Verh. Orn. Ges. Bayern, xv, 2, p. 235 (1922-"Deutsch Neuguinea, westlich des Sattelberges und das nördliche Holländisch-Neuguinea bis zum Mamberano." Type Jagei, tributary of Ramu River).

3 ô, 2 우 Hol and Hollandia, July, August and October. October specimens in very worn plumage, female with greatly enlarged ovary.

Weight 150 and $180 \mathrm{~g}$. Wings ô $162,169,165$, ㅇ $165,166 \mathrm{~mm}$.

Our series do not bear out Neumann's contention that specimens from North New Guinea are constantly smaller. Wings of Jobi specimens ô 166, 168,174 , of specimens from the Mandated Territory $156-170 \mathrm{~mm}$.

\section{Geoffroyus geoffroyi ${ }^{1}$ pucherani Souancé.}

Geoffroyus Pucherani Souancé, Rev. et Mag. Zool.1856, p. 218 (Ex Hombron et Jacquinot et Pucheran, from specimens collected at Triton Bay !).

$\widehat{乛}$ 우 Momi, east coast of Berau (Arfak) Peninsula, end of June.

\section{Geoffroyus simplex simplex (Mey.).}

Pionias simplex A. B. Meyer, Verh. k. zool.-bot. Ges. Wien, lxx, p. 29 (1874-Arfak Mts. 3,500 feet).

ㅇ ad. mountains near Ditschi, 5.vi.1928.

Weight $165 \mathrm{~g}$. Wing $159 \mathrm{~mm}$.

Unfortunately no males were sent. It seems that Neumann's G. simplex bürgersi (1922) is separable, but I should like to examine a series of males from Arfak to confirm the distinctness.

\section{Eclectus roratus pectoralis (Müll.).}

(Larius (sic) Boddaert, Tabl. Pl. Enl. 1783).

Psittacus pectoralis P. L. S. Müller, Natursyst. Suppl. p. 78 (1776 - "China," errore, New Guinea terra typica subst. Ex Buffon-rectius Montbeillard-Hist. Nat. Ois. vii, p. 93, and Daubenton's $\mathrm{Pl}$. Enl. 514, ô).

1 ô, 3 우 Siwi, Arfak Peninsula, 3 ô Ifaar, near Sentani Lakes, 3 ô, 2 우 Hol.

The iris (in the various subspecies) seems to vary! As a rule it is no doubt whitish yellow or yellowish white in the females, and brown or dark red in the

${ }^{1}$ In " Austral Avian Record," ii, pp. 105, 106, Mathews somewhat violently accuses a brother ornithologist of having accepted personatus Shaw as the name of the Timor form, saying that it was published in 1812, while Psittacus geoffroyi Bechstein appeared in 1811. In the Systema Avium Australasianarum (sic), p. 324, however, he says that $P$. personatus Shaw was also published in 1811 ! Is it therefore necessary to accept geoffroyi instead of personatus ? 
males. We have, however, in the collection specimens of females, in which the iris is also, sometimes, though rarely, marked as brown by reliable collectors.

A 9 shot Siwi $17 . v$. has the whole underside in full moult, breast partially naked. A of from Ifaar shows partial " albinism," some of the upper wingcoverts and one of the inner secondaries being yellow, while some of the rectrices are varied with yellow and red.

\section{Psittrichas fulgidus (Less.).}

(Dasyptitus pesqueti auct. !)

Psittacus pesqueti Lesson, Illustr. pl. i (1831-No locality).

1 ô mountains near Siwi, 1 ô, 2 ㅇ Wondiwoi.

The males have a small red patch behind the eye, besides being larger than the females.

Weights of 800 and 840 , $q 650$ and $800 \mathrm{~g}$.

It is one of the horrors of modern strict priority nomenclature that our old friend Dasyptilus pesqueti must be called Psittrichas fulgidus !

\section{Alisterus amboinensis dorsalis (Quoy et Gaim.).}

Psittacus (Platycercus) dorsalis Quoy et Gaimard, Voy. Astrolabe, Zool. i, p. 234, Oiseaux, pl. xxi. fig. 3 (1830-Dorey, Arfak Peninsula).

$4 \hat{\jmath}, 5$ † Siwi, Arfak Mountains, 1 ô Ninei, 1 $q$ Momi, 1 ㅇ above Wasior, east coast of Arfak Peninsula, 25. viii., primaries moulting.

There is no appreciable difference of the sexes!

The iris of adults is red, of younger birds apparently yellowish red.

\section{Alisterus amboinensis moszkowskii (Rehw.).}

Aprosmictus mozkowskii ${ }^{1}$ Reichenow, Orn. Monatsber. 1911, p. 82 (Taua).

16 ô 0 Hol and Hollandia, 1 ô Cyclops Mountains. The interscapular region is blue in the males, dark green in the females and younger birds, both sexes have the light green streak on the inner upper wing-coverts. Iris red in both sexes. The females also have green, not blue, feathers in the sides of the chest.

I agree with Neumann's views in Verh. vi. Intern. Orn. Kongress. pp. 436-453, viz. that it is advisable to treat all forms of Alisterus from Peling (east of Celebes) and Sula Island to Australia (cf. Neumann, p. 438) as subspecies of one species. Within this assemblage a number of groups can of course be formed, as in most cases where a species is composed of numerous subspecies. Neumann's clear explanations are of the greatest use for the understanding of this genus.

\section{Ninox theomacha (Bp.).}

ơ juv. Siwi, Arfak, 15.v.1928. " "Iris golden yellow."

The upperside is darker, more slaty than in adults, the still downy (mesoptile) underside earthy brown.

${ }^{1}$ Not " mosskowensis" as Mathews spells it! It is not unimportant to mention such slips, as they are copied by people not having access to literature. 


\section{Ninox dimorpha (Salvad.).}

q Siwi, Arfak, 4.v.1928. " Iris yellow with black," bill " dark grey," feet "yellow."

This long-tailed species looks " hawk-like" and should probably be placed in another genus. Perhaps a generic name is already available for it.

\section{Haliastur indus girrenera (Vieill.).}

Haliaetus Girrenera Vieillot \& Oudart, Gal. Oils i, pl. 10 and p. 31 (partim) (1825-India and Australia. Restricted typical locality Australia! Cf. Nov. Zool. xxi, 1914, p. 210 !!).

$\hat{o}$ ad. Siwi, $q$ ad. Ifaar, $\hat{o}$ ad. $q$ juv. Hollandia. The old birds have of course no trace of black shafts on the white underside!

\section{Henicopernis longicauda (Garnot).}

Falco longicaudus Garnot, Voy. Coquille, Zool. pl. 10 (1828), p. 588 (1829-Woods of New Guinea, type from Dorey).

ㅇ ad. Siwi, Arfak, 15.v.1928. "Iris golden yellow. Bill black, base and cere pale flesh-colour. Feet whitish green."

Weight $730 \mathrm{~g}$. Outer primaries moulting.

\section{Accipiter novaehollandiae leucosomus (Sharpe).}

Astur novae-hollandiae Subsp. a. leucosomus Sharpe, Cat. B. Brit. Mus. i, p. 119 (1874-New Guinea).

Common garb (etorques), above brownish slate-colour, clearer slate in the male, underside rufous-cinnamon: $\hat{\jmath}$ jun. Siwi, $\hat{\jmath}+\underline{t}$ ad. Ifaar. White garb (leucosomus): \& Hollandia, 4.viii.1928. Iris yellow in both colorations. ㅇ Weight $320,375 \mathrm{~g}$. 19.ix. female with greatly enlarged eggs.

\section{Accipiter poliocephalus Gray.}

Accipiter poliocephalus Gray, Proc. Zool. Soc. London, 1858, p. 170 (Aru Islands).

Urospizias spilothorax Salvadori, Ann. Mus. Civ. Genova, vii, p. 900 (1876-Arfak Mts., New Guinea).

2 ô Siwi, 1 ô Ifaar. " Iris dark brown. Cere orange." Dragon-flies in stomach.

Spilothorax was described, because of its striped breast and browner upperside, but Salvadori soon corrected his mistake. It has been erroneously cited as a subspecies by Mathews.

Acc. haplochrous of New Caledonia has been quoted as a subspecies of poliocephalus by Stresemann, but I do not agree, for, apart from the colourdifferences, the lores are covered with black feathers, while they are almost naked in poliocephalus, and the bill of haplochrous is more elongated. Moreover, the young are very different, being patched and cross-barried in haplochrous, white with narrow shaft-stripes in poliocephalus.

\section{Ieracidea berigora novaeguineae Mey.}

Hieracidea novaeguineae A. B. Meyer, Journ.f. Orn. 1894, p. 89 ("Nova Guinea orientali." Specimens from Astrolabebay, Finschhafen, Stephansort, Constantinhafen were examined).

ㅇ Hollandia, 9.x.1928. Ovary small.

Weight $500 \mathrm{~g}$.

"Iris brown. Bill bluish white. Feet dirty pale grey." Wing 345, but moulting. 
The distinctive characters of the subspecies novaeguineae are still somewhat doubtful, as the colour is so variable, but it seems that the Papuan race is smaller! While the Hollandia specimen and those from the Sattelberg, Vulcan and Dampier Islands belong to the dark form, those from the Angabunga and Aroa Rivers belong to the light rufous form; a female (Nyman coll.) from Simbang (near Sattelberg, on the coast) in worn plumage, 8.viii.1899, is somewhat intermediate, but clearly also of the rufous form. We have thus dark blackish and rufous ones from the same area.

In Australia the rufous and light birds are common in Western Australia and seem to be predominating and almost exclusive in the interior of Australia, very rare in Eastern and Southern Australia. They are therefore generally looked upon as subspecies, though their status as geographical representatives requires further investigation.

\section{Egretta intermedia plumifera (Gould).}

Herodias plumiferus Gould, Proc. Zool. Soc. London, 1847 ("New South Wales ").

수우 ad. Ifaar, 21.ix.1928.

Weight $460,480 \mathrm{~g}$.

This Heron, though known from Australia, the Torres Straits, Aru Islands, Salwatti, Mafor, and some of the Moluccan Islands, has only once been recorded from New Guinea: Bangs and Peters, Bull. Mus. Comp. Zool. 67, p. 424, two unsexed from the Merauke swamps.

\section{Egretta garzetta nigripes (Temm.).}

Ardea nigripes Temminck, Man, d'Orn., second ed., iv, p. 376 (1840-Sunda Islands).

ô ad. Ifaar, 29.ix. 1928.

Weight $425 \mathrm{~g}$.

\section{Nycticorax caledonicus hilli Math.}

Nycticorax caledonicus hilli Mathews, Nov. Zool. xviii, p. 233 (1912-N.W. Australia. This is virtually a nomen nudum, being compared with another Australian bird. Full description B. Austr. iii, p. 459).

ㅇ Momi, ô Ifaar, ㅇ juv. Ifaar.

$N$. c. hilli is much paler on the upperside and has pure white ornamental head-plumes.

\section{Dupetor flavicollis gouldi (Bp.).}

Ardetta gouldi Bonaparte, Consp. Gen. Av. ii, p. 132 (1855-Australia).

2 ô, 2 q Ifaar. Large testes in September. Iris yellow.

Weight $350,355,355,360 \mathrm{~g}$.

\section{Phalacrocorax sulcirostris (Brandt).}

수우 Ifaar, 18.ix . 1928.

Weight ơ 960 , ㅇ $700 \mathrm{~g}$.

"Iris bottle-green, bill and feet blackish." The female has a smaller bill and smaller dimensions generally. 
290. Phalacrocorax melanoleucus melanoleucus (Vieill.).

Hydrocorax melanoleucus Vieillot, Nouv. Dict. d'Hist. Nat., nouv. éd., viii, p. 88 (1817-).

ô ad. Ifaar, 21.ix.1928.

Weight $700 \mathrm{~g}$.

(Phal. melanoleucus brevirostris Gould from New Zealand is a subspecies with black breast and abdomen in adults.)

\section{Anas superciliosa pelewensis Hartl. \& Finsch.}

[Anas superciliosa Gmelin, Syst. Nat. i, 2, p. 537 (1789-New Zealand !).]

Anas superciliosa var. pelewensis Hartlaub \& Finsch, Proc. Zool. Soc. London, 1872, p. 108 (Pelew Islands).

2 ô ad. Ifaar, September 1928.

Cf. Rothschild \& Hartert, Nov. ZooL. 1905, p. 248, and Nov. ZooL. 1914, p. 283.

The wings measure 227 and $230 \mathrm{~mm}$.

These birds agree with Pacific Islands specimens, having a buff throat, dark upperside with brown edges to the feathers, and short wings. I can therefore only call them $A$. s. pelewensis.

\section{2. (?) Anas superciliosa rogersi Math.}

Anas superciliosa rogersi Mathews, Austral Avian Record, i, 2, p. 33 (1912-Augusta, S.W. Australia).

ô ad. Kofo (Anggi gidji, Arfak Peninsula), 11.vi.1928. "Testes large."

This bird has wings of $260 \mathrm{~mm}$. It is therefore too large for pelewensis and agrees with Australian specimens. Australian birds are not larger than New Zealand ones, as Mathews suggested, but one can say that their throats are buff, less white, in fresh specimens, and that, as a rule, the edges to the underside are less whitish, and often the upper surface, too, a little darker.

I cannot follow Mathews, who makes rogersi inhabit "Western and Northern Australia and New Guinea," and lets A. s. superciliosa inhabit "New Zealand and East Australia, Tonga and Fiji Islands." If $A . s$. rogersi is separable it inhabits the whole of Australia, A. s. superciliosa New Zealand. Anas superciliosa pelewensis is of course not found on the Pelew Islands only!

The Kofo specimen might be an exceptionally large example, but not only are the wings longer, but the bill also-in fact the whole bird. Weight 950, the two Ifaar birds each $700 \mathrm{~g}$. [According to native information this Duck breeds on the Anggi Lakes.-Mayr.]

Anas superciliosa oustaleti Salvad. from Guam and Saipan is a very well marked subspecies of $A$. superciliosa.

\section{Tadorna radjah radjah (Garnot).}

Anas Radjah Garnot, Voy. Coqulle, Zool. livr. 8, pl. 49, p. 602 (1828-Buru!).

ô jun. Momi, 29.vi.1928.

Weight $800 \mathrm{~g}$.

\section{Podiceps ruficollis tricolor Gray.}

Podiceps (Sylbeocyclus) tricolor. J. R. Gray, Proc. Zool. Soc. London, 1860, p. 366 (1861-Ternate). ô ad. Ifaar, 28.ix.1928.

Weight $165 \mathrm{~g}$. 
295. Podiceps ruficollis novaehollandiae Stephens.

Podiceps novaehollandiae Stephens, in Shaw's Gen. Zool. xiii, p. 18 (1826-Australia, ex Latham).

우 Ifaar, 21 .ix . 1928.

Weight $165 \mathrm{~g}$.

This form is evidently a migrant from Australia.

296. Ptilinopus superbus superbus (Temm.).

Columba superba Temminck in Temminck \& Knip's Pigeons, p. 75, pl. 33 (1810 - "Otaheiti," errore, substituted terra typica: Halmaheira).

5 ô, 1 ㅇ juv. Siwi, 2 ô above Wasior, 1 우 Ditschi, 1 우 Cyclops Mountains, 25.vii.1928. Testes large, 31.viii.1928. Ovary enlarged. "Iris yellow."

Weight ô 114-150 g.

297. Ptilinopus coronulatus quadrigeminus (Mey.).

Ptilopus quadrigeminus A. B. Meyer, Ibis, 1890, p. 421 ("Constantine Harbour or its neighbourhood").

6 ô, 3 q Ifaar. "Iris ochre yellow. Feet red."

Weight 65-73 g. (Female laying 18.ix.1928.)

These birds are quadrigeminus, agreeing with specimens from Constantin Harbour, Stephansort and Vulean Island. They differ from geminus of Jobi and Takar by their slightly more bluish grey (not greenish) sides of the head, and the throat has a less defined and paler yellow middle line. The purple line between the crown and the yellow semi-circular line on the occiput is sometimes quite as distinct as in geminus and not a reliable character.

It is, therefore, this form which ranges to Humboldt Bay, not geminus.

298. Ptilinopus iozonus jobiensis (Schleg.).

Ptilopus humeralis jobiensis Schlegel, Mus. Pays-Bas, iv, Columbae, p. 16 (1873-Jobi).

$3 \hat{\jmath}, 2$ ㅇ Ifaar, September. Weight $75-100 \cdot 5$ g., the latter with large eggs (25.ix.1928). "Iris yellowish, ochre, red." The iris by other collectors has been described as orange-yellow, cadmium yellow, dull brownish yellow. On the other hand, the iris of $P$. iozonus iozonus from S.E. New Guinea is described as milk white, creamy white, light yellow, white! The most striking difference is of course the presence of a wide whitish apical bar on the rectrices in iozonus, which in jobiensis is not visible from above.

299. Ptilinopus ornatus gestroi Salvad. \& d'Alb.

Ptilinopus gestroi Salvadori \& d'Albertis, Ann. Mus. Civ. Genova, p. 834 (1875-Yule Island).

ô ad. with large testes Cyclops Mountains, 28. viii.1928.

Weight $200 \mathrm{~g}$. "Iris light reddish, feet dark red."

(The rare $P$. ornatus ornatus from Arfak was not obtained.)

\section{Ptilinopus aurantiifrons Gray.}

Ptilonopus aurantiifrons G. R. Gray, Proc. Zool. Soc. London, 1858, p. 185, pl. 137 (Aru Islands). Ptilopus aurantiifrons var. Novae-Guineae A. B. Meyer, Sitzungsber. $k$. Akad. Wien, xlix, p. 508

(1874 Passim, east coast of Berau Peninsula).

The differences seen in one female from Passim are purely individual, as shown by our series.

7 ํำ ad. Ifaar.

Weight $120-150 \mathrm{~g}$. 


\section{Ptilinopus pulchellus decorus Mad.}

Ptilopus decorus Madarász, Ann. Mus. Nat. Hungar. viii, p. 173 (1910-Near Erima and Friedrich Wilhelm Hafen, Astrolabebay).

옹 ovary with large yellowish eggs, Hollandia, 13.x.1928.

Weight $73 \mathrm{~g}$.

Though the whole breast is in bad condition, there can be, I think, no doubt that this specimen belongs to decorus, the male of which has distinct whitish tips to the more forked feathers of the breast, and paler abdomen and under tail-coverts. Madarász's statement that decorus has a larger bill is not correct. His plate, though not a careful drawing, but an impressionistic rough sketch, shows the differences well, except that the breast has not whitish tips to the feathers, but dark grey patches.

We had P. p. decorus from Takar and Konstantinhafen.

\section{Ptilinopus pulchellus pulchellus (Temm.).}

Columba pulchella Temminck, Pl. Col. 564 (1835-Lobo Bay, Sal, Müller coll.).

ô Manokwari, 11.iv.1928. ôे Momi, 25.vi.1928.

Weight $66 \cdot 5 \mathrm{~g}$.

\section{Ptilinopus rivolii bellus Scl.}

Ptilonopus bellus Sclater, Proc. Zool. Soc. London, 1873, p. 696, pl. Ivii (Hatam, Arfak Mts.).

Nobody can doubt that bellus is a subspecies of the rivolii group, as we now accept subspecies. This common bird was met with in the mountains in all regions.

$2 \hat{\delta}$ ad., 1 ㅇ mountains near Siwi, $\hat{\sigma}$ juv. above Ditschi, $2 \hat{\sigma}$ Lehuma, $1 \hat{\jmath}$ Wasior, 4 ô, 1 q Wondiwoi, 1 ô Wasior, 4 ô Cyclops Mountains. On 8.ix.1928 a male flew off a nest containing one egg.

\section{Ptilinopus pectoralis pectoralis (Wagl.).}

Columba pectoralis Wagler, Iris, 1829, p. 740 ("Habitat in sylvis densis Novae-Guineae"-as he says "Habitat cum praecedente").

2 ô Cyclops Mountains. "Iris yellow, outer pink ring. Bill yellow. Feet red."

Weight $111 \mathrm{~g}$.

\section{Megaloprepia magnifica puella (Less.).}

Columba puella Lesson, Bull. Univ. Sc. Nat. x, p. 400 (1827- "Port Praslin and Dorey." Port Praslin being on New Ireland is of course a mistake, the typical locality is therefore Dorey in the Arfak Peninsula).

2 q ad. Momi, east coast of Arfak Peninsula.

Wings $155,161.5 \mathrm{~mm}$.

306. Megaloprepia magnifica interposita subsp. nov.

1 ô ad. Wasior, Wandammen Peninsula, 21.vii.1928. "Iris pink. Bill yellowish. Feet yellowish green."

Weight 200 g. No. 1615 Mayr coll. Type of interposita!

This form has the underside of the tail as black as in $M . m$. puella from Arfak, but the vent is brighter yellow, the under tail-coverts as a rule more 
yellowish, yellow spots on wing-coverts and scapulars larger, size larger. Wings ô $173,171,168,170,168,165$, ㅇ $163,157.5 \mathrm{~mm}$.

Habitat: Wandammen (type), Etna Bay, Setekwa River, Mimika River, Lower Snow Mountains. This new subspecies stands between puella and septentrionalis and has an intermediate geographical position.

\section{Megaloprepia magnifica septentrionalis Mey.}

Megaloprepia poliura septentrionalis A. B. Meyer, Abh. Ber. k. Zool. Mus. Dresden, 1892-93, No. 3 , p. 25 (1893- "Konstantinhafen (Astrolabe-Bay), Kafu and Jobi ").

3 ô, 1 ㅇ Hollandia, 2.viii., 31 . vii., 10.x. 1928.

Weight " 185-250 g." " Iris red, edge of eyelid yellowish green."

This form is very closely allied to $M$. $m$. poliura Salvad. from S.E. New Guinea, and the colour of the underside of the tail and of the under wing-coverts is the same, though variable, but the vent is more yellow, not so olivaceousyellow; it differs from $M . m$. puella by the underside of the tail being more greyish, less black, and the anal region is generally somewhat between that of puella and poliura, but often as in puella. Wings ô 162-167, "ㅇ " $164 \mathrm{~mm}$.

\section{Ducula rufigaster (Quoy et Gaim.).}

Columba rufigaster Quoy et Gaimard, Voy. Astrolabe, Zool. i, p. 245, pl. xxvii (1830-Dorey, now Manokwari).

ô ad. Momi, ô ad. Cyclops Mountains, 2.ix.1928. Testes large.

\section{Ducula chalconota (Salvad.).}

Carpophaga chalconota Salvadori, Ann. Mus. Civ. Genova, vi, p. 87 (1874-Hatam, Arfak Mts.).

2 ô, 1 우 mountains near Ditschi, 11.vi.1928, ㅅ Wondiwoi, 10.vii.1928.

\section{Ducula zoeae (Desm.).}

Columba zoeae Desmarest, Dict. Sci. Nat., ed. Levrault, xl, p. 314 (1826), and Lesson, Voy. Coquille Zool., Atlas, pl. 39 (1826-Dorey, Arfak Peninsula).

$\widehat{o}$ ad. Siwi and Ifaar.

Weight 555 and $600 \mathrm{~g}$.

\section{Columba vitiensis halmaheira (Bp.).}

Janthoenas halmaheira Bonaparte, Consp. Gen. Av. ii, p. 44 (1855 - ex ins. Gilolo, Ceram). Janthoenas albigularis, id. loc. cit., nec Compt. Rend. Acad. Paris, xxxix, p. 1077, 1854 !

ô ad. mountains near Siwi, 20.v.1928. "Weight 450 g. Iris ochreyellow. Bill base dark red, tip whitish. Feet red."

ㅇ juv. mountains near Ditschi.

\section{Columba (Gymnophaps) albertisii albertisii Salvad.}

Gymnophaps albertisii Slavadori, Ann. Mus. Civ. Genova, vi, p. 86 (1874-Andai, Arfak Peninsula). 3 ô ad., 3 + ad., 1 q juv. Siwi, + ad. Lehuma, ơ ad. Wondiwoi, $q$ Hollandia, ô Cyclops Mountains. "Iris red, coral-red. Feet dark red."

"Weight 220-280 g." 


\section{Macropygia amboinensis doreya Bp.}

Macropygia doreya Bonaparte, Consp. Gen. Av. ii, p. 57 (1855-New Guinea. Type undoubtedly from Dorey Harbour, from the Astrolabe Expedition).

2 ô ad., 2 ô juv., 3 오 Siwi, Ditschi and Manokwari, 1 우 Wondiwoi.

Weight $130,150 \mathrm{~g}$.

\section{Macropygia amboinensis cinereiceps Tristr.}

Macropygia cinereiceps Tristram, Ibis, 1889, p. 558 (Fergusson I., d'Entrecasteaux group).

$2 \hat{o}$ ad. Cyclops Mountains, August 1928. Testes large.

Weight $115,138 \mathrm{~g}$.

315. Macropygia nigrirostris Salvad.

Macropygia nigrirostris Salvadori, Ann. Mus. Civ. Genova, vii, p. 972 (1876-Arfak).

ㅇ Siwi, $\hat{\jmath} \hat{\jmath}$ Wasior and Ifaar.

(M. n. major Oort, Notes Leyden Mus. xxix, p. 174 (1908), from New Britain does not seem to differ at all! The characters described by van Oort seem to be individual.)

\section{Reinwardtoena reinwardtsi griseotincta Hart.}

Reinwardtoenas reinwardtsi griseotincta Hartert, Nov. Zool. iii, p. 18 (1896-Papua, type Mailu district, British New Guinea).

$\uparrow$ ad. mountains near Siwi, ô ad. Cyclops Mountains, ô ad. Ifaar. Testes, 12.ix.1928, large.

Weights $300,300,310$ g. " Bill base and cere red, tip dark grey."

317. Chalcophaps stephani stephani Jacq. \& Puch.

Chalcophaps stephani Jacquinot et Pucheran, Voy. Pôle Sud, Zool. iii, p. 119 (also pl. 28, fig. 2, under the name of "Chalcophaps d'Etienne") (1853 - "Nouvelle-Guinée, côte occidentale ").

ô Wasior, ㅇ Hollandia, 17.ix.1928, with large eggs, ㅇ Ifaar, 2.ix.1928, with fairly large eggs.

Weight 95, 103, $115 \mathrm{~g}$.

\section{Henicophaps albifrons albifrons Gray.}

Henicophaps albifrons G. R. Gray, Proc. Zool. Soc. London, 1861, p. 432 (Waigiu).

오 Momi, ô juv. Wasior, ㅇ Wondiwoi, 1 ô, 2 우 Hollandia.

Young birds have the forehead brownish, sides of head, neck and nape blackish, not deep chestnut brown, and the metallic patches on the wings smaller. Of apparently adult birds some have the forehead brownish rufous, others pure white, others again white with rufous tinge above the eyes or behind. According to the sexing of Dr. Mayr and other collectors the difference is not sexual.

[Rosenberg, Nat. Tijdschr. Ned. Indie, xxix, p. 143 (1866-Aru Is.) described "Rynchaenas Schlegeli." This name has always, if at all, been quoted as a synonym of Henicophaps albifrons. Mathews says that no locality was given and "restricts" the name to Waigiu. But he evidently did not look the quotation up; the whole article of Rosenberg is only on birds from the Aru and Key Islands, and on p. 145 he says clearly which species were from Aru and which from the Key Islands. The name schlegeli must therefore be used for the Aru form, if that is different. To me it seems to differ, the underside in 
our two specimens being grey or greyish, not vinous brown, and the beak is very long! Wings in a good series from New Guinea 182.5-202, in two from Aru Islands 202 and $211 \mathrm{~mm}$. long !]

\section{Gallicolumba beccarii beccarii (Salvad.).}

(Phlegoenas beccarii auct.)

Chalcophaps beccarii Salvadori, Ann. Mus. Civ. Genova, vii, p. 974 (1875-Arfak Mts.).

ㅇ Kofo (Anggi gidji), 12.vi.1928.

Weight $72 \mathrm{~g}$.

\section{Gallicolumba jobiensis jobiensis (Mey.).}

(Phlegoenas margarithae, Cat. B. Brit. Mus. and auct.)

Phlegoenas jobiensis A. B. Meyer, Mitth. Zool. Mus. Dresden, i, p. 10 (1875-Jobi Island; description of young bird).

ô juv., ㅇ ad. Wasior (Wandammen), 우 ad., ôㅇ juv. Ifaar, ô juv. Momi !

(Why is not $G$. kubaryi from the Carolines a subspecies of $G$. jobiensis (margarithae) ?)

321. Gallicolumba rufigula rufigula (Jacq. \& Puch.).

Peristera rufigula Jacquinot \& Pucheran, Voy. Pôle Sud iii, p. 118 (1845-Name given to the Péristère a gorge rousse on plate xxvii, fig. 1 , therefore not nomen nudum ! No locality, but New Guinea and apparently from the Arfak Peninsula, which might therefore be taken as the terra typica).

1 ad. Momi, 1 ㅇ juv. Momi, ํㅜㅇ ad. Siwi, ô ad. Hol.

Ogilvie-Grant was apparently right in calling specimens from the Lower Snow Mountains (Setekwa River) Gall. rufigula helviventris-unless specimens from those are an intermediate form, but our Aru material is insufficient, and helviventris was described from Aru. Ogilvie-Grant was, however, wrong in saying that the presence of grey behind the eye is due to non-age, for some of our adult specimens have more grey there than young ones. Young birds have a vinous brown breast and the edges to the wing-coverts pale rufous instead of grey. The question is whether helviventris is really different from rufigula! Grant has already quoted both from the lower hills of the Snow Mountains, rufigula from the Mimika and Wataikwa Rivers, helviventris from the Setekwa River. Both forms seem to occur in S.E. New Guinea! From the Wanggar River, 15 miles from its mouth, south of Geelvink Bay, 600 feet high, Pratt Bros. sent typical rufigula. A specimen from the Sattelberg bought from Foerster, probably collected by Keysser, has hardly any grey behind the eyes and agrees better with helviventris. If the two forms are separable, their distribution requires elucidation!

\section{Trugon terrestris terrestris Gray.}

Trugon terrestris G. R. Gray, Gen. Birds, iii, Appendix, p. 24 (1849-Ex "Trugon terrestre," a French name, of Hombron et Jacquinot. If the name terrestris is adopted as of Gray, then the generic term must also be accepted!) (West coast of New Guinea, which means Arfak Peninsula).

ㅇ ad. Momi, Arfak Peninsula, ôㅇ Hollandia 18.x. and 4.viii.1928. Testes and ovary large! "Iris red. Bill grey, forepart white. Feet whitish or pale pink." 
"Weight ồ 370 , 우 305,340 g."

The female is like the male, only smaller. The Trugon terrestris leucopareia Meyer, from S.E. New Guinea, is a well-marked subspecies.

\section{Otidiphaps nobilis nobilis Gould.}

Otidiphaps nobilis Gould, Ann. \& Mag. Nat. Hist. ser. 4, vol. v, p. 62 (1870-No locality, but probably came from New Guinea, and I select as terra typica Arfak).

† ad. above Wasior, Wandammen Peninsula, 26.vii.1928.

Males are much larger than females. The wing of this female measures only $193 \mathrm{~mm}$.

\section{Goura victoria beccarii Salvad.}

Goura beccarii Salvadori, Ann. Mus. Civ. Genova, viii, p. 405 (1876-Humboldt Bay).

ô ad. Ifaar, 20.ix.1928. "Iris reddish. Bill blackish grey. Feet dirty red." Testes large.

Weight $2,750 \mathrm{~g}$. Wing $385 \mathrm{~mm}$.

Unfortunately only this one specimen was collected. It has the upperside dark, in fact as dark as in typical Jobi specimens, but is very much larger. Our skins from Konstantinhafen (Astrolabe Bay), collected by Kubary, and those from Stephansort (close by, Astrolabe Bay), collected by Nyman, are much lighter, but not much larger, wings about $385-390 \mathrm{~mm}$. They seem to belong to G. $v$. huonensis, which is said to be restricted to the "Kai Halbinsel " (Huon Gulf region), but may extend to Astrolabe Bay.

[The bird was in this vicinity extremely rare, and I could, in spite of all my effort, only get this one specimen.--E. Mayr.]

\section{Charadrius apricarius fulvus Gm.}

Charadrius fulvus Gmelin, Syst. Nat. i, 2, p. 687 (1789-Tahiti).

ㅇ Manokwari, 8.iv., ㅇ Kaju pulu, 15.x., Hollandia, 15.x.1928.

It will be logical, according to present conception, to regard $C h$. dominicus and fulvus as subspecies of apricarius. I suggested this in 1920 (Vög. pal. Fauna, ii, p. 1551), but did not take the plunge.

\section{Charadrius dubius jerdoni (Legge).}

Aegialitis jerdoni Legge, Proc. Zool. Soc. London, 1880, p. 39 (Ceylon and India).

ㅇ ad. Ifaar, 18.ix.1928 in moult. "Iris brown, eyelids golden yellow, bill black, base of lower mandible light, feet pale flesh-colour."

Weight $34 \mathrm{~g}$.

327. Tringa (Heteractitis) incana brevipes (Vieill.).

Totanus brevipes Vieillot, Nouv. Dict. d'Hist. Nat. (nouv. éd.), vi, p. 410 (1816-No locality, but type from Timor, teste Pucheran).

ㅇ Kaju pulu near Hollandia, 15.x.1928.

\section{Tringa hypoleucos L.}

Tringa Hypoleucos Linnaeus, Syst. Nat. ed. x, 1, p. 149 (1758 - "Europa." Terra typica restricta Sweden).

2 ô Ifaar, 19.ix.1928 ơ Kaju pulu near Hollandia, 15. viii. 1928. 
329. Numenius phaeopus variegatus (Scop.).

Tantalus variegatus Scopoli, Del. Flor. et Faun. Insubr., fase. ii, p. 92 (1786-Luzon. Ex Sonnerat, Voy. Nouv. Guinée, pl. 48, p. 85).

1 ad. Ifaar, 18.ix. 1928.

\section{Irediparra gallinacea novaeguineae (Rams.).}

Parra novae-guineae Ramsay, Proc. Linn. Soc. N.S. Wales, iii, p. 298 (1878-25 miles west of Port Moresby, in S.E. New Guinea).

10 q ad., 7 od., 2 juv. Ifaar, September 1928. Iris of the adult $\delta$ and $q$ " cream-colour, yellowish brown, pale brown. Distal half of bill black, basal half and 'comb' reddish or orange, in males paler, more yellowish. Feet greenish grey." Weight of males 76-92, of females 151-175 g.

It is well known that the females are considerably larger than the males. Wing o $120-122$, $+138-147 \mathrm{~mm}$. This great difference in size in all parts of the body is very striking and not generally known. All eastern forms of Parridae show a difference in size between the sexes, but though we have no explanation, there must be biological peculiarities which explain this.

There are three subspecies of this species :

\section{Irediparra gallinacea gallinacea (Temminck) 1828 .}

First described from Menado, Celebes. Tail black with a steely gloss, upper surface a somewhat glossy olive-brown, nape metallic blue-black, extending to the interscapular region.

This form is not rare on Celebes, and seems to extend to Mindanao, South Borneo, certain Moluccas, and the Key Islands. A single male specimen from Buru (Heinrich Kühn coll.) seems to be of the Australian form, and other Moluccan birds I have not examined nor any from Timor. An Aru Islands female is very dark and seems to belong to the New Guinea form ! I have not been able to examine Mindanao examples, from where Mearns recorded it, nor Bornean ones, but Grabowski sent a skin and four clutches of eggs from S.E. Borneo.

\section{Irediparra gallinacea novaehollandiae (Salvad.) 1882.}

Described conditionally from two specimens collected in North Australia by D'Albertis !

This subspecies is strikingly paler, a sort of pale bronzy, almost greyish brown on the upper wing-coverts, secondaries, scapular and interscapulium. The rectrices are usually much less blackish, with a bronzy gloss, which is not present on the tail of the Celebes form. This was rather emphasized, but first pointed out by Mathews. That the black breast-band is less wide seems to be due to preparation, and is not a distinguishing character.

This form is, as far as I know, peculiar to Australia, where it occurs in N.W. Australia, the Northern Territory, Queensland and New South Wales, the names rothschildi and melvillensis of Mathews being synonyms of novaehollandiae.

\section{Irediparra gallinacea novaeguineae (Rams.) 1878.}

This form is the darkest. It is almost entirely black on the upperside. The deep blue-black of the nape extends over the interscapulium to the rump and upper tail-coverts. The tail is black with a slight bronzy gloss, and almost as deep in colour as in I. g. gallinacea. The scapulars and inner secondaries are 
a very deep oil-green, the upper wing-coverts are sooty black, with little or no gloss, the breast deep black, in all subspecies the feathers of the upper breast white at base.

This subspecies is found in S.E. New Guinea, on the Setekwa River, on the Sepik River, near Ifaar, on Misol, and apparently on the Aru Islands.

On September 20th female with large eggs. The "comb" of the female is red-yellowish, of the males yellow-reddish, much less bright.

\section{Chlidonias leucopareia fluviatilis (Gould).}

Hydrochelidon fluviatilis Gould, Proc. Zool. Soc. for 1842, p. 140 (1843- "Interior of New South Wales").

$1 \hat{0}, 2$ ㅇa. in breeding plumage, 2 in non-breeding garb, Ifaar, 18. and 28.ix. 1928.

This is the form inhabiting Australia, New Guinea, Moluccas to Celebes, C. $l$. rogersi Math. not being separable.

\section{Sterna bergii pelecanoides King.}

Sterna pelecanoides King, Survey Intertrop. coasts Austr. ii, p. 422 (1826-Torres Straits).

ô Kaju pulu near Hollandia, 15.x.1928.

\section{Sterna sumatrana sumatrana Raffl.}

Sterna Sumatrana Raffles, Trans. Linn. Soc. London, xiii, p. 329 (1822-Sumatra).

3 ô, 2 ㅇ ad. Hol September 1928, ㅇ 12 . viii. 1928, eggs ready for laying.

Several eggs were taken end of September on small coral islands outside Hol which agree with a series of eggs from other localities.

\section{Anous minutus minutus Boie.}

(Anous leucocapillus auct.)

Anous minutus Boie, Isis, 1844, p. 188 (Australia, terra typica restricted by Mathews to "Raine Island " !).

10 ô, 8 ㅇ Kaju Pulu near Hollandia, 15.x.1928.

Probably after breeding, sexual organs being small and plumage much worn.

(As Boie's description is not very fixative it would have been better to leave matters unchanged, viz. to quote Anous minutus of Boie with a query, and to employ the name leucocapillas, as was done by Salvadori, Saunders and others. As, however, the specific term minutus has been employed recently. elsewhere, I do not propose to change it again.)

[ $\mathrm{I}$ heard there is a large breeding colony of this bird on Commerson Island (Sae), N.E. of Ninigo, and the birds probably came from there.-E. Mayr.]

\section{Hypotaenidia philippensis subsp. nov. ? ?}

3 ô, 1 ㅇ Ifaar, September 1928. " Iris red."

Weight 185, 210, 225, $240 \mathrm{~g}$. Wings ô $147 \cdot 5,148,152$, 우 $146.5 \mathrm{~mm}$.

This interesting species is separable into quite a number of local subspecies, but I find it difficult to name the Ifaar birds. Their swollen testes and ovary seem to indicate that they are not astray nor winter visitors from Australia, 
moreover they differ from numerous Australian specimens in their general darker colouration of the upperside and of the rufous parts, as well as heavier bills. When the Tring Museum received a fine series from Witu (French Islands) north of New Britain I called them lesouefi, but not without hesitation, and I explained at length the differences (Nov. ZooL. xxxiii, p. 172, 1926). I find now that these birds cannot really be united with lesouefi! The latter was described from New Hanover, and Mathews said he "associated with it birds from New Britain." Though lesouefi is quite a good form, it is not correct to unite with it New Britain ones, the latter being like the Witu form !

The Witu form differs from H. p. lesouefi Math. in the more or less unspotted lower back, rump, upper tail-coverts and rectrices, all these parts being heavily spotted with white in lesouefi. Also the crown is more brown, not so chestnutred as in lesouefi. Wings ô $143-147,+9136,138 \mathrm{~mm}$. Type : ô ad. Witu Island (French group), 30.vi.1925. No. 10.354, Albert F. Eichhorn coll. I call this form

\section{Hypotaenidia philippensis meyeri subsp. nov.}

in honour of Father Otto Meyer, who has done so much for the knowledge of New Britain and the neighbouring small islands.

The specimens from Ifaar are so much like the $H . p$. meyeri that I refrain from separating them, though it must be said that the upperside is more frequently and heavier spotted. I wish to await more material before deciding if the Ifaar specimens can be separated from the Witu (and New Britain) form. I refrain from saying anything again about single specimens from other parts of New Guinea: one from the south coast of Geelvink Bay, July 1920, one from the Giriarin River, S.E. New Guinea, 5.x.1907, and one from the China Strait, Boboli, 19.viii. 1922.

These three birds have the rufous portion of the remiges lighter than in lesouefi and meyeri, more as in australis, and differ from each other.

I have seen the type of $H . p$. admiralitatis Stres. 1929, but have no specimens to compare; this form is near to lesouefi.

\section{Rallus pectoralis mayri subsp. nov.}

3 ô ad., 3 ㅇ ad., 2 ô juv., 1 ㅇ juv. Kofo, Anggi Gidji, Arfak Mountains, June 1928. "Iris brown, yellowish-brown. Bill reddish, culmen and tip blackish or black. Feet dark grey."

Weight 91-102 g. Wings ô 104-107, ㅇ 101-104 mm.

This new subspecies differs from $R$. pectoralis pectoralis Temm. ${ }^{1}$ The top of the head looks much more uniform, not being vinous chestnut with black centres to the feathers, but dull chestnut with dull blackish brown centres; the whole back is less bright, the edges to the feathers being darker, the sides of the hind-neck are less bright chestnut.

The bill is longer! As females have a shorter bill than males, males must be compared with males, females with females. Bill ô $38,38,39$, ㅇ $34 \cdot 5,35$, $36 \mathrm{~mm}$.

Type: ̊ ad. Kofo (Anggi gidji), 13.vi.1928. No. 1124 Ernst Mayr coll.

1 This is the oldest name of the species, not brachypus. Temminck (1831) described a specimen with unknown locality. Mathews says "New South Wales," meaning that he restricted the typical locality to N.S. Wales, not that it was described from there. 
The young birds are darker, crown uniform blackish, flanks dark greyish brown with a few dull whitish spots, but no white bars!

The occurrence of this large form of Rallus pectoralis in North New Guinea is of particular interest. Except the very much smaller, red-headed and rednaped Hypotaenidia pectoralis alberti Rothsch. \& Hart. from the Upper Angabunga River, in elevations of 6-8,000 feet (Nov. ZooL. xiv, p. 451), no form of this species has been known in New Guinea so far. They are evidently mountain birds in Papua.

Rails are altogether difficult but most interesting birds. Rallus pectoralis exsul Hart. from Flores seems to be still unique in collections.

\section{Porzana (Poliolimnas) cinerea subsp.}

There is one of ad. Ifaar, 30.ix. 1928.

Weight $60 \mathrm{~g}$. Wing $95 \mathrm{~mm}$.

The review of subspecies given by Stresemann in Nov. ZooL. xxi, 1914, pp. 53-55, is quite out of date, and mine in Nov. Zool. xxxi, 1924, p. 264, is now not quite complete. Mathews has discovered that Bonaparte's nude name minima was published by Schlegel, Mus. Pays-Bas, Ralli, p. 34, 1865, with locality, Outanata (where it was collected by S. Müller), and measurements : wing 3 pouces 3 lignes, which is $86 \mathrm{~mm}$. The wing of our Ifaar bird, however, measures $95 \mathrm{~mm}$. Also three specimens from Batjan, collected by John Waterstradt, have wings of $95-96 \mathrm{~mm}$. In colour they are like the Ifaar bird, though the latter is clearer whitish on the underside, a difference, however, which requires confirmation by a series. The crown of the three Batjan birds is very black, in most others, all over the range, it is more greyish, but one from Ceram, collected by Stresemann, has also a black head. In fresh plumage there are greyish edges to the feathers of the crown, which wear off in time.

Birds from Buru are smaller, wings $84-93 \mathrm{~mm}$. The terra typica is Buru, not Key Islands, as quoted by Mathews in the Systema Avium, 1927.

The Ifaar specimen cannot at present be separated, in fact any further subdivision would at the moment be hazardous.

\section{Porzana tabuensis (Gm.) subsp.}

Rallus tabuensis Gmelin, Syst. Nat. i, 2, p. 717 (1789- "Habitat in Tonga-tabu, Tahiti et insulis vicinis," ex Latham "Tabuan Rail").

10 ad., 3 juv. from Kofo (Anggi gidji), mid June. "Iris red. Bill black. Feet reddish or red." Weight $38 \cdot 5-45$ g. Several specimens are marked as having very large testes, so I suppose these birds were breeding about the Anggi Lakes, and they may be numerous on swamps in many places in New Guinea. So far as I know the species has only once been recorded from Papua, viz. 1 우 collected by Fenichel at Bongu, Astrolabe Bay, 29.viii.1892. Stresemann calls it an "Irrgast," but it may just as well be at home and sedentary near the Astrolabe Bay.

The collecting of swamp birds has hitherto been much neglected in New Guinea.

(Mathews' list of these Rails in his "Systema Avium," i, p. 92. is useless. It is unexplainable why he makes Rallus tabuensis Gmelin a subspecies of the totally black Rallus nigra of Miller! His various subspecies from Australia 
are indistinguishable. I dare not at present to separate the New Guinea form. Generally specimens from the Pacific Islands are smaller, but not always, while Australian ones are much larger ! The wings c lour Kofo (Arfak) specimens are : ô 82-84, ㅇ 80-82 mm. Now Australian birds have wings of about $85-90 \mathrm{~mm}$. Their name would be Porzana tabuensis immaculata (Swains.) 1837.

Examples from the Pacific Islands have wings of often 80, 82, or not rarely under $80 \mathrm{~mm}$.! They would be the typical Porzana tabuensis tabuensis (Gm.).

The Papuan race would seem to be another subspecies intermediate in size. As it seems to have no name there is here an opportunity for a young (or old) man "rerum novarum cupidus " to give a name to a form which he might not have seen!

339. Gallinula tenebrosa neumanni subsp. nov.

2 ô, 4 ㅇ Ifaar, near Sentani Lakes, 18. to 29.ix.1928. "Iris greyish brown, in one dark brown. Bill : tip yellowish green to olivaceous green, base brown-red, frontal shield olive-brown in all specimens! Feet greyish green, front scutes of metatarsus tomato-red. Testes small, ovaries medium, in one female large !

Weight $290,310,310,310,370,370,370$ g."

This new form has the upperside quite without or only with an indication (in one specimen) of an olivaceous tinge. It is nearest to G. $t$. frontata Wall. (type from Buru!), but differs in being smaller (bill, shield, feet, wings!) and in the colour of the bill and frontal shield, which in frontata is blood-red with a yellow tip, and a bright vermilion frontal shield. Length of bill from end of frontal shield to tip ô $42-44 \cdot 7$, once 41 , ㅇ $40-43 \mathrm{~mm}$., wing $\hat{\text { ô }} 182,182$, ㅇ 163 , $172,173,174 \mathrm{~mm}$.

Type: 우 ad. Ifaar, 20.ix.1928. No. 2471 Mayr coll.

This most interesting new subspecies is named after Professor Oscar Neumann, who has for some time shown a special interest in Rallidae and has urged many collectors to pay special attention to this fascinating family.

There is no doubt that $G$. $t$. frontata and $G$. $t$. neumanni must be treated as subspecies of $G$. tenebrosa. These three forms agree in the absence of the white streaks on the sides of the body, which are present in all forms of Gallinula chloropus and they breed in Celebes and possibly in S. Borneo together with a form of $G$. chloropus.

I have not examined specimens from S.E. New Guinea, but from what Salvadori said in Orn. Pap. iii, pp. 279, 280, one most believe that the Moluccan form, or a very near ally, but not neumanni, is found in S.E. Papua. It is interesting to see that Salvadori ascribes to his $G$. frontata a "lievissima sfumatora olivastra " on the back and wings.

\section{Fulica atra australis Gould (?).}

ô ad. Kofo (Anggi gidji), 12.vi.1928. " Iris brown-red, bill bluish white." Weight $590 \mathrm{~g}$. Testes very large, bird not fat.

There can be little doubt that this Coot is Fulica atra australis (or one of its forms if, which I don't think, several are separable), but without a series it is not advisable to be absolutely certain about this. It would seem that the species nests in New Guinea, from the notes on Dr. Mayr's label.

As far as I know this species has not been recorded from New Guinea! 


\section{Megacrex inepta D'Alb. \& Salvad.}

Megacrex inepta D'Albertis \& Salvadori, Ann. Mus. Civ. Genova, xiv, p. 129 (1879-Fly River New Guinea); Bangs \& Peters, Mus. Comp. Zool. 67, p. 424 (1926-Digul River, north of Merauke); Ogilvie-Grant, Ibis Suppl. 1915, p. 288 (Setakwa River).

2 우 Hol, 10 . viii. 1928.

Weight 800 and $900 \mathrm{~g}$. Wings about 170 and $180 \mathrm{~mm}$., but much worn.

This rare bird is only known from the Fly, Digul and Setakwa Rivers and now was for the first time obtained on the north coast of the island.

\section{Gallinula (Amaurornis) olivacea frankii Schleg.}

Gallinula Frankii Schlegel, Notes Leyden Mus. i, p. 163 (1879-Berau Peninsula, New Guinea).

Cf. Nov. Zool. xxxiii, p. 172, 1926.

One unsexed Momi, 3.vii.1928, ํํ요 Ifaar, 30.ix.1928.

Weight 200, $205 \mathrm{~g}$.

It seems from our (not very large!) series from the Moluccas and New Guinea that the latter are darker grey on the underside, and a shade darker olive on the back. In fact the Papuan specimens are near $G$. olivacea nigrifrons Hart. from New Britain, Witu Island, Duke of York and New Hanover, also Bougainville, and stand between $G$. olivacea moluccana and nigrifrons. It is therefore desirable not to unite the Papuan examples with the typical Molucean birds.

From my notes in Nov. ZooL. 1926 it would appear that New Guinea specimens had " a small orange-coloured frontal shield," but it is only sometimes indicated, not distinctly developed as in the Australian Gallinula (Amaurornis) olivacea ruficrissa Gould.

\section{Eulabeornis tricolor tricolor (Gray).}

Rallina tricolor Gray, Proc. Zool. Soc. London, 1858, p. 188 (Aru Islands).

Eulabeornis tricolor grayi Mathews, B. Australia, i, p. 205 (1911-New Guinea).

Cf. Nov. Zool. xxii, 1915, p. 26 !

ô ad. Hollandia, 9.x.1928.

\section{Rallicula rubra mayri subsp. nov.}

This is another most interesting discovery! Though very different from rubra rubra and rubra forbesi, I eannot doubt that these representative forms should be considered to be subspecies of one and the same species. The male of $R$. rubra rubra has the whole upperside chestnut, that of $R$. rubra mayri has it of a darker chestnut, but the underside of both is almost alike, only a shade darker in mayri. The sides of the vent and under tail-coverts have black bars, sometimes (especially in rubra rubra) indistinct or wanting, on the sides of the belly generally accompanied by pale chestnut bars. The male of $R$. rubra forbesi has the whole upperside of the wings and a wide bar across the back black, upper and under tail-coverts barred with black, but rectrices without bars. Sides of vent with lighter and darker bars. The female of $R$. rubra rubra has the back, scapulars, inner secondaries, rump and upper tail-coverts black, covered with roundish buff to (on the back) almost whitish spots. In $R$. rubra forbesi these spots are less numerous and rump and upper tail-coverts are unspotted, while the upper tail-coverts have a few black bars. In the female 
of $R$. rubra mayri these parts are not black, but dark chestnut, the little spots are more reddish buff and more or less surrounded by black; rump and lower back unspotted, upper tail-coverts with black bars, rectrices, at least laterally, with blackish bars.

Type of Rallicula rubra mayri ㅇ ad. Cyclops Mountains, 6.ix.1928, with two eggs almost ready for expulsion! No. 2198 Ernst Mayr coll. "Iris greybrown, bill and feet pure black."

4 ô, 1 q Cyclops Mountains about 1,200 m., August and September.

Weight +119 , of $123,123,129 \mathrm{~g}$. Wings of $114-117$, ㅇ $110 \mathrm{~mm}$.

The inner webs of the primaries and under wing-coverts of all these forms have wide white bars on a black or blackish ground.

As the males from the Snow Mountains and from Arfak (terra typica of the name rubra!) do not differ, I have, like Lord Rothschild, no doubt that "Rallicula klossi" Ogilvie-Grant, Bull. B.O.C. xxxi, p. 104, and Ibis Supplement, 1915 , p. 290, and plate vii (not very good, colour too red), is the same as $R$. $r$. rubra, though the female of the latter was, until 1913, undescribed.

\section{Rallicula leucospila (Salvad.).}

Corethrura ? leucospila Salvadori, Ann. Mus. Civ. Genova, vii, p. 975 (1875-Arfak Mts.).

ô mountains near Siwi, 3.v. 1928.

Weight $125 \mathrm{~g}$.

ô Wondiwoi, Wandammen Peninsula, 17.vii. 1928.

Weight 114 g. " Iris chestnut. Bill and feet black."

This species, of which so far no subspecies are known, is rare in collections. The male has narrow white stripes, one on each web of the feathers of the back, the female roundish white spots; in both sexes the back is black.

346. Synoicus ypsilophorus saturatior subsp. nov.

3 oิ, 8 아., 1 ô pull. Ifaar, September 1928. Both sexes have the iris dark brown, bill black, feet greenish yellow and yellowish brown.

Weight ô $82-91$, ㅇ $92-128 \mathrm{~g}$.

The females of this north coast form are much darker than females of plumbeus on the upperside, far less rufous brown, more olivaceous brown, the black spots larger, the creamy white shaft lines usually narrower, the underside generally not so yellowish, duller. The males are very much like the males of $S$. ypsilophorus plumbeus, but more saturated on the upperside, the grey on the feathers of the back being more blackish, the underside more and darker greyish. Wings ô 59-61, ㅇ 60-64 mm.

Considering that we have for comparison with the fine series from Ifaar an equally good one from S.E. New Guinea and a large series from various parts of Australia, I had to name the Ifaar form, the species having never been known from the north coast region, but only from S.E. Papua and thence up to the Astrolabebay. It was, however, with some reluctance that I named the new form, for the following reasons : While the majority of specimens are distinguishable, a few specimens turn up in most places which are practically or quite indistinguishable from individuals of other subspecies. Examples: Two females shot by Mr. Fullerton Smith, jun. near Maslow, New Zealand, in 1919, where Australian birds have been introduced and are thriving well, are like females 
of S. ypisolophorus saturatior, only being a faint shade more rufescent, but just as dark.—A female from the Upper Aroa River, collected by Meek, 12 . xii. 1904 (No. B. 105), is utterly different from typical S. y. plumbeus females, and is like light clay-brown females of the Australian S. y. australis !- Single females of the generally quite different S. $y$. raalteni from Letti, Timor and Alor are as dark as and partially darker than females of S. y. plumbeus and have the large black spots on the upperside like S. y. saturatior!- What do these variations mean? Can they be just individual varieties, can they be throw-backs to ancestral forms, or can the specimens be migrants from the habitats of other races or influenced by immigration? The latter seems to be the most unlikely explanation.

The following subspecies are obvious :

1. Synoicus ypsilophorus ypsilophorus Bose. 1792.

Tasmania. Like S. y. australis, but longer wings. Apparently sometimes darker.

\section{Synoicus ypsilophorus australis (Lath.) 1801.}

Australia.

Possibly the Cape York form, S. y. queenslandicus Math. 1912, and the north and north-west form, S. $y$. cervinus Gould 1865, are separable, but I cannot now go into that question.

\section{Synoicus ypsilophorus plumbeus Salvad. 1894.}

While the females are somewhat similar to those of australis, but much darker, with finer markings above and below, the males are very different, being plumbeous grey, with brown edges to the feathers of the underside, and brown markings on the upper surface. An exceptionally dark male was shot at Kumusi.

For an exceptional female from the Upper Aroa River see above. Males very rare in collections !

\section{Synoicus ypsilophorus saturatior Hart.}

Ifaar near Sentani Lakes, Humboldt Bay region. Only three males known.

5. Synoicus ypsilophorus raalteni Müll. 1842.

Timor, Flores, Letti, Kisser, Alor, Moa, Wetter.

Typical males are quite different from the former subspecies, being rufous with grey centres to the feathers, and the breast is lighter or darker rufous, always variable. Some (few) females are like those of $S . y$. plumbeus.

\section{Synoicus ypsilophorus pallidior Hart. 1897.}

Savu and Sumba._-Very much paler than raalteni.

(Female No. 2423, Ifaar, 17.ix.1928, has the greater part of the breast snow white ; otherwise it is quite normal.)

Type of S. y. saturatior 우 Ifaar, 17.ix.1928. Ernst Mayr coll. No. 2394. The eggs on the ovary very large. 
Cf. Rothschild \& Hartert, Nov. Zool. xiv, 1907, p. 447 ; Mathews, Austral. Avian Record, i, 5, p. 125 (about the name ypsilophorus)! The generic name remains Synoicus according to the International Rules of Nomenclature, for Synoicum is not Synoicus!

An egg of Synoicus ypsilophorus saturatior was taken from the oviduct at Ifaar. It is spotless greenish white, seen through the hole against the light it is light sea-green. It measures $29 \cdot 6 \times 23 \cdot 6 \mathrm{~mm}$.

\section{Megapodius reinwardt reinwardt Dumont.}

Megapodius Reinwardt Dumont, Dict. Sci. Nat. (édition Levrault), xxix, p. $416{ }^{1}$ (1823 - "Amboina " errore! Teste Schlegel Lombok !).

Megapodius Duperreyi Lesson et Garnier, Bull. Soc. Nat. viii, p. 113 (1826-Dorey).

ऽ우 Momi, 25.vi.1928. " "Iris yellow," error, the iris being brown. "Feet red-yellow."

Weight $810,860 \mathrm{~g}$.

\section{Megapodius reinwardt decollatus Oust.}

Megapodius decollatus Oustalet, Bull. Assoc. Sc. France, xxi, p. 248 (1878-d'Urville Island, now

"Kairiru" (!) between Hollandia and Astrolabe Bay).

ऽ우 and one sex doubtful, Hol, 4.viii., 14.x.1928. Feet marked "greygreen," black in the skins.

These skins agree in size with a series from Jobi Island. The two known examples of affinis Meyer from Rubi (south coast of Geelvink Bay) are very much smaller, wings 200 and $202 \mathrm{~mm}$., while the Hollandia ones measure $\hat{\imath} 220,+219$, ? $227 \mathrm{~mm}$.

Formerly Lord Rothschild and myself have recorded Megapodius reinwardt reinwardt (under the name of $M$. duperreyi duperreyi) from Dampier and Vulean Islands, but this was erroneous. The form found on these islands is a blacklegged bird and appears to be decollatus. Examples from S.E. New Guinea (Bihagi, head of Mambare River, Meek coll.) are also black-legged, and their wings, measuring 225-235 mm., seem to be a bigger race, huonensis Stres. 1922, described from the "Kai Peninsula," where Finschhafen and the Sattelberg are.

\section{Talegallus cuvieri Less.}

Talegallus cuvieri Lesson, Voyage Coquille, Atlas, Atlas, pl. 38 (1828-Dorey).

ㅇ ad. Momi, 25.vi.1928. " Iris yellow. Bill red. Feet yellowish red."

Weight $1,785 \mathrm{~g}$.

\section{Talegallus jobiensis jobiensis Mey.}

Talegallus jobiensis A. B. Meyer, Sitzungsber. Ak. Wiss. Wien, lxix, p. 74 (1874-Jobi).

1 pull., 3 ô ad., 1 ㅇ ad., 1 ? Hollandia, 3.-8. viii.1928. " Iris dark brown. Bill dirty red. Feet red. Weight 1,610 g. Hoden fast hühnereigross."

Cf. Nov. ZooL. July 1901, p. 139. I ean only repeat what Lord Rothschild and I said then, viz. that T. jobiensis longicaudus is a somewhat poor subspecies. The colour is the same in both, also the amount of chestnut on the neck is individually, not geographically, variable.

\footnotetext{
1 Not 146 as quoted by others !
} 


\section{Aepypodius arfakianus (Salvad.).}

Talegallus arfakianus Salvadori, Ann. Mus. Civ. ix, pp. 333, 334 (1877-Arfak Mts.).

† Siwi, 3 ô, 1,+ 1 ô pull. Cyclops Mountains August and September. "Iris pale yellowish grey or greyish green. Bill blackish grey. Bare skin on neck whitish blue with darker blue markings. Feet greenish yellow-grey."

Weight $1,350,1,530,1,525 \mathrm{~g}$.

There is, in adult birds, a fleshy comb-like crest, and a fold and short wattle in front of the bare neck. Four eggs were sent from Siwi 22.v. and Ditschi 1.vi.1928. The eggs have rather a thin shell and are of a glossless somewhat rough-grained white, measuring $91 \times 60,94.5 \times 62.5,88 \times 58 \mathrm{~mm}$. (one broken). They agree perfectly with specimens collected on the Hydrographer Mountains by Albert Eichhorn, 26.ii.1918, and measuring $95 \times 61,91 \times 61 \cdot 5$, $89.5 \times 61$ and $95.8 \times 59.5 \mathrm{~mm}$.

In the Catalogue of Eggs in the British Museum these eggs are not described. Nehrkorn in the Katalog der Eiersammlung, ii Auflage, p. 7, describes eggs from the Aroa River as those of Aepypodius as dark brownish-yellow, but they were the eggs of a Megapodius, the measurements $(81 \times 52 \mathrm{~mm}$.) also being too small. Unfortunately there are many other errors in that "Katalog."

\section{Casuarius unappendiculatus rufotinctus Rothsch.}

Casuarius unappendiculatus rufotinctus Rothschild, Trans. Zool. Soc. London, xv, part 5, p. 137 (1900-No locality).

Hol, August 1928, one adult male and one young, about two-thirds grown.

Lord Rothschild has no doubt whatever, and there is indeed no reason to doubt, though the colours are not recorded on the labels, that this is the C. unapp. rufotinctus, first described without exact locality, later on received from the " north coast," which, though vague, was apparently correct, this meaning the northern coast between the Humboldt Bay and Geelvink Bay. 


\section{$2 \mathrm{BHL}$ Biodiversity Heritage Library}

Hartert, Ernst. 1930. "III. List of the birds collected by Ernst Mayr." Novitates zoologicae : a journal of zoology in connection with the Tring Museum 36, 27-128. https://doi.org/10.5962/bhl.part.10108.

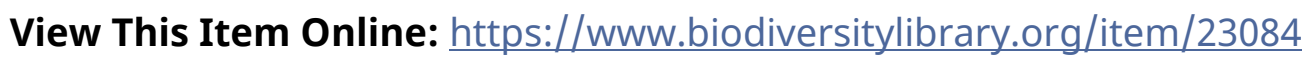

DOI: https://doi.org/10.5962/bhl.part.10108

Permalink: https://www.biodiversitylibrary.org/partpdf/10108

\section{Holding Institution}

Natural History Museum Library, London

\section{Sponsored by}

Natural History Museum Library, London

\section{Copyright \& Reuse}

Copyright Status: In copyright. Digitized with the permission of the rights holder.

Rights Holder: The Trustees of the Natural History Museum, London

License: http://creativecommons.org/licenses/by-nc-sa/4.0/

Rights: http://biodiversitylibrary.org/permissions

This document was created from content at the Biodiversity Heritage Library, the world's largest open access digital library for biodiversity literature and archives. Visit BHL at https://www.biodiversitylibrary.org. 